Editores

$$
\begin{aligned}
& \text { José Miguel Carmen Cesibel } \\
& \text { Túnez- Costa- Valdiviezo } \\
& \text { Lóper Sáncher }
\end{aligned}
$$

Prólogo/Belén Puebla-Martínez

\author{
Comunicación \\ Organizacional \\ en entornos online
}

Gestión, actores y recursos

Cuadernos Artesanos de Comunicación / 149

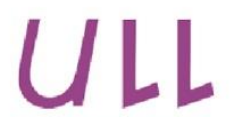

Universidad de La Laguna

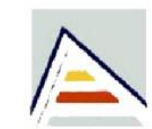

Universitat d'Alacant Universidad de Alicante
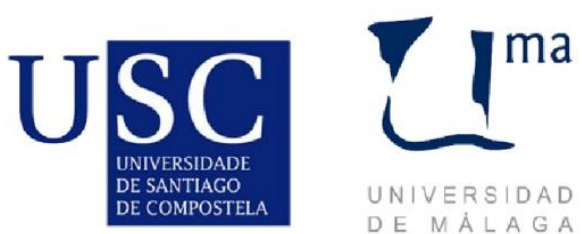

UNIVERSIDAD

DE M $\dot{A} L A G A$

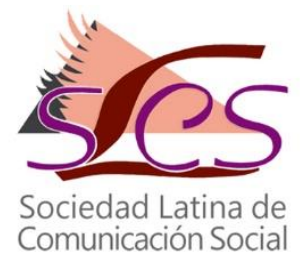


Cuadernos Artesanos de Comunicación / 149

Coordinador editorial: José Manuel de Pablos - jpablos@ull.edu.es

Comité Científico

Presidencia: José Luis Piñuel Raigada (UCM)

Secretaría: Milena Trenta

- Octavio Islas (Unversidad de los Hemisferios, Ecuador)

- Francisco Campos Freire (Universidad de Santiago de Compostela)

- José Cisneros (Benemérita Universidad Autónoma de Puebla, BUAP)

- Bernardo Díaz Nosty (Universidad de Málaga, UMA)

- Carlos Elías (Universidad Carlos III de Madrid, UC3M)

- Paulina B. Emanuelli (Universidad Nacional de Córdoba, UNC)

- José Luis González Esteban (Universitas Miguel Hernández de Elche, UMH)

- Marisa Humanes (Universidad Rey Juan Carlos, URJC)

- Juan José Igartua (Universidad de Salamanca, USAL)

- Xosé López (Universidad de Santiago de Compostela)

- Maricela López-Ornelas (Universidad Autónoma de Baja California, AUBC)

- Javier Marzal (Universidad Jaume I, UJI)

- José Antonio Meyer (Benemérita Universidad Autónoma de Puebla, BUAP)

- Ramón Reig (Universidad de Sevilla, US)

- Miquel Rodrigo Alsina (Universidad Pompeu Fabra, UPF)

- Xosé Soengas (Universidad de Santiago de Compostela)

- José Luis Terrón (Universidad Autónoma de Barcelona, UAB)

- Victoria Tur (Universidad de Alicante, UA)

- Miguel Vicente (Universidad de Valladolid, UVA)

- Ramón Zallo (Universidad del País Vasco, UPV-EHU)

- Núria Almiron (Universidad Pompeu Fabra, UPF)

Queda expresamente autorizada la reproducción total o parcial de los textos publicados en este libro, en cualquier formato o soporte imaginables, salvo por explícita voluntad en contra del autor o autora o en caso de ediciones con ánimo de lucro. Las publicaciones donde se incluyan textos de esta publicación serán ediciones no comerciales y han de estar igualmente acogidas a Creative Commons. Harán constar esta licencia y el carácter no venal de la publicación.

\section{(C) $\odot \Theta \Theta$} como las imágenes incluidas, si no se indica lo contrario, se encuentran bajo una Licencia Creative Commons Atribución-No Comercial-Sin Derivadas 3.0 Unported. Puede ver una copia de esta licencia en http://creativecommons.org/licenses/by-nc-nd/3.0/ Esto significa que Ud. es libre de reproducir y distribuir esta obra, siempre que cite la autoría, que no se use con fines comerciales o lucrativos y que no haga ninguna obra derivada. Si quiere hacer alguna de las cosas que aparecen como no permitidas, contacte con los coordinadores del libro o con el autor del capítulo correspondiente.

* La responsabilidad de cada texto es de su autor o autora. 
José Miguel Túñez-López, Carmen Costa-Sánchez

y Cesibel Valdiviezo/Editores

Prólogo Belén Puebla-Martínez

\section{Comunicación \\ Organizacional \\ en entornos online}

Gestión, actores y recursos

Cuadernos Artesanos de Comunicación /149

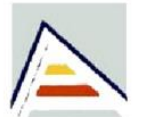

Universitat d'Alacant Universidad de Alicante
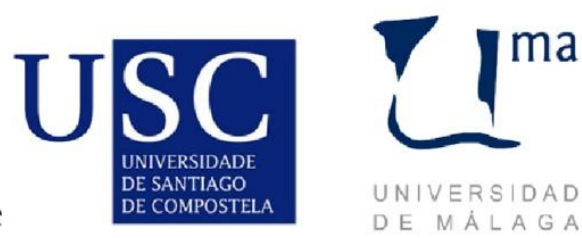

UNIVERSIDAD

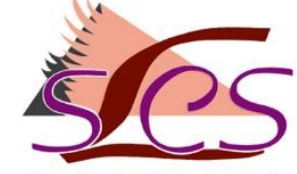

Sociedad Latina de Comunicación Social 
CAC 149 - Comunicación Organizacional en entornos online. Gestión, actores y recursos

Miguel Túñez-López, Carmen Costa-Sánchez y Cesibel Valdiviezo Editores | Precio social: 8,30€ | Precio en librería. 10,80€ |

Editores: Javier Herrero y Milena Trenta

Diseño: F. Drago

Ilustración de portada: Fragmento del cuadro "Mujer de Fuenteventura", de Vale (Bolonia).

Imprime y distribuye: F. Drago. Andocopias S. L.

c/ La Hornera, 41. La Laguna. Tenerife.

Teléfono: 922250554 | fotocopiasdrago@telefonica.net

Edita: Sociedad Latina de Comunicación Social - edición no venal - La Laguna (Tenerife), 2015 - Creative Commons http://www.revistalatinacs.org/14SLCS/portada2014.html

Descargar en pdf:

http://www.cuadernosartesanos.org/\#149

Protocolo de envío de manuscritos:

http://www.cuadernosartesanos.org/protocolo.html

ISBN: 978-84-17314-07-1

TF-1073-2018

DOI: $\underline{10.4185 / \operatorname{cac} 149}$ 


\title{
Comunicación Organizacional en entornos online. Gestión, actores y recursos
}

\author{
José Miguel Túñez-López, Carmen Costa-Sánchez \\ y Cesibel Valdiviezo (Editores)
}

\section{Resumen}

Las nuevas tecnologías y todo lo que conlleva el campo digital evolucionan de manera permanente y hace que las organizaciones se reinventen cada día. Por tanto, la comunicación organizacional en éstos entornos online debe también adaptarse, liderada a la cabeza por quienes gestionan la comunicación, considerando las transformaciones de los recursos que se requiere, pero especialmente, tomando en cuenta que son los públicos los que también exigen a las organizaciones de una comunicación inmediata, veraz, oportuna y de doble vía.

Cabe entonces un momento de reflexión del material que a continuación presentamos, fruto de la participación que se realizó en el IX Congreso de Latina de Comunicación, pero con un análisis más profundo y ampliado.

Si le apasiona la comunicación, estos textos aportarán a ampliar su visión respecto a la gestión de la comunicación en las organizaciones y de manera concreta visionará nuevas experiencias que están empezando a desarrollar las organizaciones desde la comunicación.

Palabras-claves: comunicación organizacional, entornos online, gestión de la comunicación, actores de la comunicación, recursos online.

\section{Forma de citar este libro}

Túñez-López, M., Costa-Sánchez, C. y Valdiviezo, C. (Eds.), (2018).

Comunicación Organizacional en entornos online. Gestión, actores y recursos.

Cuadernos Artesanos de Comunicación, no 149. La Laguna

(Tenerife): Latina 


\section{Índice}

Prólogo

Belén Puebla-Martíner

1. Adprosumidores, medios sociales, vídeo online y Comunicación Corporativa. Tendencias inmediatas

Carmen Costa-Sánchez, Miguel Túñez-López.

2. Gestión de stakeholders: un enfoque comunicacional

Valerie Báez, Diego Apolo, Gabriela Pasquel, Lizeth Pauker.

3. El capital social de las organizaciones en el contexto digital de la web 2.0

Roberto Alejandro López. Novelo, Raúl Santos Morales

4. Recursos para la gestión de la comunicación online

Verónica Altamirano, Fabiana Altamirano 75

5. Los prescriptores en la comunicación organizacional online: acciones, herramientas y estrategias

Francisco de Andrés Huertas, Sergio Mena Muñoz....

6. La comunicación como pieza clave en la gestión de públicos

Cesibel V aldiviezo, V anessa Duque

7. A Gestão das organizações emergentes: o impacto das redes sociais online nas Startups

Paula Cristina Ribeiro de Oliveira

Los autores y las autoras

El contenido de este libro ha sido sometido a un proceso de revisión de doble ciego por pares, semejante al sistema de revisión de un artículo científico para un journal. 


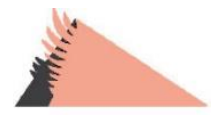 \\ Prólogo}

\section{Transformaciones e interacciones: una reflexión crítica de la Comunicación Organizacional en el contexto digital}

El libro que tiene en sus manos es un viaje por un aspecto de la comunicación, en este caso la organizacional, que despierta interés desde la primera página y sigue siendo estimulante hasta el final de la obra. Las diferentes visiones que ofrecen los autores demuestran un gran dominio del tema y una querencia por transmitirlo al lector de forma comprensible.

En el contexto digital que vive la sociedad del siglo XXI, la comunicación organizacional se halla en un proceso de continua transformación, en el que las interacciones con los públicos se convierten en pilares de un proceso comunicacional imprescindible para el éxito o fracaso de la empresa o la institución. De este modo aparecen nuevos agentes en el panorama organizacional y digital. Desde los adprosumidores, los prescriptores, los influencers... en definitiva, los stakeholders, hasta estrategias como el Lean Branding o el trabajo de los profesionales MarCom se vuelven fundamentales para que triunfe la comunicación organizacional. Todos ellos (que aparecen a lo largo de la obra) -públicos, estrategias, herramientas, profesionales- tienen un fin común: llegar a controlar, de la manera más eficaz, los movimientos globales, interactivos y participativos que confluyen en la actualidad entre las organizaciones y su relación con su público potencial.

En el primer capítulo Adprosumidores, medios sociales, vídeo online y Comunicación Corporativa. Tendencias inmediatas, dos de los coordinadores 
de este libro, Carmen Costa-Sánchez de la Universidade da Coruña, y José Miguel Túñez-López, de la Universidade de Santiago de Compostela, plantean los que consideran los tres pilares que actualmente sustentan la Comunicación Corporativa: los adprosumers (o nuevos públicos), los social media (con tendencias innovadoras en redes y plataformas participativas) y el vídeo online (con novedosos contenidos). Con estas bases principales lo que se pretende conseguir es la referencialidad como objetivo fundamental en un presente y futuro próximo en el entorno online. Todas las organizaciones necesitan generar credibilidad y confianza con sus públicos potenciales de tal forma que se forjen relaciones positivas entre ambos. Y, para ello, presentan un decálogo para una gestión eficaz de la comunicación que sirve de guía de buena praxis para las organizaciones.

Cabe destacar, sobremanera, el nuevo término acuñado de adprosumers, que se aleja del concepto de prosumers (productores y consumidores de contenidos). Para los autores, los públicos ahora tienen un naciente rol, el del adprosumers que responde a AD-anuncio, PRO-productor y SUMER-consumidor en tanto que compran, consumen y recomiendan productos simultáneamente generando tendencias y la tan ansiada referencialidad.

Con el título Gestión de stakeholders: un enfoque comunicacional los autores Valerie Báez de la Corte Nacional de Justicia del Ecuador; Diego Apolo de la Universidad Nacional Educación Ecuador y la Universidad de San Francisco de Quito; Gabriela Pasquel del Municipio del Distrito Metropolitano de Quito; y Lizeth Pauker de Yasuní Medios realizan una revisión exhaustiva de las bases, tanto teóricas como metodológicas, para la gestión de los stakeholders, de tal manera que se consigan los objetivos propuestos por las instituciones mediante estrategias que contribuyan a crear y asentar la reputación corporativa y la imagen de marca.

Los stakeholders son la pieza principal sobre la que construir estrategias. Es, por este motivo, por lo que este capítulo es realmente interesante, ya que hace un recorrido por las definiciones, las clasificaciones, las tipologías y las características más relevantes de estos actores o grupos 
de interés para la consolidación de su confianza por parte de las organizaciones.

Roberto Alejandro López Novelo y Raúl Santos Morales, de la Universidad Anáhuac, (México), presentan el tercer capítulo titulado El capital social de las organizaciones en el contexto digital de la web 2.0 en el que se realiza un repaso de las perspectivas clásicas y tecnológicas que ha supuesto para el capital social de empresas, asociaciones e instituciones el contexto digital en el que han de moverse para lograr una transformación social, tanto local como global. Estas organizaciones pretenden posicionarse e interaccionar consiguiendo una relación social con la utilización de la web 2.0 y 3.0 que generan vinculaciones con las personas y grupos de interés para dar paso a la dimensión estructural del capital social.

Por este motivo, es indispensable conocer las posibilidades que presenta Internet para que las organizaciones puedan involucrarse de manera estable y duradera con los stakeholders para alcanzar una comunicación eficiente y provechosa con propiedades bidireccionales y/o multidireccionales.

En el cuarto capítulo, Verónica Altamirano, de la Universidad Técnica Particular de Loja y Fabiana Altamirano, de la Universidade de Vigo, exponen los Recursos para la gestión de la comunicación online. Para las autoras estos recursos que presentan son básicos en la comunicación organizacional con sus potenciales consumidores en el momento actual. Se busca la participación global de su público objetivo. Los futuros compradores de un producto o usuarios de un servicio ya no se conforman con una comunicación unidireccional en el que ellos sean agentes pasivos. Buscan interactividad y bidireccionalidad que formen una actitud colaborativa con la organización de tú a tú.

La forma de conseguir que las organizaciones generen y consoliden una comunicación online eficaz y eficiente se puede alcanzar utilizando y sacando el máximo partido a los recursos presentados por las autoras. Desde sitios web interactivos con herramientas como el correo electrónico, los foros de discusión, los chats o las encuestas online; pasando por los social media dirigidos a una audiencia global, con fácil 
acceso, uso sencillo, actualizaciones instantáneas y elaboración colectiva de contenidos; hasta el uso de blogs, canales de microblogging como Twitter, las wikis, las redes para compartir fotografías como Flickr o Pinterest, o vídeos con la plataforma YouTube. Además de la utilización generalizada de las redes sociales, sean profesionales, específicas o generalistas. Conociendo todas estas herramientas las organizaciones tienen que decidir cuáles son las mejores para relacionarse de manera directa con su público, teniendo en cuenta sus peculiaridades.

Desde la Universidad Complutense de Madrid, los profesores Francisco de Andrés Huertas y Sergio Mena Muñoz presentan el capítulo Los prescriptores en la comunicación organizacional online: acciones, herramientas $y$ estrategias desarrollan un estado de la cuestión del panorama digital en la comunicación que llevan a cabo las organizaciones de todo tipo de tal forma que se analiza la tendencia en alza que tienen los mensajes comerciales e informativos en el entorno digital. Para ello, hacen una clara diferenciación entre los conceptos de influencer y prescriptor ya que "los influencers saben que son usados como herramienta de una marca para promocionarla sin caer en ningún conflicto ético al aceptar la regla del juego y abandonar (incluso) sus principios para trabajar para y por la marca. Sin embargo, un prescriptor ya es un líder de opinión por sus posicionamientos previos y si una marca decide apostar por su figura no se pretende ni se busca en ningún caso que abandone sus principios para amoldarse al mensaje deseado".

Se analizan tres estudios de caso de prescriptores altamente seguidos como son: Casey Neistat un reconocido youtuber estadounidense que, además, es director de cine y blogger, Banksy, artista callejero muy cotizado del que no se conoce completamente su identidad, lo que le permite actuar desde al anonimato y, por último, la Agencia Creativa \& Production Vimema, una agencia especializada en Internet que produce su propio contenido considerada como la que más impacto tiene en la red en España. En los tres casos se ha efectuado un estudio de las acciones, las herramientas y las estrategias para poder distinguir las tendencias presentes y prospectivas de la comunicación en el entorno digital. 
El capítulo sexto propone como tema La comunicación como pieza clave en la gestión de públicos y está firmado por otra de las coordinadoras de esta obra, Cesibel Valdiviezo, de la Universidad Técnica Particular de Loja, junto a Vanessa Duque, de la Universidad Nacional de Loja. Partiendo de la base de que para lograr un mejor posicionamiento y fidelización de la marca de una empresa es fundamental la comunicación integrada entre el marketing y la comunicación organizacional, las autoras plantean, en primer lugar, la evolución de los profesionales dedicados a fomentar y garantizar el éxito. De esta manera, se pasa del Director de Comunicación (DirCom) al MarCom, un experto que asume la responsabilidad de las comunicaciones institucional y mercadológica para alcanzar la integridad de la comunicación organizacional.

Una de las principales funciones del MarCom es generar un vínculo penetrante con sus diversos públicos: sea la fidelización de los públicos internos, como el buen posicionamiento con los externos. Por este motivo, las organizaciones se encuentran ante una nueva realidad corporativa para conocer estos grupos de interés. Este nuevo perfil de stakeholders está formado mayoritariamente por los Baby Boomers, la generación X y los millenials. Es obligación de la organización gestionar este talento humano para construir embajadores de la marca.

Por último, Paula Cristina Ribeiro de Oliveira, de la Universidade de Santiago de Compostela, expone A Gestão das organizações emergentes: o impacto das redes sociais online nas Startups, en el que profundiza en el estudio del marketing web como una herramienta eficaz para nuevas empresas debido a sus características principales: rapidez, facilidad de uso, gran alcance, transparencia, bajo coste y un alto grado de interactividad con sus usuarios para generar, a través de las redes sociales digitales, un incremento de ventas y ganancias.

Las empresas emergentes o startup buscan visibilidad a través de las redes sociales mediante una metodología Lean branding que ofrece unas condiciones excelsas para este tipo de organizaciones gracias a su habilidad de adaptación con ideas innovadoras y tecnológicas. El modelo Lean Startup es una estrategia empresarial que consigue la eficiencia de la organización aplicando un proceso de innovación 
específico para sus particularidades. Como afirma la autora "A Lean Startup é uma nova forma de olhar para o desenvolvimento de produtos inovadores que enfatizam a rápida interação da informação do cliente, uma grande visão e grande ambição, tudo ao mesmo tempo".

Como se ha podido comprobar, este libro es un compendio de diferentes enfoques que versan sobre la Comunicación Organizacional de tal modo que aclaran numerosas cuestiones y, a su vez, abren nuevos interrogantes de un tema muy profuso y de gran calado, tanto en el aspecto académico como en el profesional.

Belén Puebla-Martinez. Universidad Rey Juan Carlos

PARA CITAR: Puebla-Martínez, B. (2018). Transformaciones e interacciones: una reflexión crítica de la Comunicación Organizacional en el contexto digital. En Túñez-López, M., Costa-Sánchez, C. y Valdiviezo, C. (Eds.), (2018). Comunicación Organizacional en entornos online. Gestión, actores y recursos. Cuadernos Artesanos de Comunicación, no 149 (pp. 7-12). La Laguna (Tenerife): Latina. 


\title{
Adprosumidores, medios sociales, vídeo online y Comunicación Corporativa. Tendencias inmediatas
}

\author{
Carmen Costa-Sánchez \\ Universidade da Coruña \\ José Miguel Túñez-López \\ Universidade de Santiago de Compostela
}

PARA CITAR: Costa-Sánchez, C. y Túñez-López, M. (2018). Adprosumidores, medios sociales, vídeo online y Comunicación Corporativa. Tendencias inmediatas. En Túñez-López, M., Costa-Sánchez, C. y Valdiviezo, C. (Eds.), (2018). Comunicación Organizacional en entornos online. Gestión, actores y recursos. Cuadernos Artesanos de Comunicación, $\mathrm{n}^{\circ} 149$ (pp. 13-28). La Laguna (Tenerife): Latina.

\section{Resumen}

Todo está cambiando para la Comunicación Corporativa. Los públicos son influencers y los canales han mutado de unidireccionales a bidireccionales o multidireccionales y participativos. Los contenidos, híbridos, se mueven entre la promoción del afecto y la búsqueda de la credibilidad y la confianza. Si algo permanece ajeno a esta espiral de cambios en la Comunicación Corporativa es su objetivo último: la referencialidad. Las organizaciones pretenden la lealtad de los stakeholders, su apostolado y buscan relaciones positivas en una posición de influencia o de interinfluencia mutua. Este capítulo aborda tres de los nuevos cimientos de la Comunicación Corporativa del siglo XXI: adprosumers, social media y vídeo online.

Palabras clave: comunicación corporativa, social media, redes sociales, consumidores, vídeo online. 
En una época de cambios como la actual, la comunicación corporativa debe asumir los retos derivados del nuevo escenario digital en el que también se encuentran las organizaciones. Tal y como ya hemos sugerido (Túñez 2016), deberíamos pensar en una revolución en marcha, en un cambio radical e imparable que nos sitúa en un nuevo modo de entender y de hacer las cosas en un mundo cada vez más híbrido entre lo offline y lo online.

Las nuevas dinámicas han generado nuevos tiempos, nuevos actores, nuevas necesidades y nuevas formas (fórmulas) hacia un objetivo que se intensifica: mantener las relaciones con los públicos, mejorarlas, sí, pero más allá de ello, crear comunidad conjunta, organizaciones y públicos como parte de un todo.

La mayoría de los estudios y análisis sobre el sector profesional tanto en Europa como en el ámbito latinoamericano (Zerfass et al., 2017; Latinoamerica, 2017) destacan la incertidumbre de los propios profesionales ante los cambios del entorno digital y su planteamiento de nuevas inicitivas de reciclaje y formación que atiendan al nuevo contexto de trabajo. La estrategia y el entorno online se configuran como los dos nuevos retos que tienen por delante los profesionales.

El presente capítulo reflexiona sobre tres de los principales desafíos de presente y futuro a corto plazo del entorno online, en concreto:

- los nuevos públicos (que hemos denominado adprosumers),

- las nuevas tendencias en redes y plataformas participativas,

- y los nuevos contenidos (vídeo online).

\section{Adprosumidores o la influencia de los públicos}

El modo de relacionarnos socialmente se ha transformado de tal modo en los últimos años que hemos derivado los escenarios de nuestra actividad de comunicación personal y social hacia soportes que hibridan lo online y lo offline. Internet ha abierto un universo infinito de posibilidades de intercomunicación, pero a la vez se ha convertido en una tela de araña en la que caemos atrapados con limitación de movimientos. 
Todo ello plantea una cadena de derivaciones, pues las dinámicas, los tiempos, las necesidades y las convenciones de la comunicación se han reformulado. Hemos pasado de interactuar de uno a uno, o de uno a varios o, como mucho, en pequeños grupos, a relacionarnos todos con todos. Han variado, también, los flujos del mensaje, evolucionando de un modo unidireccional (discursivo) a una circulación realmente interactiva y, en simultáneo en/entre varios soportes. De este modo, la narración se construye y se modifica desde varios actores, desde múltiples emisores y a través de más de un canal.

La comunicación, gracias a la Web 2.0, deja atrás la era de la información para incursionar en la era de la participación. Esta evolución genera un cambio en el comportamiento de las audiencias que, aprovechando los nuevos medios, de manera voluntaria se convierten en referencia de otros consumidores al hacer visible su nivel de satisfacción o insatisfacción con un determinado producto o servicio y en referente de muchos otros usuarios. Así, por ejemplo, en el ámbito turístico, solemos recurrir a plataformas en las que figuren las opiniones de otros viajeros sobre un determinado destino, un hotel o un restaurante antes de decidirnos por uno en concreto. Bien por medio de las redes sociales personales o en comunidades específicas e inclusive en las plataformas de comunicación de las empresas, los públicos están influyendo e interfiriendo de esta forma en los procesos de selección y de compra.

Las redes sociales, por lo tanto, han supuesto una revolución que ha modificado la forma en que se relacionan la oferta y la demanda en el mercado. Los usuarios han pasado a controlar cómo se genera, se organiza y se comparte la información, debido a elementos tales como el aumento del número de clientes más formados y exigentes; la saturación publicitaria como consecuencia de la abrumadora cantidad de mensajes comerciales; el nacimiento de nuevos líderes de opinión, como los bloggers (puesto que la generación de contenidos de difusión inmediata hacen que cualquiera pueda convertirse en prescriptor); la pérdida de credibilidad de los medios de comunicación tradicionales; y el nacimiento de comunidades en la red con las mismas preferencias u opiniones (Oviedo García et al., 2015). 
Por ello, se propone un nuevo término que alude al nuevo rol que juegan los públicos, de prosumidores (productores y consumidores de contenidos) pasamos a adprosumidores (AD-anuncio, PROprodutor y SUMER-consumidor) porque realizan simultáneamente funciones de comprador, de consumidor y de recomendador de productos.

Las redes se convierten así en una plataforma idónea para el intercambio, no siempre consciente, de información y "las empresas también aprovechan las posibilidades de estas plataformas de interacción y de creación múltiple para conocer el perfil de su consumidor" y, al mismo tiempo, otorgarle protagonismo en campañas en las que se sienta participe (Marta, Martínez y Sánchez, 2013: 43).

En el ámbito empresarial, las comunidades virtuales (o cualquier forma de agrupación de usuarios, consumidores o adprosumidores) adquieren un papel estratégico en la comunicación porque hacen posible que se establezcan relaciones estrechas entre las organizaciones y sus stakeholders basadas en el compromiso y en la relación interpersonal. La universalización de la posibilidad de ser emisores que puedan llegar a públicos antes anónimos y la capacidad de articular relaciones bidireccionales ha supuesto que los públicos dejen de ser receptores finales en el proceso de comunicación para convertirse en emisores: podemos decir y ser oídos y esto fractura el monopolio discursivo que hasta ahora tenían las organizaciones sobre si mismas o, lo que es lo mismo, sobre la narrativa en torno a sus actividades y sus productos/servicios. Antes, primero experimentábamos el producto y después comprábamos. Ahora, compramos y después experimentamos.

Se ha transformado notablemente el proceso. En el mundo offline el estímulo de acción, por ejemplo, comprar un producto, continua en la experimentación de ese producto antes de ejecutar el pago. En entornos online la cadena es diferente. El momento zero de la verdad (ZMOT, Zero Moment of Truth) está en la búsqueda web y el impulso continúa en ejecutar la acción de compra y después recibir y experimentar el producto. En este caso, la cadena aún tiene un paso más porque después del pago se estimula la evaluación del producto y de la experiencia como usuarios de la web. 
El cambio está en que este eslabón final de la relación online (UMOF, Ultimate Moment of Truth) se incorpora al proceso como un ZMOT porque es una de las primeras acciones de los nuevos usuarios/compradores que antes de ejecutar la acción de pago revisan la evaluación que han hecho del servicio o del producto otros usuarios y evalúan la confianza del sistema de obtención de esas evaluaciones.

Este nuevo modo de comportarse de los públicos incorpora la integridad de las organizaciones (Kotler, 2011) como componente central del modo de gestionar la comunicación con transparencia. La proactividad de los usuarios obliga a las organizaciones a orientar su forma de relacionarse online y offline generando credibilidad en sus servicios, sus productos y sus prácticas.

La proactividad de los usuarios conduce a las organizaciones a orientar su forma de relacionarse online y offline generando credibilidad en sus servicios, sus productos y sus prácticas. La identidad (lo que proyecta y el conjunto de símbolos y acciones que utiliza para hacerlo) ha de adecuarse o lo hace para generar una imagen (el modo en el que los usuarios perciben la identidad) que se ajuste a la realidad y que no genere expectativas que finalmente no se puedan cumplir. Es lo que podemos denominar el proceso de la triple i: integridad del binomio identidad-imagen.

\section{Medios sociales, espacios en comunidad}

La comunicación corporativa se halla inmersa en una situación de cambio socio-tecnológico desde hace más de una década debido a la irrupción de Internet y al éxito de los social media como nuevos canales de comunicación. Y más allá de eso: los perfiles de los públicos también cambian, así como los modos de información o de comunicación o la propia percepción de lo que deben ser las organizaciones y cómo deben comportarse.

Los nuevos medios son los causantes de que las organizaciones hayan perdido el monopolio discursivo sobre sí mismas, sus productos o sus servicios. 
"Los medios de comunicación emergentes han aparecido durante el siglo XXI, lo que brinda enormes oportunidades para que las empresas puedan comunicarse mejor con el público. La vanguardia de estos nuevos medios es bien conocida como redes sociales, parte de la revolución de la Web 2.0" (Gómez y Soto, 2011: 161).

El cambio ha afectado, al menos, a la filosofía y la política de comunicación dominante, al rol de los usuarios que ya hemos comentado y al tipo de relación online que se establece entre organización y públicos.

El concepto de "social media" incluye plataformas, herramientas y canales online de muy diverso tipo. El tiempo hace que algunos caigan en desuso, que surjan otros que los releven y muchos que se mantengan. Son los cambios evolutivos del propio ecosistema digital.

Como decíamos, las dinámicas son cambiantes y el éxito social de una determinada herramienta está rodeado de incertidumbre. Olvido García et al. (2015) proponen una tipología dentro de dichos medios sociales que pasa por abarcar: blogs, redes sociales, social news, social measuring, microblogging, social bookmarking, social $Q \& A$, videosharing, photo sharing, social search, profesional networks, niche communities, redes basadas en la geolocalización, comment communities, regional social media sites, podcasting communities, blog networks, blogging communities, presentation-sharing sites, content-driven communities, product-based communities, recommendation sites y social media sites that defy definition.

El adjetivo "social" está detrás de todas las tipologías y denominaciones enumeradas. Ello significa que abarcan a una red de usuarios, que suelen implicar la premisa de compartir contenidos y la activación de dinámicas colaborativas de uno u otro modo.

\section{Contenido atractivo y vídeo online}

La Web 2.0 no solo ha traído consigo un paradigma participativo y social, sino también multimedia (Lloret y Canet, 2008). De ahí se deriva el éxito del consumo de vídeo online, que continuará creciendo hasta 
suponer el 80\% del tráfico global en Internet en 2019 según el pronóstico de Cisco.

El éxito de nuevas plataformas como el smartphone o la tablet han favorecido un consumo audiovisual, compartible y, en determinados casos, viral (Martín Núñez, 2014). El vídeo multiplica la participación, el afecto hacia la marca y la (re)difusión del mensaje (Moreno, 2014).

Ver vídeos, navegar por Internet y consultar las redes sociales son las actividades más realizadas desde el móvil. Se prevé que entre 2016 y 2022 el uso de vídeo desde el móvil aumente un 50\%. Además, el vídeo refuerza su posicionamiento como contenido preferido para los usuarios del móvil. Un 78\% de los españoles asegura ver vídeos desde el dispositivo a diario, seguido por el uso de la mensajería instantánea con WhatsApp a la cabeza (Ditrendia, 2017).

Sin caer en una perspectiva excesivamente técnica ni en una fe en la tecnología que carezca de sentido crítico, lo cierto es que el nuevo código de la Red y de los medios de comunicación es audiovisual (Costa-Sánchez, 2014).

La Comunicación Corporativa se está adaptando al contexto a través de sus canales de comunicación habituales y aquellos que han incorporado: la web corporativa, la intranet, la sala de comunicación online o el empleo de las redes sociales y social media. Las campañas publicitarias de las grandes marcas se vuelven transmedia y combinan medios masivos y segmentados (Del Pino y Fajardo, 2010), fundamentalmente televisión e Internet, donde el spot televisivo funciona como teaser para luego acceder a más contenidos por medio de la web y del nuevo canal de consumo audiovisual por excelencia, Youtube.

El empleo de la combinación de vídeo y web resulta de utilidad para la Comunicación Corporativa, en sus vertientes externa e interna.

Según el European Communication Monitor 2017 (Zerfass et al., 2018), un 94,4\% de los profesionales europeos de la Comunicación Corporativa está de acuerdo en que los elementos visuales serán más 
importantes para una comunicación estratégica en el futuro. Siete de cada diez organizaciones han detectado una demanda creciente de comunicación visual por sus stakeholders y un porcentaje superior ya ha expandido sus actividades en este campo. Un 89,5\% de los profesionales encuestados aseguran que la comunicación visual les requiere competencias específicas.

En cuanto a los contenidos visuales/audiovisuales que más han crecido en importancia (en comparación con 3 años antes), vídeos online e infográficos son reconocidos como más importantes por la mayoría de los profesionales preguntados.

Gráfico 1. Valores medios del nivel de experiencia reconocido en competencias de creación visual

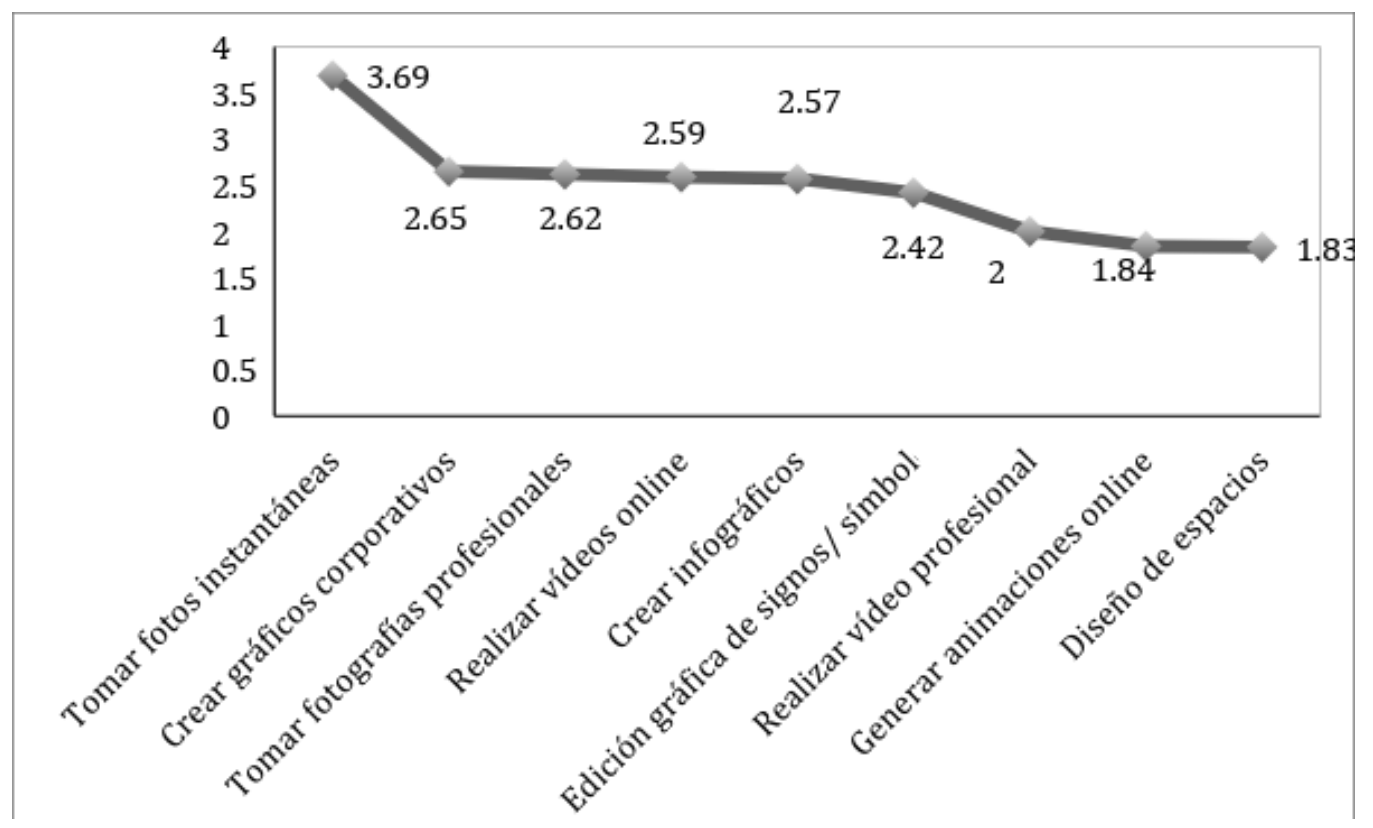

Fuente: European Communication Monitor 2017. Elaboración propia.

En referencia a sus competencias visuales [audiovisuales], la competencia más desarrollada es la de tomar fotos instantáneas, mientras que la elaboración de gráficos para la organización o la toma de fotografías profesionales se ubican en unos niveles de experiencia reconocidos intermedios o bajos. El vídeo profesional o las animaciones figuran en los niveles de competencias reconocidas más bajos. 
El panorama descrito ayuda a fundamentar dos cuestiones:

- En primer lugar, la importancia de la comunicación audiovisual para la comunicación corporativa dado el contexto actual y las tendencias de futuro.

- En segundo lugar, las necesidades que ya detectan los departamentos de comunicación de las organizaciones europeas (tanto empresariales, como institucionales o del Tercer Sector) de profesionales con competencias en la generación de contenido audiovisual fundamentalmente para los nuevos entornos online.

\section{Decálogo para una gestión eficaz de la comunicación}

Este nuevo modo de comunicarse socialmente obliga a las organizaciones a redefinir su comportamiento comunicacional en varios aspectos y a buscar nuevos aliados en sus desarrollos estratégicos, además de los tradicionales campos afines de las Ciencias Sociales. El nuevo enfoque de la Comunicación Organizacional podría empezar a delimitarse con el decálogo de recomendaciones que, a nuestro modo de ver, define los puntos de partida para encarar la gestión de la Comunicación en las organizaciones del siglo XXI:

1. Adaptarse a los nuevos modelos de comunicación. Las organizaciones de todo tipo deben adaptarse al cambio, porque los individuos han conquistado la capacidad de intercambiar sus opiniones referentes a los productos, servicios, prácticas, mensajes y actitudes de las organizaciones con las que se relacionan. Y han ganado, además, la posibilidad de responder a los mensajes que estas envían a los públicos por canales de retorno, es decir, los usados por las propias organizaciones, o a través de soportes que llegan a los públicos y excluyen a las organizaciones.

2. Ser transparentes. Adecuar su conducta y sus prácticas a sus mensajes, unificar lo que se dice y lo que se hace y estar en condiciones de satisfacer las expectativas que se generen porque la integridad (Kotler, 2011) ha pasado a ser un nuevo componente del modo de gestionar comunicación y de la forma 
de hacer las cosas para construir o mantener una reputación favorable.

3. Comprometerse. Ajustarse a las convenciones y lenguajes utilizados por todos y aprender a ser uno más en el grupo. Es decir, humanizarse, aproximarse y mimetizarse con la colectividad de la que forma parte como miembro de un grupo que interactúa. $\mathrm{Y}$ en entornos online, hacerlo asumiendo el compromiso 2.0 (Túñez y Sixto, 2011) de interacción bidireccional real.

4. Crear comunidades. Las organizaciones deben tener su propio público con canales de contacto directo para tomar la iniciativa de comunicar cuando lo necesite y poder hacerlo sin la dependencia de agentes o medios externos. Esto significa crear tribu o comunidad en la que la organización juega un papel predominante, pero dejando margen de actuación a sus miembros para que estos interactúen entre sí y acaben por ser los que co-generen contenidos y los que ayuden a que esa tribu o esa comunidad se mantenga activa y crezca.

5. Pasar del discurso al diálogo y a narrativas transmedia. La audiencia demanda relaciones informativas que se basen al menos en una actitud mediática discursiva y se oriente más a una actitud de diálogo que les permita dejar de ser receptores finales para ser actores activos en el proceso (Túñez, Martínez y Abejón, 2010). Las organizaciones se plantean un nuevo objetivo: el de proporcionar experiencias a unos usuarios (potenciales consumidores y prescriptores de la marca) que quieren tomar un rol más activo en los procesos comunicativos, gracias a las nuevas destrezas y oportunidades proporcionadas por la Web 2.0, que tienen nuevas dinámicas de consumo mediático y cuya atención se convierte en el bien más preciado (Costa-Sánchez, 2014b). Hoy es habitual que una historia discurra en simultáneo en redes, en webs, en aplicaciones y en la misma vida personal. Y los medios, como organizaciones que son, han de aprender que lo importante es pensar como el destinatario hasta mimetizarse con él, hasta ser como él, hasta ser él. Por eso los contenidos se van 
ajustando a las particularidades del soporte y se abandona la idea de un mismo formato replicado en diferentes plataformas.

6. Historias y contenidos líquidos. Atender a las nuevas formas de interrelación comunicativa de la sociedad, con narraciones en paralelo en varios soportes que obligan a realizar planificaciones transmedia. Interesan los mensajes que se transmiten como historias por eso se ha de tender al storytelling y a elaborar contenidos adaptables a estos nuevos flujos, ajustando la idea de Zygmunt Bauman (2003), se ha dado en denominar contenidos líquidos: una aportación fácilmente ajustable a las condiciones, a las exigencias, a los lenguajes y a las necesidades de cada soporte a medida que se va produciendo el trasvase en las narraciones transmediáticas. Obviarlo sería planificar pensando en estructuras comunicativas del pasado. (Túñez, 2016). Estas estructuras líquidas van más allá de la metáfora de la adaptación al soporte. Contenidos líquidos quiere decir que son fácilmente adaptables, pero también que no son propuestas únicamente elaboradas por las organizaciones, sino que se asume que han de acabar de tomar forma a través de las aportaciones de los usuarios a los que se debe permitir ser coautores (y en parte protagonistas) del relato.

7. Generar co-creacion y viralidad. Para tener presencia en un entorno digital se requiere que las organizaciones creen contenidos multimedia específicos para cada plataforma, los mismos que deben ser lo suficientemente atractivos e impactantes para conseguir que los usuarios los compartan y referencien generando un efecto viral en la red. Pero ha de hacerse teniendo en cuenta que los públicos no solo son reemisores: su aspiración es generar contenidos, individualmente o aliados a las organizaciones.

8. Incorporar la inteligencia artificial y la red semántica o $\mathbf{3 . 0}$ como referente de actuaciones e instrumento para una hipersegmentación de públicos que permita un conocimiento fondo de sus hábitos y de sus necesidades. 
9. Planificar no solo actuaciones sino productos. En la actualidad el ejemplo estaría en las aplicaciones (datos de descarga diaria) como complemento a los entornos y a las herramientas de interacción y como aliciente para convertir públicos potenciales en usuarios o usuarios esporádicos en seguidores fidelizados.

10. Adaptarse a nuevos formatos. Incluir las aplicaciones móviles y de geolocalización porque la transformación de los terminales en movilidad (también de los televisores, tendentes a la hibridación) significan conexión las 24 horas que se refuerzan por la geolocalización y el 3.0. Pero es necesario, adaptar las estrategias comunicacionales, ya que "el Smartphone es un dispositivo de uso personal, que proyecta identidad, lo natural sería que permitiesen un mayor acomodo a los gustos y preferencias informativas y de uso del lector" (Costa-Sánchez, 2014), lo que permitiría desarrollar una mejor comunicación con el usuario gracias a elevada tasa de penetración de los teléfonos inteligentes.

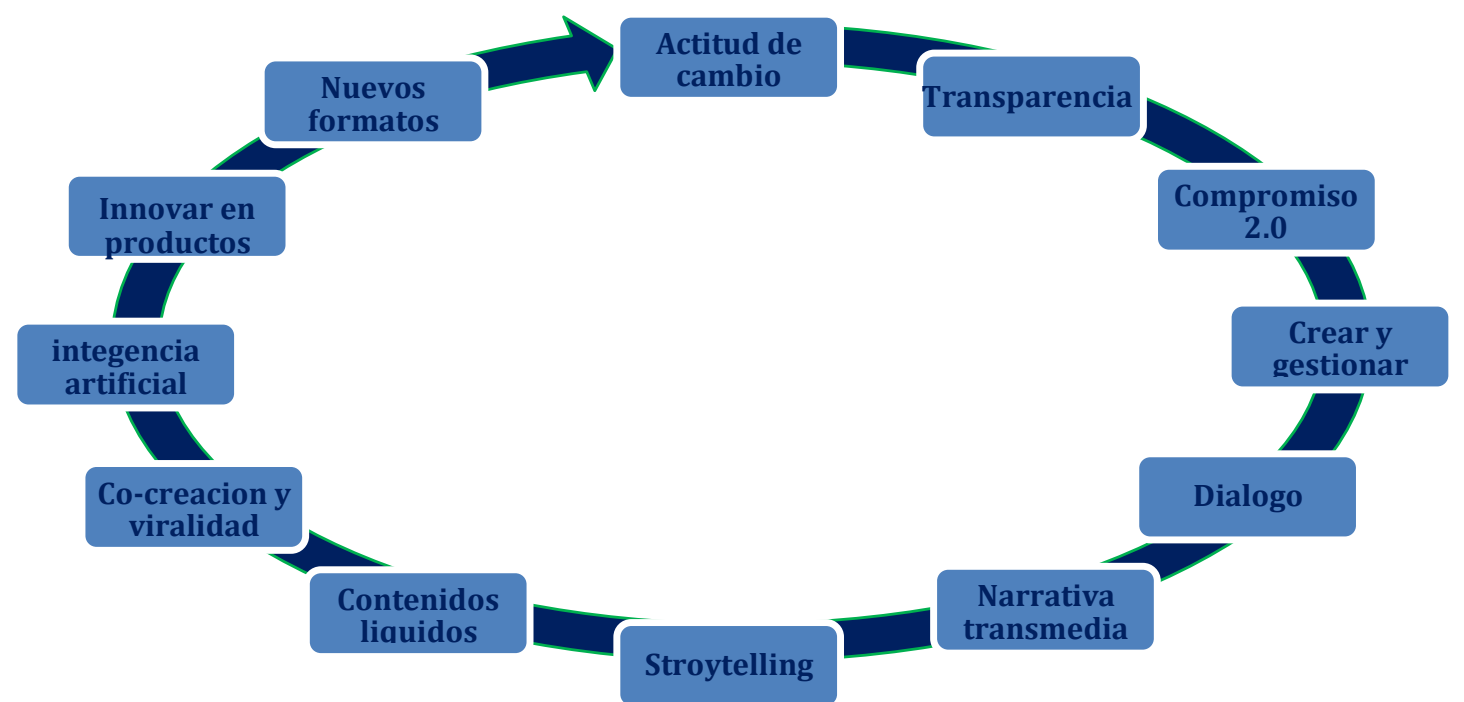

Figura 1. Reglas para una gestión eficaz de la comunicación en entornos online. Elaboración propia.

En la Comunicación Organizacional el área de acción abarca desde el clima laboral y su impacto en la productividad hasta la cooperación con otras disciplinas, como la inteligencia artificial o la neurología, que ayuden a entender mejor cómo nos relacionamos y que sirvan para ajustar los procesos comunicativos a las necesidades de la organización y a las expectativas de los individuos. 
Cada vez más afloran las interrelaciones entre áreas y el interés por abordar la gestión de la comunicación como el modo adecuado para lograr un correcto manejo de las relaciones con los públicos (usuarios y clientes incluidos) y los stakeholders internos y externos.

El objetivo ha de ser lograr el equilibrio para que esos procesos comunicativos y las relaciones entre la organización y sus públicos se produzcan no solo a través de un modelo simétrico bidireccional (Grunig y Hunt, 1984) sino en lo que, proyectando la calificación aportada por Grunig, podríamos etiquetar como el modelo de simetría interactiva. Es decir, relaciones que se desarrollan entre actores con conductas independientes pero situados en planos de igualdad y de influencia mutua, en la que ambos tienen capacidad de emisión masiva, de iniciativa en el manejo de sus relaciones, y de respuesta individual o grupal a sus comunicaciones. Como señalan Túnez, Costa y Míguez (2018), "lo importante ya no es comunicar pensando en el público, sino siendo público".

\section{Referencias}

Argenti, P., Howell, R.A. y Beck, K.A. (2005). "The strategic communication imperative", MIT Sloan Management Review, 46 (3), 83-89.

Atzori, L., Iera, A. y Morabito, G. (2010). “The internet of things: A survey", Computer networks, 54(15), 2787-2805.

Ayuso, S., Rodríguez, M.Á. y Ricart, J.E. (2006). "Using stakeholder dialogue as a source for new ideas: a dynamic capability underlying sustainable innovation", Corporate Governance, 6, 4, 475-490.

Bauman, Z. (2003). Modernidad líquida, Buenos Aires, Fondo de Cultura Económica.

Caro, J., Luque, A. y Zayas, B. (2014). “Aplicaciones tecnológicas para la promoción de los recursos turísticos culturales”. En XVI Congreso Nacional de Tecnologías de la Información Geográfica, Alicante. Recuperado el 12 de julio de 2015, de http://goo.gl/2Svq61.. 
Castillo, A. y Almansa, A. (2004). "La estructura y el funcionamiento de los gabinetes de comunicación en España", Anagramas, 2 (4), 47-62.

Celaya, J. (2009). La empresa, en la web 2.0, Barcelona, Gestión 2000. Coombs, W.T. (2000). "Crisis management: advantages of a relational perspective”, en J.A. Ledingham, y S.D. Bruning S.D., Public relations as relationship in management: A relational approach to the study and practice of public relations, Mahwah Lawrence Erlbaum.

Costa-Sánchez, C. (2014). “Las singularidades del medio móvil: integración multimedia, personalización, geolocalización y participación. Estudio de su presencia en las apps de la prensa española”. Palabra Clave, 17 (3), 672-694. DOI: 10.5294/pacla. 2014.17.3.5

Costa-Sánchez, C. (2014) 'Transmedia Storytelling, an ally of Corporate Communication: \#Dropped by Heineken case study", Communication y Society, Vol. 27, n. 3, 127-150.

Costa, J. (2014). El DirCom hoy: Dirección y Gestión de la Comunicación en la nueva economía, Costa Punto Com

Freeman, R.E. (1984) Strategic management: a stakeholder approach, Maryland, Pitman.

Grunig, J.E. (2000) "Collectivism, collaboration, and societal corporatism as core professional values in public relations", Journal of Public Relations Research, 12 (1), 23-48.

Grunig, J.E. (1989). "Publics, audiencies and marjet segments: segmentation principles for campaigns", en Salmon CT, Information campaigns: balancing social values and social change, California, Sage, 199-228.

Grunig, J.E. y Hunt, T. (2003) Dirección de relaciones públicas, Barcelona, Gestión 2000. Traducción de Managing Public Relations, Orlando-Florida, Harcourt Brace Jovanovich, 1984.

Harris, T.L. (2002). Value-added public relations: the secret weapon of integrated marketing, Chicago, NTC Business Books, 1998. Harrison, S. Relaciones públicas, una introducción, Madrid, Thompson. Kotler, P. (2011) Marketing 3.0, Madrid, Lid editorial.

Lauzen, M. y Dozier, D. (1992). "Missing link: the public relations manager role as mediator of organizational environments and 
power consequences for the function", Journal of Public Relations

Research, 4 (4), 205-220.

Lesly, P. (1969) Manual de relaciones públicas. Barcelona, Martínez Roca. López Sánchez, J.A., Santos Vijande, M.L. y Trespalacios Gutiérrez,

J.A. (2010). "Perspectivas de análisis en la creación de valor para el cliente en las relaciones comprador-vendedor: un estudio empírico", Tribuna de Economia No 854, Mayo-Junio.

Martínez-Solana, M.Y. (2004). La comunicación institucional: análisis de sus problemas y soluciones. Madrid, Fragua.

Míguez, M.I. (2010) Los públicos en las relaciones públicas. Barcelona, UOC.

Rosales, P. (2010). Estrategia digital. Cómo usar las nuevas tecnologías mejor que la competencia, Barcelona, Ediciones Deusto.

Soto-Velez, I. (2009). "Teorías y trasfondo de las relaciones públicas internacionales", Palabra Clave, (12), 1.

Tilson, D.J y Saura, P. (2003). "Public relations and the new golden age of Spain: a confluence of democracy, economic development and the media", Public Relations Review, 29 (2), 125 143.

Túñez-López, M. y Costa-Sánchez, C. (2016) (Eds.). Interaçao

organizacional na sociedade em rede. Os novos caminhos da comunicaçao na gestao das relaçoes com os públicos.

Cuadernos Artesanos de Comunicación, no 102. La Laguna

(Tenerife): Latina.

Túñez-López, M. (2012). La gestión de la comunicación en las organizaciones. Sevilla/Zamora, Comunicación Social.

Túñez-López, M. (2015) "Modelo de simetría interactiva en Comunicación Organizacional", Revista Mediterránea de Comunicación, 6(2), 5-7. Disponible en http://mediterraneacomunicacion.org/. DOI:

10.14198/medcom2015.6.2.14

Túñez-López, M. y Altamirano, V. (2016). “A simetría interativa na

Comunicaçao Organizacional”, en M. Túñez López y C. CostaSánchez, C. (Eds.). Interaçao organizacional na sociedade em rede. Os novos caminhos da comunicaçao na gestao das relaçoes com os públicos. Cuadernos Artesanos de Comunicación, no 102, La Laguna (Tenerife), Latina, 13-20. 
Túñez-López, M. y Sixto-Garcia, J. (2011). "Redes sociales, política y Compromiso 2.0: La comunicación de los diputados españoles en Facebook", Revista Latina de comunicación social, (66), 9.

Túñez-López, M., Martínez-Solana, M.Y. y Abejón Mendoza, P. (2010). "Nuevos entornos, nuevas demandas, nuevos periodistas", Estudios sobre el Mensaje Periodístico, (16), 85.

Túñez-López, M. (2016). "Perspectivas de la gestión de la comunicación en el siglo XXI", en C.L. Andrade Scroferneker y L. Ramírez de Amorín, (Re) Leituras Contemporaneas sobre comunicaçao organicacional e relaçoes públicas. Porto Alegre (Brasil), Edipurs, Ponticifia Universidade Católica do Río Grande do Sul.

Túñez-López, M.Y, Costa-Sánchez, C y Míguez González, M.I. (2018). Avances y retos de la gestión de la comunicación en el siglo XXI. Procesos, necesidades y carencias en el ámbito institucional Estudios del Mensaje Periodistico (en publicación).

Weil, P. (1990). La Comunicación Global. Comunicación Institucional y de Gestión, Barcelona, Paidós, 1990. 


\title{
Gestión de stakeholders: un enfoque comunicacional
}

\author{
Valerie Báez \\ Corte Nacional de Justicia del Ecuador \\ Diego Apolo \\ U. Nacional Educación Ecuador/U. San Francisco de Quito \\ Gabriela Pasquel \\ Municipio del Distrito Metropolitano de Quito \\ Lizeth Pauker \\ Yasuní Medios
}

PARA CITAR: Báez, V et al (2018). Gestión de stakeholders: un enfoque comunicacional. En Túñez-López, M., Costa-Sánchez, C. y Valdiviezo, C. (Eds.), (2018). Comunicación Organizacional en entornos online. Gestión, actores y recursos. Cuadernos Artesanos de Comunicación, no 149 (pp. 29-52). La Laguna (Tenerife): Latina.

\section{Resumen}

Este capítulo profundiza en las bases teóricas y metodológicas para la gestión de stakeholders con un enfoque comunicacional. Se abordan diferentes perspectivas sobre las definiciones, clasificación, tipología, características e importancia de estos para la consecución de los objetivos institucionales y su relevancia como eje transversal para la construcción de estrategias que aporten valor a la imagen y reputación corporativa. Además, analiza el rol protagónico que desempeñan los grupos de interés en la gestión institucional.

Palabras clave: stakeholders, comunicación corporativa, toma de decisiones. 
Las actividades que toda institución desempeña han llegado a impactar en los diversos ámbitos del entorno en el cual se desarrolla; en tal sentido, resulta esencial considerar a los stakeholders como actores relevantes a la hora de construir estrategias. De este modo, al tomar en cuenta los impactos políticos, económicos, sociales y ambientales que afectan a la misma. Por ello, es fundamental primero conocer a sus grupos de interés para precisar y satisfacer con mayor exactitud sus expectativas, pero sobre todo sus necesidades.

Además, de determinar la manera en la que los mismos influyen, tanto dentro como fuera del entorno y por ello cabe su vínculo hacia la comunicación corporativa entendida como:

"La gestión de identidad, imagen y reputación que a través de la investigación permite identificar valores agregados, atributos, diferenciadores y ventajas competitivas; que mediante el direccionamiento estratégico de las herramientas comunicacionales contribuyen a la notoriedad y a la construcción de vínculos hacia los stakeholders, aportando al logro de los objetivos planteados" (Báez et al., 2017: 527).

Debido a la importancia de lo expuesto, es imprescindible recurrir a la definición de stakeholders propuesta por Freeman (1984) quien menciona que puede ser "cualquier individuo o grupo que puede afectar o ser afectado por el logro de los objetivos de una organización" (Freeman et al., 1984 citado en Rivera y Malaver, 2011: 22). Aunque resulta esencial comprender que esta aproximación abarca mucho más, pues también existen partes que actúan directa o indirectamente, al intervenir en el transcurso de las actividades de una organización, por ejemplo: organismos gubernamentales, comunidades, futuros empleados, potenciales consumidores o familias, sin dejar de mencionar a la competencia.

Para las empresas o instituciones, son todos los grupos de interés a los que buscan llegar a través de un mensaje, así existiese o no una relación directa, un claro ejemplo pueden ser los posibles clientes potenciales. 
Es importante reconocer que todas las organizaciones, tienen sus respectivos grupos de interés, y por tanto deben poseer conocimiento sobre cada una de sus necesidades; así como también la opinión que tienen estos sobre la misma. En tal virtud para establecer una relación de confianza entre las partes interesadas. En primer lugar, es primordial tener claro quiénes son los grupos de interés y de qué manera se va a actuar frente a ellos. Es así como no existe un listado predeterminado para seleccionar y priorizar a los stakeholders; todo dependerá de la situación, pero sobre todo de cada institución o empresa.

Para Lazzari y Moulia "es importante analizar la relación con los stakeholders como un proceso de mejora continua y en constante cambio. Las exigencias de cada grupo cambian con el tiempo, así como también cambia su importancia estratégica" (2015: 39). Por tanto, "se requiere de la gestión de comunicación para construir estrategias que pongan en diálogo la difusión de mensajes y la construcción de vínculos a largo plazo con los stakeholders" (Apolo et al., 2017: 19); sobre todo al considerar que la entidad debe comprometerse con los mismos, llevando a cabo acciones estratégicas comunicacionales que garanticen el entendimiento mutuo.

En diálogo con los anterior, Lafuente y Luciano aseveran:

"Debido a la complejidad que presentan las relaciones con los grupos de interés, las empresas y sus gestores pueden necesitar de herramientas flexibles que los auxilien en la toma de decisiones y los ayuden a mejorar la gestión y el diálogo con los stakeholders" (2011: 80).

Así pues, al ser el diálogo una de las herramientas más eficaces para procurar la satisfacción mutua; es importante conocer que, a nivel comunicacional, el término stakeholders hace referencia a todos los actores que se encuentran dentro del escenario organizacional (personas, grupos, instituciones, etc.), por lo que no considera únicamente a aquellos con los que se mantiene relaciones vigentes. Es decir, al hablar de stakebolders se refiere a los diferentes actores, con los que la institución o empresa debe interactuar de manera particular, a través de mensajes que se adecuen a sus necesidades 
comunicacionales, tomando en consideración las herramientas y canales con los que la organización cuenta. Así lo afirman Pasquel et al::

"El conocer cuáles son los factores que influyen sobre la percepción que tienen los stakeholders sobre la institución, permitiría a los altos mandos gestionar los recursos comunicacionales de una manera eficiente y eficaz, enfocando la construcción de sus objetivos, estrategias, actividades y acciones hacia el fortalecimiento de su imagen" (2015: 2).

En tal virtud, es fundamental que toda organización considere realizar su planificación y diseño de estrategias, con base en la identificación, diferenciación y desarrollo de acciones específicas para cada stakeholder, con el fin de alcanzar mediante esta gestión un trabajo integral, eficiente y eficaz que fortalezca sus activos intangibles.

A continuación, se presenta una tabla que demuestra la manera en la que están cambiando las diferentes formas de participación de los stakeholders, con respecto a los temas a tratar y cómo hacerlo:

\begin{tabular}{|c|c|c|c|}
\hline \multicolumn{4}{|c|}{ ¿Quiénes son sus stakeholders? } \\
\hline $\begin{array}{c}\text { De las interacciones } \\
\text { empresariales } \\
\text { tradicionales: }\end{array}$ & $\begin{array}{l}\text { Empleados, clientes, } \\
\text { proveedores, } \\
\text { inversores y } \\
\text { reguladores. }\end{array}$ & $\begin{array}{l}\text { Hacia grupos más } \\
\text { amplios: }\end{array}$ & $\begin{array}{c}\text { Comunidades locales, } \\
\text { trabajadores de la cadena de } \\
\text { compras, familiares de los } \\
\text { empleados, organizaciones de la } \\
\text { sociedad civil, medio ambiente... }\end{array}$ \\
\hline \multicolumn{4}{|c|}{ ¿Qué temas debe tratar con ellos? } \\
\hline $\begin{array}{l}\text { De temas legales y } \\
\text { contractuales: }\end{array}$ & $\begin{array}{l}\text { Marketing, relaciones } \\
\text { industriales, elección } \\
\text { de ubicaciones para } \\
\text { plantas, planificación } \\
\text { del negocio y compras. }\end{array}$ & $\begin{array}{l}\text { Hacia temas } \\
\text { emergentes y nuevas } \\
\text { responsabilidades: }\end{array}$ & $\begin{array}{l}\text { Corrupción, exclusión social, } \\
\text { derechos humanos, riesgos para la } \\
\text { salud, desarrollo económico, } \\
\text { consiciones laborales en la cadena } \\
\text { de compras, impacto ambiental... }\end{array}$ \\
\hline \multicolumn{4}{|l|}{ ¿Cómo hacerlo? } \\
\hline $\begin{array}{c}\text { De la comunicación } \\
\text { unilateral: }\end{array}$ & $\begin{array}{c}\text { Investigación de } \\
\text { mercado, } \\
\text { comunicaciones } \\
\text { corporativas, publicidad } \\
\text { y difusión en medios. }\end{array}$ & $\begin{array}{l}\text { Hacia el diálogo y la } \\
\text { colaboración: }\end{array}$ & $\begin{array}{l}\text { Consultas, paneles de } \\
\text { asesoramiento, retroalimentación } \\
\text { online, foros y alianzas de } \\
\text { stakeholders múltiples, redes de } \\
\text { convocatoria. }\end{array}$ \\
\hline
\end{tabular}

Figura 1. Cambios en la naturaleza en las relaciones de los stakeholders. Elaboración propia, basado en Krick et al (2006: 29) 


\section{Teoría de los stakeholders}

A partir de lo mencionado y con el fin de esclarecer ciertas dudas e inquietudes, se toma en consideración la llamada teoría de los stakeholders, misma que fue desarrollada por Freeman (1984), en su obra Strategic Managment, donde se define a esta como una metodología de gestión estratégica que contribuye a la planificación responsable y ética de cualquier organización.

En la revisión del estado del arte sobre stakeholders realizada por Freeman et al., (2010) se puede identificar que, en el pasado, las pequeñas y medianas empresas se limitaban a relacionarse con sus proveedores y clientes en un modelo de gestión familiar, donde no se priorizaba al resto de personas con las que de alguna u otra manera se encontraban relacionados, ya sea directa o indirectamente.

Es así como con el auge de la tecnología y la comunicación, las empresas se vieron obligadas a cambiar, puesto que a medida en que fueron creciendo y fortaleciéndose, algunas de estas se percataron que el impacto de sus actividades trascendía su entorno cercano convirtiéndolas en estructuras cada vez más complejas. Por lo que, se crea la necesidad de relacionarse e interactuar con los diferentes grupos de interés, tomando en consideración que toda empresa o institución necesita de una red de stakeholders con el fin de conocer sus necesidades en relación con los productos, bienes o servicios que presta.

De acuerdo con González (2007: 208-209) son varias las razones, por las cuales esta teoría ha demostrado tener relevancia en los últimos años, entre estas se encuentran:

- Se enfoca en un nuevo paradigma empresarial, en donde se aprecia a la organización como un todo, donde no solamente se involucran sus propietarios y trabajadores; sino también todos los agentes que de alguna u otra manera se encuentran relacionados con la misma. 
- Comprende que las relaciones existentes entre las organizaciones y los distintos stakeholders, no solamente se fundamentan en bases jurídicas o sociales, sino también morales. En otras palabras, al existir expectativas recíprocas de comportamiento, es necesario procurar satisfacerlas más allá del nivel económico.

- Facilita la presencia de responsabilidad social en las empresas, a partir de la consideración del sentido ético y moral. Es por ello, que en la actualidad dicha teoría, es una de las más utilizadas a la hora de poner en práctica programas de esta índole.

- Es vital reconocer que al hablar de stakeholders se hace referencia a "grupos de personas naturales o jurídicas con las que se tiene vínculo" (Orozco y Ferré, 2011: 111). Además, el término stakeholder puede ser empleado para referirse a las partes interesadas, grupos de interés o públicos objetivos; lo esencial es tomar en consideración a todos y cada uno de los actores que entablan relaciones con las organizaciones.

En la actualidad las empresas no toman decisiones pensando únicamente en satisfacer sus propios intereses; sino, también tomando en consideración las necesidades de los stakeholders. De tal manera que se ha considerado a esta teoría como una nueva forma de gestión administrativa en la que se comparte la idea de una nueva perspectiva enfocada en los grupos de interés. La cual surge debido a la influencia que estos tienen en las decisiones tomadas a nivel empresarial, al convertirse en agentes interlocutores, antes que simples espectadores. Para Agüero, Carbonell y Martínez, "la teoría de los stakeholders incorpora dentro del proceso de toma de decisiones a ciertos grupos que anteriormente habían sido excluidos por considerarse ajenos a la actividad empresarial" (2006: 32).

En definitiva, esta teoría hace referencia a una concepción general de estrategia organizativa y ética, por lo que su idea central radica en comprender que el éxito de una determinada compañía depende del acierto con el que se manejen los vínculos existentes con los grupos de interés para esta. De tal manera, que no se lleguen a perjudicar los objetivos empresariales propuestos. Así pues, este se encuentra 
direccionado hacia la generación de información ética y la promulgación de las diversas actividades ejecutadas por la organización, más allá de un enfoque en la gestión de relaciones.

\section{Importancia de la gestión de los grupos de interés}

Al identificar y satisfacer adecuadamente las expectativas y necesidades de los grupos de interés, en cierta manera se garantiza el éxito empresarial; puesto que los stakeholders tienen la potestad de contribuir al crecimiento o fracaso de una organización. Así pues, toda buena o mala decisión tomada por la organización y que influya sobre los stakeholders puede provocar una serie de éxitos o fracasos, por lo que se determina que los stakeholders desempeñan un rol fundamental en cuanto a la toma de decisiones en la empresa.

Pensar que el análisis de los stakeholders se circunscribe solamente a la actividad empresarial, sería limitarlo en exceso. Por ello, de acuerdo con Freeman (1984) citado en Ángel, expresa:

"El principal objetivo del concepto de stakeholders como teoría es afirmar y mostrar que la gestión de un proyecto es responsabilidad no sólo de los financiadores y ejecutores, sino también de los demás individuos o grupos que tienen algún interés en las acciones y decisiones de dicho proyecto" (2010: 493).

Asimismo, al establecer y desarrollar relaciones más estrechas y directas con los grupos de interés, se contribuye a la creación de una plataforma de aprendizaje, innovación y mejora que no únicamente influye en los resultados económicos; sino también en los sociales y ambientales. Son varias las razones por las cuales se debe considerar de importancia la relación con los diferentes stakeholders, en primer lugar, porque influyen directamente en el éxito o fracaso de la organización y también por su implicación en la actividad diaria. En segundo lugar, otro aspecto de importancia es que "la gestión de stakeholders es el paradigma que más ha transformado el management. 
Su derecho a disponer de información ha traído consigo una era de transparencia en las empresas que convive con los riesgos a la revelación de determinada información" (Vaccaro, 2011: 1).
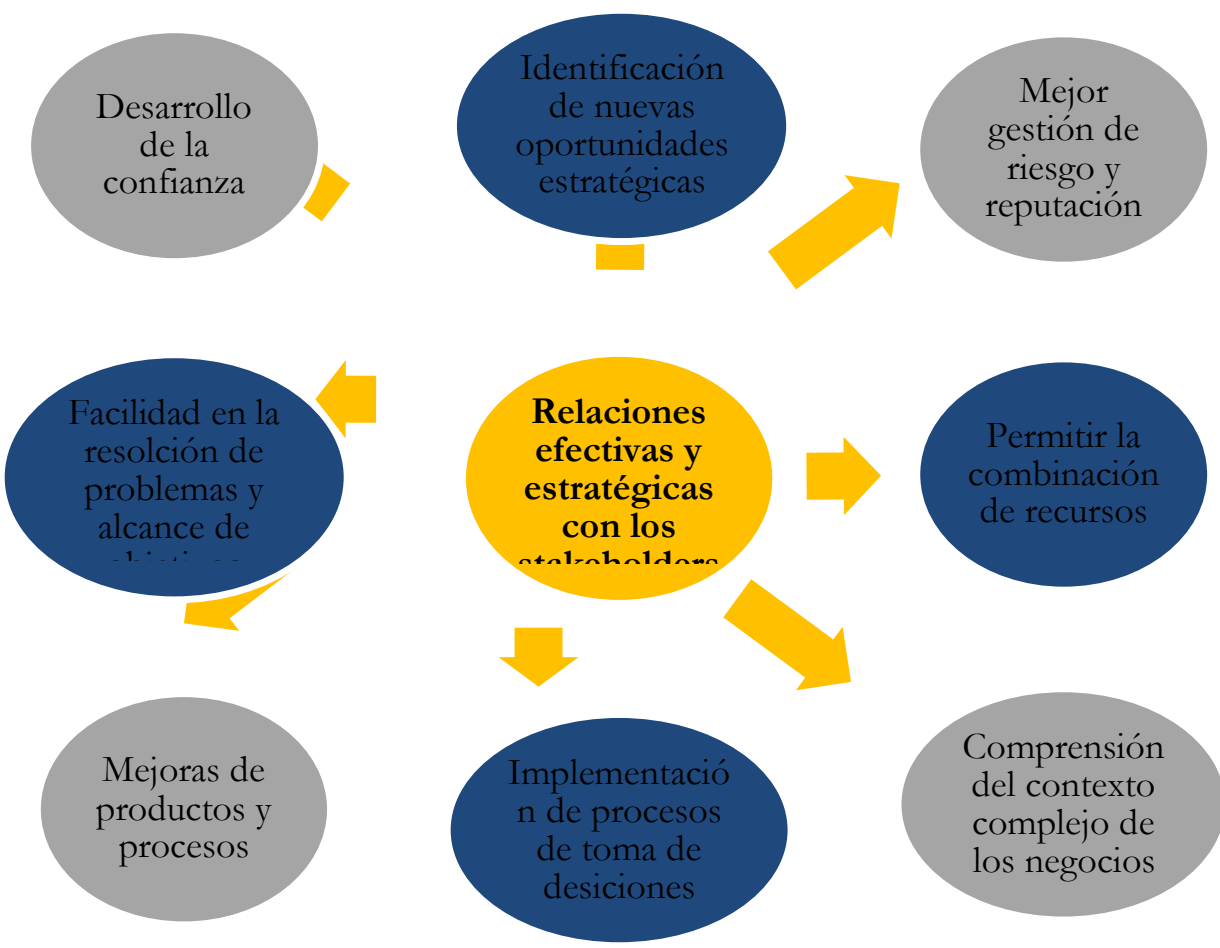

Figura 2. Relaciones efectivas y estratégicas con los stakeholders Elaboración propia, basado en Krick et al. (2006: 13).

\section{Modelo de gestión de stakeholders basado en la comunicación}

Toda organización tiene que establecer y desarrollar relaciones de confianza y cooperación mutua con sus grupos de interés, para así crear vínculos que garanticen la generación de un valor compartido.

De esta manera, la gestión de las relaciones que la organización establece con sus stakeholders contribuye a la formación del capital social, entendiendo como todo aquello que posibilita la cooperación entre dos partes, en este caso entre la organización y sus grupos de interés. Es por ello, que en los últimos años se ha considerado "la identificación de las expectativas y demandas de los stakeholders, así como la integración de los mismos en la estrategia de una organización" (Acuña, 2012: 5). 
A continuación, se presenta un modelo de gestión de stakeholders basado en la comunicación corporativa, mismo que permite dar realce a este eje transversal que en muy pocas ocasiones es reconocido como un factor estratégico a la hora de alcanzar el éxito institucional y empresarial. Es así, que la relevancia de este modelo se centra en identificar y analizar el rol protagónico que desempeñan los grupos de interés; además de dar respuesta a qué, cómo y cuándo comunicar.

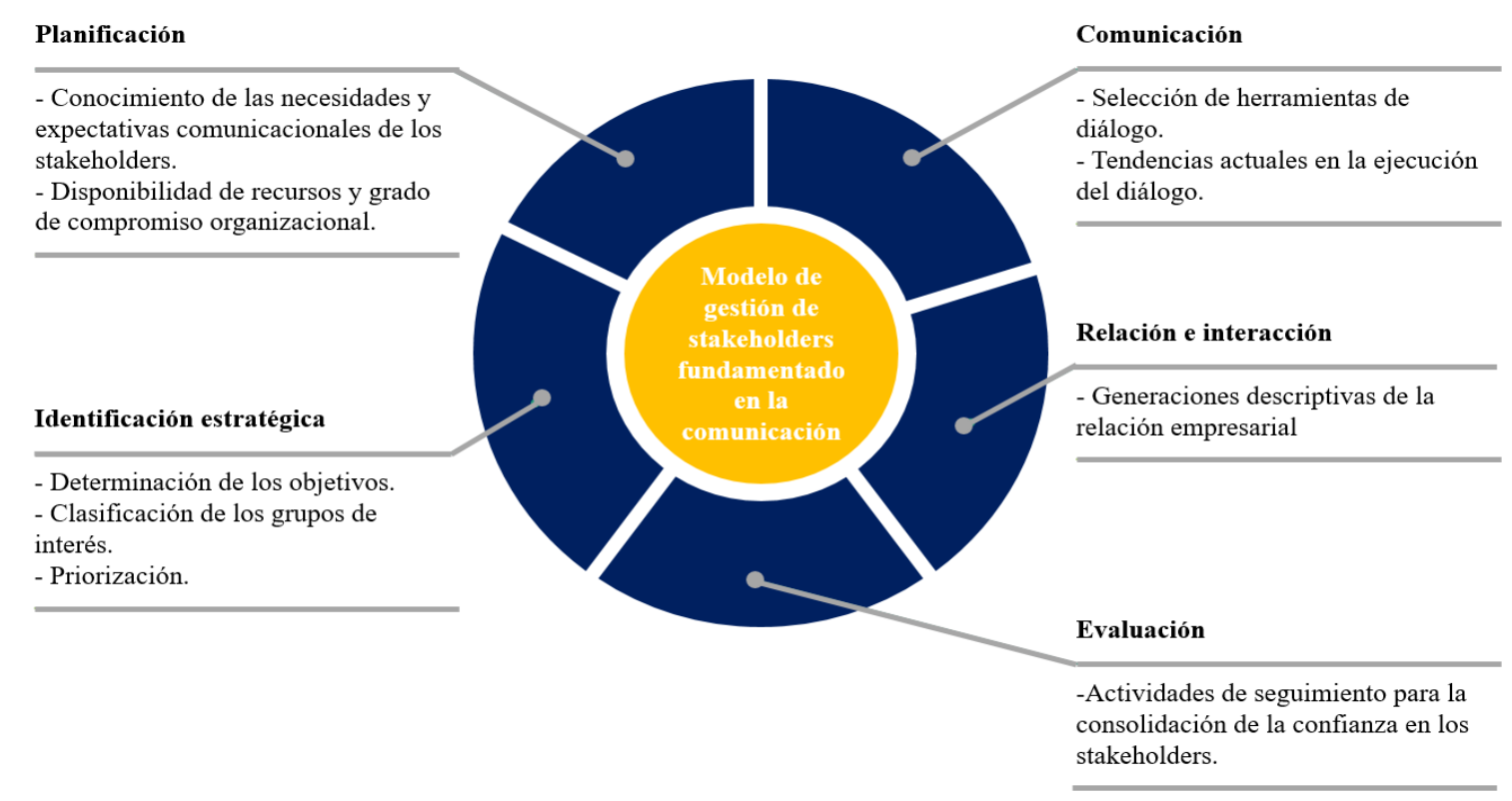

Figura 3. Modelo de gestión de stakebolders fundamentado en la comunicación. Elaboración propia

Los grupos de interés, con el pasar del tiempo han desarrollado relaciones más estrechas con las diversas organizaciones, generando igualdad de condiciones al momento de competir unas con otras; convirtiendo su gestión a nivel empresarial y comunicacional en la piedra angular que sostiene y mantiene a toda organización.

\subsection{Identificación estratégica}

Es el primer paso para el establecimiento del modelo, su importancia radica en determinar los objetivos estratégicos de la organización, para que con base en ello se identifiquen los grupos de interés y así proceder a priorizar los mismos. Para Granda y Trujillo "este es un elemento clave que, de no realizarse así, puede sentar las bases de un modelo 
incompleto o erróneo con el que la organización tome decisiones incorrectas" (2011: 72).

Sin embargo, es importante mencionar que no existe un modelo específico para categorizar a los stakeholders, pues los intereses de la organización van cambiando con el tiempo. Los grupos afectados y que afectan a la institución dependen de diversos factores, por lo que generalmente las nuevas estrategias de negocio y los cambios contextuales determinan distintos grupos de interés en diferentes momentos. Así para Lazzari y Moulia "la empresa se encuentra ante el desafío de estar al día con los cambios y tener un buen conocimiento de todos los actores con influencia en su esfera de actividad" (2015: 42). Así mismo, Granda y Trujillo aseveran que:

"es preciso tener en cuenta que este paso debe afrontarse como un proceso abierto, donde la naturaleza cambiante del entorno hará que aparezcan o desaparezcan agentes del ámbito que la organización debe contemplar" (2011: 73).

\subsubsection{Clasificación de los grupos de interés}

Para Clarkson (1995), es posible clasificar a los stakeholders en función de la homogeneidad presentada por los intereses en cuestión, es así que divide a los mismos en primarios y secundarios.

De esta manera, los primarios, hacen referencia al grupo de interesados indispensables para que cualquier tipo de organización continúe desarrollándose con sus labores operativas en la sociedad. Para Fernández y Bajo "al menos, bajo este rubro habría que incluir a los dueños y accionistas, a los empleados, a los clientes y a los proveedores" (2012: 138).

Con respecto a los grupos de interés secundarios, se refieren a aquellos que no se encuentran directamente involucrados con las actividades económicas ligadas a la organización. Aunque en caso de existir algún tipo de modificación, sí pueden llegar a ejercer su influencia. Retomando a Fernández y Bajo "aquí cabe un amplio abanico de potenciales grupos de interesados: competidores, comunidad en la que 
radica la empresa, medios de comunicación, miembros de la sociedad civil, organizaciones del tercer sector" (2012: 138).

De igual manera, es esencial indicar la existencia de los stakebolders globales, caracterizados por ser grupos u organizaciones conformadas por integrantes de diversos países que presentan intereses en común, con respecto a las actividades de las empresas y organizaciones económicas.

De acuerdo con Granda y Trujillo (2011: 73), existe una segunda forma de categorizar o diferenciar a los stakeholders, estos son:

- Por cercanía: son los grupos con los que la organización se relaciona de manera directa o, como su nombre lo indica, cercanos; es decir, son aquellos que resultan esenciales para la existencia de la empresa.

- Por influencia: hace referencia a aquellos grupos de interés que influyen o pueden llegar a hacerlo, tomando en consideración el desarrollo de las actividades empresariales.

- Por responsabilidad: son aquellos grupos de interés con quienes se mantienen obligaciones legales.

- Por dependencia: se refiere a aquellos grupos que dependen de las actividades ejecutadas por la organización.

Por su parte, Mitchell, Bradley y Donna (1997) proponen un modelo de identificación de los stakeholders fundamentado en los atributos como: poder, legitimidad y urgencia. Sin embargo, estas características solamente analizan a los stakeholders en un periodo de tiempo específico, sin tomar en consideración una visión a largo plazo; es por ello por lo que Clemens y Gallagher (2003) citados por Caballero añaden el atributo de durabilidad, pues argumentan que "aunque poder, legitimidad y urgencia son atributos importantes en la correcta identificación de los stakeholders, estos no dirigen adecuadamente los asuntos entre ellos y los directivos a largo plazo" (2007: 15). 


\subsubsection{Poder}

Hace referencia al grado en que los individuos son capaces de influir o persuadir en el seguimiento de ciertas líneas de conducta o en la toma de decisiones que no habrían tomado por su propia cuenta; con el fin de ser partícipes en las estrategias de la organización.

Por su parte, Mitchell et al, (1997) proponen los siguientes tipos de poder:

- Poder coercitivo: se basa en la fuerza física, violencia; puesto que conlleva el uso de armas o castigos físicos.

- Poder utilitario: permite el uso de recursos materiales o financieros. Es esencial, indicar que, en este caso, símbolos como el dinero permiten la adquisición de bienes y servicios.

- Poder normativo-social: se da a través de recursos simbólicos, donde no interviene el trato físico y mucho menos recompensas materiales; los mismos pueden ser normativos y sociales.

Para Lazzari y Moulia "cada tipo de poder debe ser sopesado según el grado de sensibilidad de la organización, que debe reflejar la importancia debida, la susceptibilidad o la vulnerabilidad en relación al recurso que afecta" (2015: 44).

\subsubsection{Legitimidad}

Se fundamenta en la percepción generalizada de que las acciones ejecutadas por un actor social son las más apropiadas dentro del sistema social constituido por normas, valores, creencias y definiciones. Se debe agregar que la legitimidad "es un bien común deseable, es un concepto amplio, no se trata de una mera percepción, y puede ser definida y negociada de modo diferente en los distintos niveles sociales de la organización" (Caballero, 2007: 16).

Del mismo modo, la legitimidad puede ser medida de acuerdo al grado de deseabilidad de las acciones del stakeholder, tanto para la organización, como para la sociedad. De esta manera, en caso de que los stakeholders cuenten con intereses legítimos en la organización, estos 
deben ser considerados como características propias de la misma, pues de todas maneras el stakeholder posee una capacidad de influencia moral y legal sobre el comportamiento de toda empresa.

\subsubsection{Urgencia}

Todo vínculo existente entre stakeholder y organización se encuentra marcado por el tiempo, convirtiéndose en un factor fundamental para la empresa. Es así que este atributo, representa el grado en el cual las demandas de las partes interesadas piden atención inmediata "esta solicitud se plantea en base a la existencia de dos condiciones: (1) la demanda es sensible al paso del tiempo en cuanto a su atención; (2) la demanda es importante o crítica para el stakeholder" (Lazzari y Moulia, 2015: 44).

\subsubsection{Durabilidad}

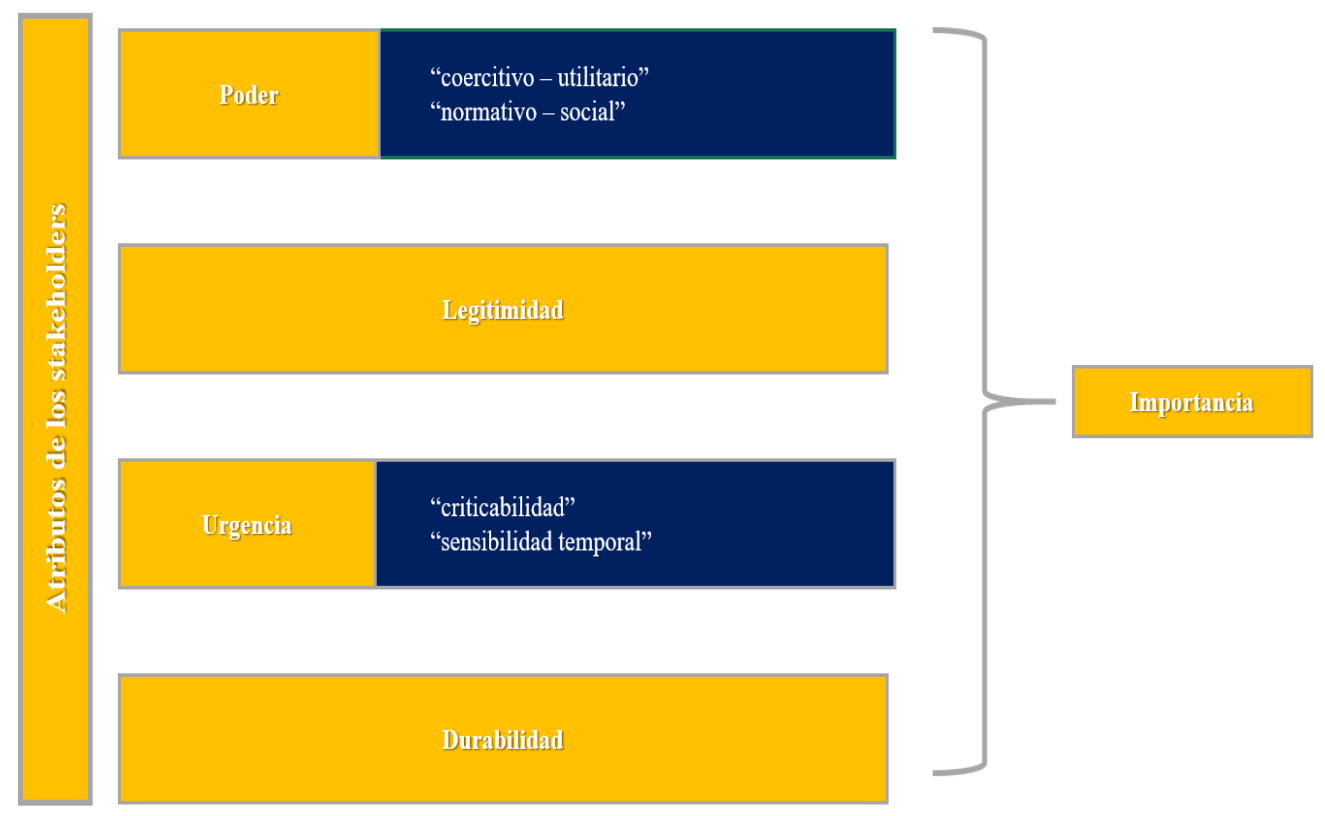

Figura 4. Atributos de los stakeholders. Elaboración propia, basado en Caballero (2007: 19).

Este atributo pretende comprender y prever la actitud de la mayor parte de los stakeholders en un futuro. Además, de provocar que ciertos grupos de interés tengan mayor influencia sobre otros. A través de la durabilidad, se pretende motivar y mantener a los stakebolders, considerando la experiencia con cada uno de ellos. Para Clemens y 
Gallgher (2003), citado por Caballero, la durabilidad es "aquel atributo que representa la continua habilidad de los stakeholders para exigir reclamaciones en la organización originadas por motivos legales, institucionales u de otro tipo" (2007: 17).

De esta manera, al enfocarse en tres de los cuatro atributos previamente mencionados (poder, legitimidad y urgencia); es posible, según Vaccaro (2011: 2), clasificar a los stakeholders de la siguiente manera:

- Stakeholders latentes: hace referencia a aquellos grupos de interés que cuentan solamente con un atributo; a pesar de que, con el tiempo, pueden adquirir otros y fortalecer su relación cada vez más. De esta manera pueden ser:

- Inactivos: solamente tienen poder; es decir que poseen la capacidad de imponerse sobre la entidad, mas no cuenta con legitimidad y mucho menos urgencia en el cumplimiento de sus expectativas y necesidades.

- Discrecionales: poseen legitimidad, pero no poder o urgencia.

- Demandantes: al contrario de los anteriores, estos sí cuentan con urgencia, aunque no con poder y tampoco con legitimidad para manifestar sus necesidades, expectativas e intereses.

- Stakeholders expectantes: son los que cuentan con dos de los tres atributos. Pueden ser:

- Dominantes: son quienes cuentan con poder y legitimidad, pero no con urgencia.

- Dependientes: aquellos que poseen urgencia y legitimidad, mas no poder.

- Peligrosos: son los que tienen poder y urgencia, pero no legitimidad.

Para Ángel (2010: 493), existe un tercer grupo, mismo que se refiere a:

- Stakeholders definitivos: son aquellos grupos de interés que poseen los tres atributos: poder, legitimidad y urgencia. Tomando en 
consideración, que este modelo es dinámico, los stakeholders pueden pasar de ser de un tipo a otro, dependiendo de las diferentes circunstancias

Figura 5. Tipología de stakeholders. Elaboración propia, basado en Vaccaro

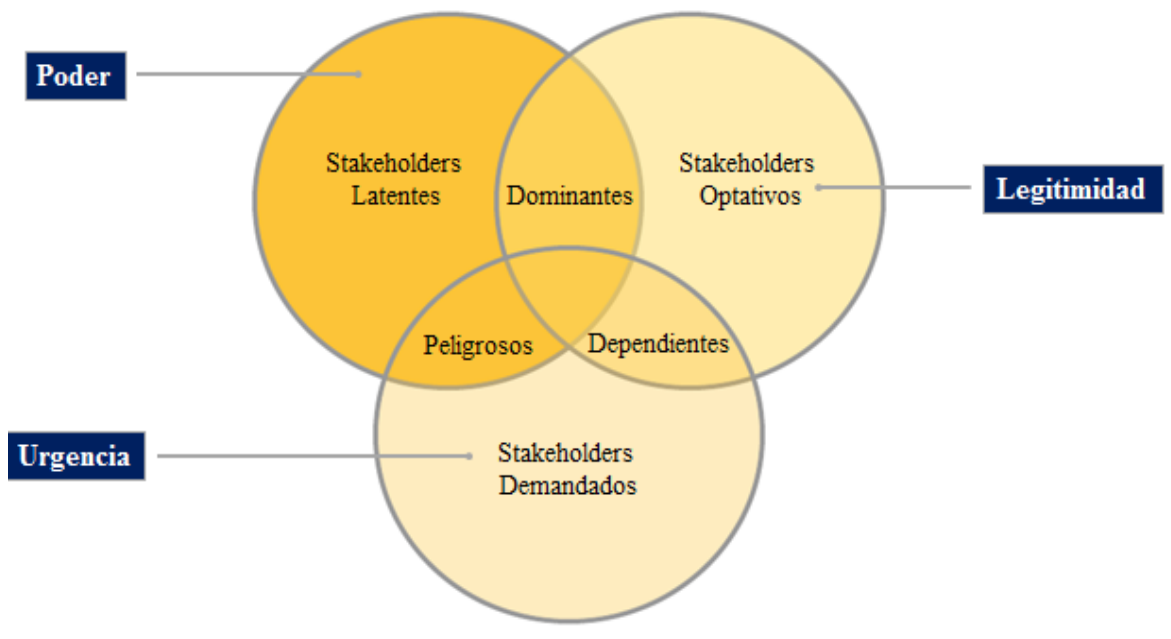

(2011: 3).

En definitiva, el empleo de cualquiera de las opciones para la clasificación de los stakeholders presentadas anteriormente, permitirá dar paso a la siguiente etapa de la identificación estratégica de los grupos de interés.

\subsection{Priorización de los stakeholders}

Es necesario seleccionar cuáles son los grupos más importantes y esenciales para la misma dependiendo los recursos que esta tenga. Esta etapa permite establecer y asignar los escasos activos, con el fin de generar el mayor impacto posible en la vinculación existente entre la empresa y sus grupos de interés.

Sin embargo, antes de efectuar la priorización, es preferible agrupar a cada uno de los stakeholders con el afán de unificar a aquellos que poseen características, necesidades y expectativas similares, para facilitar la selección de estos. Resulta primordial contar con un grupo de expertos que abarquen toda la problemática a partir de un enfoque global. 
Para Granda y Trujillo "los criterios de priorización son ponderables, intercambiables, adaptables y muchas veces únicos para cada organización o incluso para cada momento" (2011: 381). Sin embargo, a continuación, se propone una lista de criterios que permite guiar la ejecución de este proceso en base a la comunicación, entorno al establecimiento de una matriz basada en la importancia e influencia de los stakeholders sobre la institución o empresa.
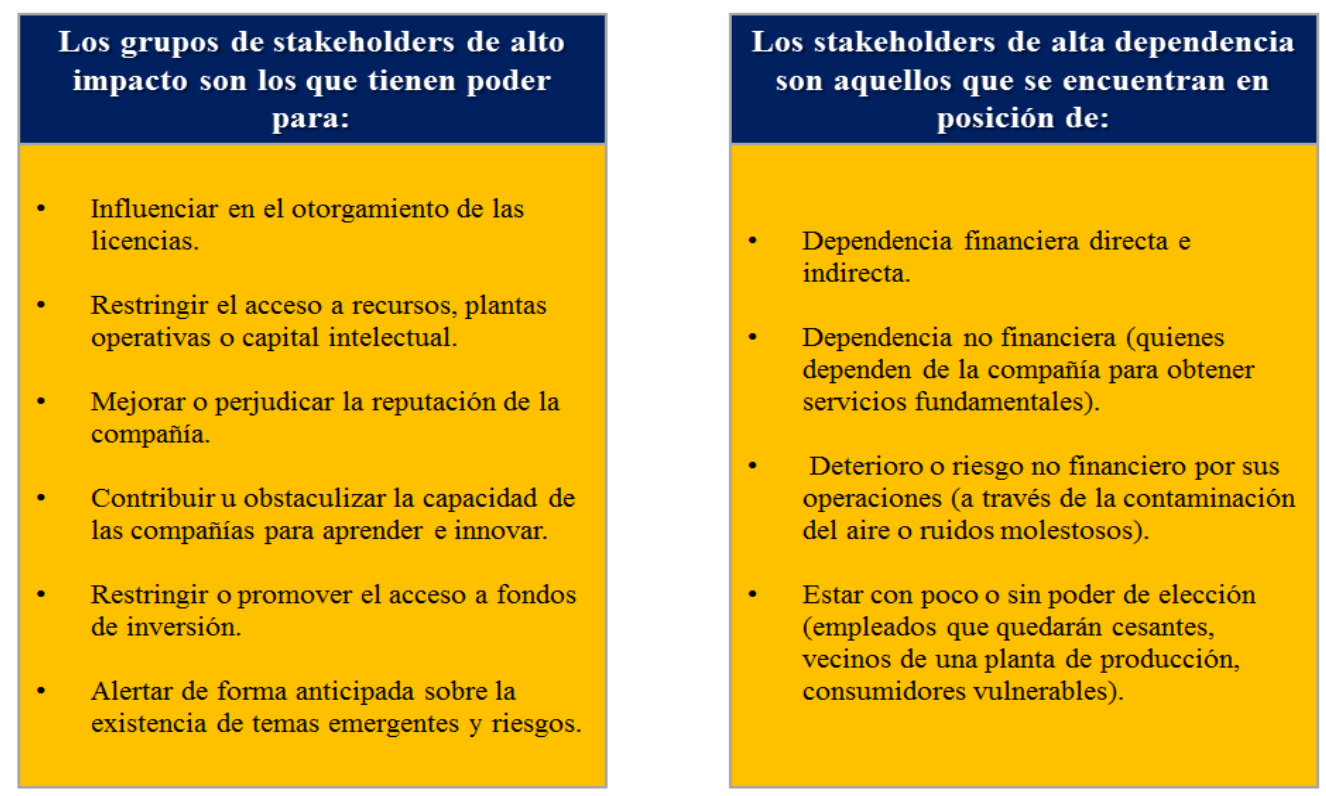

Figura 6. Criterios de priorización. Elaboración propia, basado en Krick et al. (2006: 44).

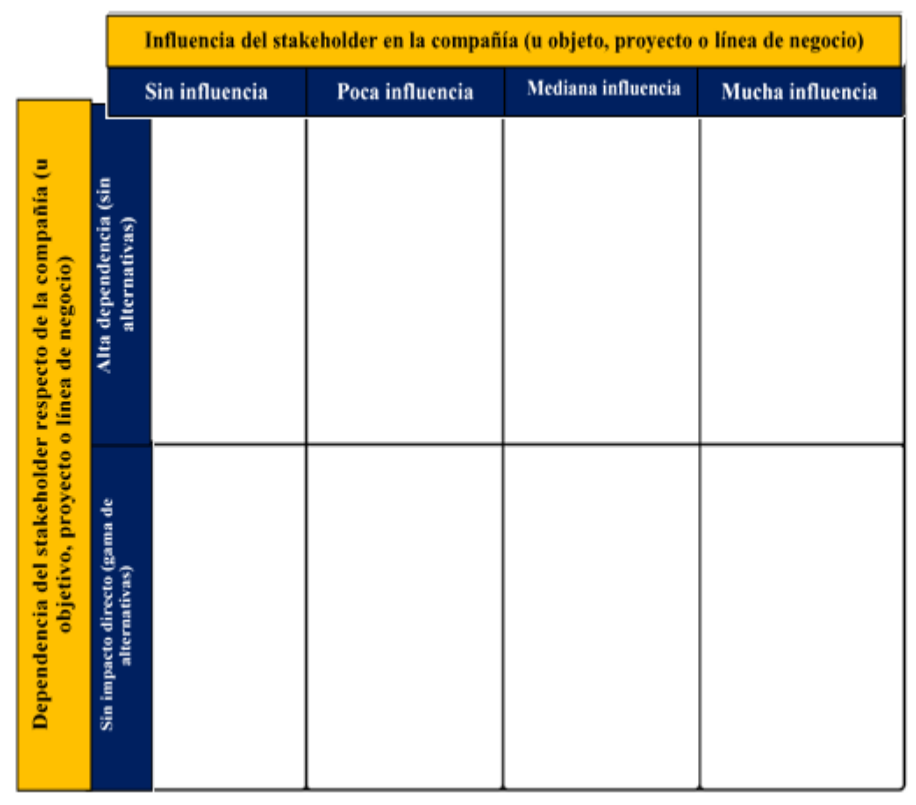

Figura 7. Matriz de importancia e influencia de los stakeholders. Elaboración propia, basado en Krick et al. (2006: 44) 


\subsection{Planificación}

Al buscar establecer una relación eficiente, sólida y fundamentada con los stakeholders es importante considerar efectuar una debida planificación, misma que garantizará la obtención de los resultados esperados, para evitar generar insatisfacción y un irreparable daño en la imagen y reputación de la empresa. Consecuentemente, es posible evidenciar que una adecuada gestión de los stakeholders no se encuentra relacionada solamente al análisis empírico de los mismos; de hecho, su consolidación se efectúa a partir de su planificación, con respecto a los objetivos estratégicos del negocio.

Para ello, se debe tomar en cuenta un plan de acción fundamentado en la comprensión y esclarecimiento de las necesidades y expectativas comunicacionales existentes, por parte de los stakeholders hacia la compañía; así como también la verificación en cuanto a disponibilidad de recursos y grado de compromiso organizacional, se refiere. Krick y otros afirman que esto facilitará el "desarrollar un enfoque de relación con alineación estratégica y eficiencia de recursos e iniciar el proceso de aprendizaje interno y convocatoria de las áreas y personas claves para que la relación con los stakeholders vaya más allá de las meras palabras" (2006: 49).

\subsection{Comunicación}

En la actualidad, las organizaciones deben ser sensatas y reflexivas en cuanto a la responsabilidad que implica la comunicación con sus respectivos grupos de interés; misma que deberá caracterizarse por ser sólida, fundamentada en valores y principios que beneficien su vínculo. Allí radica, la importancia del manejo comunicacional como proceso del modelo de gestión de los stakeholders; pues "las relaciones entre las empresas y sus grupos de interés son cada vez más elaboradas y suponen, cada vez más, interacciones entre los actores involucrados" (Strandberg, 2010: 7).

Es así, que el diálogo otorga más posibilidades a los stakeholders de influir dentro y fuera de la empresa, pues contribuye a su progreso continuo; al garantizar el desarrollo sostenible de las actividades de esta, 
por tanto, la clave se encuentra en la construcción conjunta de objetivos (Apolo, Murillo y García, 2014). Es por ello, que resulta esencial establecer un continuo intercambio de opiniones que permitan finiquitar acuerdos de colaboración, en beneficio de ambas partes, mediante el diálogo permanente con los grupos de interés con miras hacia reforzar el compromiso y la responsabilidad social (Casado, 2006; Orejuela, 2011; Rivera y Malaver., 2011).

Cabe mencionar también que, con el paso del tiempo se ha visto indispensable determinar los temas y herramientas fundamentales para construir un mecanismo de diálogo y compromiso que motive y mantenga el vínculo estratégico entre la compañía y sus stakeholders; además de contribuir con su desarrollo económico y financiero y por tanto la relevancia de la gestión de intangibles y su abordaje desde la comunicación corporativa (Báez et al., 2017)

Entonces, resulta relevante el mantener un proceso comunicacional con los distintos grupos de interés y se mencionan algunas ventajas, entre las que están:

- Mejor gestión en cuanto a situaciones de riesgo (crisis empresariales), se refiere.

- Identificación de temas relevantes para la organización.

- Incremento de la innovación empresarial, debido al desarrollo de nuevos procesos, productos y servicios, gracias a la información recopilada en el proceso de vinculación.

- Aumento de nivel de comprensión del contexto político, social, económico y ambiental actual y futuro; permitiendo identificar nuevos nichos de mercados y oportunidades de negocio.

- Mejora de la imagen y reputación corporativa.

\subsubsection{Selección de herramientas de diálogo}

Es esencial tomar en cuenta el nivel de importancia de cada uno de los grupos de interés, pues los menos relevantes serán gestionados de manera diferenciada, con el fin de incrementar su compromiso comunicacional, con respecto al vínculo existente entre ellos y la 
organización. Así pues, de acuerdo con Granda y Trujillo (2011) se pueden distinguir tres tipos de herramientas comunicacionales:

- Herramientas unidireccionales: son aplicables para aquellos grupos de interés menos importantes o con menor capacidad de compromiso para la compañía. Por lo general, busca controlar la información transferida hacia los grupos de interés, por medio del empleo de herramientas informativas como boletines.

- Herramientas bidireccionales: hace referencias a herramientas mucho más complejas, puesto que presentan la posibilidad de un intercambio de información, debido a que se pretende conocer e integrar las necesidades y expectativas de los grupos de interés en el desarrollo de las actividades de la organización; así pues, pueden ser herramientas de información activa o simplemente consultas. Es por ello, que resultan ser las más utilizadas, incluso para los niveles más críticos de los stakeholders, siempre y cuando se consideren sus beneficios y riesgos, a la hora de garantizar el éxito en la gestión empresarial.

- Herramientas integradoras: son las herramientas del nivel superior del modelo de gestión de los stakeholders, por lo que consiste en la integración, asesoramiento y participación directa en actividades de importancia empresarial; por lo que son estructuras realmente complejas, necesarias únicamente para las compañías que tratan a sus grupos de interés, como un elemento esencial dentro de su modelo de negocio.

\subsubsection{Relación e interacción: el diálogo}

El diálogo establecido por las instituciones con sus respectivos stakebolders ha tenido un gran avance, pues a partir de ser simplemente una buena idea se ha convertido en una práctica habitual ejecutada por varias empresas, que desean ser reconocidas por la sociedad en general; gracias a la cercanía existente entre las mismas y sus respectivos grupos de interés. De acuerdo a Torres (2009: 79), se ha llegado a profesionalizar esta etapa, por lo que se pueden apreciar, las siguientes: 
- Del diálogo multi-stakeholder al diálogo mono-stakeholder. hace referencia a las plataformas de diálogo simultáneo con diversos grupos de interés, aunque a medida en que la madurez del diálogo vaya incrementándose, será necesario el inicio de procesos más específicos con cada uno de ellos.

- Del diálogo generalista al diálogo temático: las compañías se han visto en la necesidad de organizar los asuntos a tratar, con el fin de que el tema clave resalte más que los otros.

- Del diálogo externo al diálogo interno: se evita que diálogo se produzca exclusivamente en determinados departamentos de la compañía, por lo que es importante que participen todas las áreas, para que este diálogo conozca a nivel institucional.

- Extensión geográfica del diálogo: la empresa tiene el deber de dar a conocer sus procesos de diálogo en los distintos lugares donde opera, pues la información obtenida puede llegar a ser más valiosa que cualquier otra.

- Del diálogo defensivo al diálogo integrador: las empresas más innovadoras están pasando de procesos de diálogo basados en la reputación (defensivos) a procesos de diálogo centrados en la búsqueda de oportunidades de negocio y selección de nuevos proyectos (integradores).

- Del diálogo simple a una mayor sofisticación de las herramientas: las compañías han dejado de emplear medios tradicionales para el diálogo, pues se encuentran empleando más y mejores herramientas para obtener información exacta y veraz sobre las necesidades y expectativas de los grupos de interés.

\subsection{Evaluación}

En vista que la evaluación es un factor clave en el desarrollo de cualquier proyecto, esta no es la excepción, pues la misma tiene repercusión directa en cuanto al éxito o fracaso de la gestión 
empresarial de la compañía, puesto que este proceso permite conocer los aciertos y errores cometidos a lo largo de la ejecución del modelo propuesto; convirtiéndose en el punto de partida para próximas prácticas. "En la práctica, evaluar facilita, por ejemplo, indagar el nivel de satisfacción y la imagen de los públicos; adecuar la comunicación masiva y directa para construir una mejor relación con ellos; conocer sus prioridades, expectativas y necesidades y entonces posicionar los objetivos" (Álvarez, 2011: 11). De este modo, la evaluación ayuda a las organizaciones a alinear su propia imagen en base a las expectativas de sus grupos de interés, es por ello por lo que se ha convertido en un proceso efectivo, a la hora de comprender la manera en cómo los demás perciben sus acciones y lo que estos esperan de la misma. Ávila indica:

"La evaluación es un proceso que genera información, por lo que es de especial relevancia detenernos a pensar qué es lo que se hace con esta información, cómo es sistematizada, pero, sobre todo, cómo es interpretada y comunicada con el fin de que tenga una utilidad práctica" (2009: 1).

\subsubsection{Actividades de seguimiento para la consolidación de la confianza en los stakeholders}

El hecho de identificar, planificar, comunicar y relacionar a los stakeholders con una determinada organización, constituye una parte integral del modelo de gestión propuesto, pues el mismo permite ofrecer una retroalimentación a aquellos que intervinieron en el proceso mencionado, promoviendo el mantenimiento continuo y permanente del vínculo existente. Para Krick y otros "los informes públicos pueden resultar esenciales para informar a distintos tipos de stakeholders acerca del desempeño de la compañía, pero, también, pueden interpretarse como una contribución al debate global sobre la evolución del rol de las empresas en la sociedad" (2006: 113).

Es así, que propone ciertas herramientas que permitan mantener informados a los stakeholders:

- Conversaciones individuales.

- Seguimiento presencial o telefónico. 
- Cartas de agradecimiento que resumen los resultados y compromiso de mejora continua.

- Actividades regulares de información.

De esta manera, la aplicación por parte de las empresas de ciertos parámetros implica el incremento de la confianza sobre la manera en cómo se gestionan las organizaciones, consiguiendo un impacto directo sobre la manera en la que los diversos stakeholders perciben y valoran a las compañías, contribuyendo al desarrollo organizacional, al convertirse en un valor agregado que le permite diferenciarse de la competencia y fortalecerse a nivel general en el mercado.

En definitiva, resulta vital la ejecución de los procesos mencionados anteriormente, se han convertido en un factor poderoso, a la hora de generar confianza en los grupos de interés, pues al desempeñarlos en base a estándares de alta calidad, permiten el cumplimiento de varios criterios, correspondientes al incremento de credibilidad y fortalecimiento de la confianza. Así pues, para Strandberg:

"La interacción cara a cara y la capacidad de desarrollar las relaciones individuales son, generalmente, el método más eficaz para la construcción de confianza y la credibilidad de la empresa. A su vez, el hecho de crear confianza es crucial para lograr el éxito a largo plazo" (2010: 9).

\section{Referencias}

Acuña, A. (2012). La Gestión de los Stakeholders. Análisis de los diferentes modelos. Buenos Aires: Universidad Nacional del Sur.

Agüero, A.; Carbonell, M. y Martínez, J. (2006). Los Stakeholders y la acción social de la empresa. Madrid: Ediciones Jurídicas y Sociales S.A. Álvarez, A. (2011). Medición y Evaluación en Comunicación. Instituto de Investigaciones en Relaciones Públicas, (2), 1-112.

Ángel, J. (2010). Manejo de stakeholders como estrategia para la administración de proyectos de desarrollo en territorios rurales. Agronomía Colombiana, 28(3), 491-499.

Ávila, P. (2009). La Importancia de la Retroalimentación en los Procesos de Evaluación. Queretaro: Universidad del Valle de México. 
Apolo, D., Báez V., Pauker, L. y Pasquel, G. (2017). Gestión de

Comunicación Corporativa: consideraciones para el abordaje de su estudio y práctica. Revista Latina de Comunicación Social, 72, 521 a 539. doi: 10.4185/RLCS-2017-1177.

Apolo, D., Murillo, H. y García, G. (2014). Comunicación 360: herramientas para la gestión de comunicación interna e identidad.

Quito: Facultad de Comunicación-Universidad Tecnológica Equinoccial.

Báez, V., Pauker, L., Pasquel, G. y Apolo, D. (2017). Comunicación Corporativa e intangibles. En Túñez López, M y Costa-Sánchez, C. Gestionar comunicación. Avances y experiencias. Cuadernos Artesanos de Comunicación, $\mathrm{n}^{\circ} 127$, pp. 33 a 51. La Laguna (Tenerife): Latina doi: $10.4185 / \operatorname{cac} 127$.

Caballero, G. (2007). La Importancia de los Stakeholders de la Organización: Un Análisis Empírico aplicado a la Empleabilidad del Alumnado de la Universidad Española. Investigaciones Europeas de Dirección y Economía de la Empresa, 13(2), 13-32.

Casado, F. (2006). La RSE ante el espejo. Zaragoza: Prensas Universitarias de Zaragoza.

Clarkson, M. (1995). A Stakeholder Framework for Analyzing and Evaluating Corporate Social Performance. Academy of Management Review, 20(1), 92-117. doi: 10.5465/AMR.1995.9503271994.

Clemens, B. y Gallagher, S. (2003). Stakeholders for environmental strategies:

the case of the emerging industry in radioactive scrap metal treatment.

Londres: Greenleaf Publishing.

Fernández, J. y Bajo, A. (2012). La Teoría del Stakeholder o de los

Grupos de Interés, pieza clave de la RSE, del éxito empresarial y de la sostenibilidad. Revista Internacional de Investigación en Comunicación, 6(6), 130-143. doi: 10.7263/ADR.RSC.006.07.

Freeman, R. (1984). Strategic management: a stakeholder approach. Maryland: Pitman

Freeman, R., Harrison, S., Wicks, C., Parmar, L., y De Colle, S. (2010). Stakeholder theory: The state of the art. Cambridge: University Press.

González, E. (2007). La teoría de los stakeholders. Un puente para el desarrollo práctico de la ética empresarial y de la responsabilidad social corporativa. Veritas, 17(1), 205-224.

Granda, G. y Trujillo, F. (2011). La Gestión de los Grupos de Interés (Stakeholders) en la Estrategia de las Organizaciones. Dialnet. (381), 71-76. 
Krick, T., Forstater, M., Monaghan, P. y Sillanpää, M. (2006). El compromiso con los stakeholders. AccountAbility, United Nations Environment Programme. Canada: Stakeholder Research Associates.

Lafuente, G. y Luciano, P. (2011). La gestión de los grupos de interés: una reflexión sobre los desafíos a los que se enfrentan las empresas en la búsqueda de la sostenibilidad empresarial. Revista de Métodos Cuantitativos para la Economía y la Empresa, (11), 71-90.

Lazzari, L. y Moulia., P. (2015). Responsabilidad Social de las Organizaciones: Avances y Propuestas en América Latina. Trujillo: Universidad Católica Los Ángeles de Chimbote.

Mitchell, R., Bradley, R. y Donna, W., (1997). Toward a theory stakeholder identification and salience: defining the principle of who and what really counts. Academy of Management Review, 22(4), 856-886.

Orjuela, S. (2011). La Comunicación en la gestión de la Responsabilidad Social Empresarial, Correspondencias y Análisis, (1), 137-156.

Orozco, J. y Ferré, C. (2011). Los Stakeholders de las Empresas de Comunicación en el Ámbito de la Responsabilidad Social Corporativa. Barcelona: Universidad Autónoma de Barcelona.

Pasquel, G., Báez, V., Pauker, L. y Apolo, D. (2015). Percepción, activos intangibles y stakeholders: modelo para el análisis de imagen corporativa. Revista Mediterránea de Comunicación, 7(1), 1-17. doi: http://dx.doi.org/10.14198/MEDCOM2016.7.1.10

Rivera, H. y Malaver., M. (2011). La organización: los stakeholders y la responsabilidad social. Bogotá: Universidad del Rosario.

Strandberg, L. (2010). Cátedra "la Caixa" de Responsabilidad Social de la Empresa y Gobierno Corporativo. IESE Business School, 10(1), 126.

Torres, D. (2009). Acciones empresariales estratégicas. El diálogo con los stakeholders. Telos, (79). Disponible en: https://telos.fundaciontelefonica.com/telos/articulocuaderno.asp @idarticulo=8\&rev=79.htm.

Vaccaro, A. (2011). Identificar y priorizar stakeholders, clave para una buena gestión de crisis. Insights, 1-4. 


\title{
El capital social de las organizaciones en el contexto digital de la web 2.0
}

\author{
Roberto Alejandro López Novelo \\ Universidad Anáhuac \\ Raúl Santos Morales \\ Universidad Anáhuac
}

PARA CITAR: López Novelo, R., Santos Morales, R. (2018). El capital social de las organizaciones en el contexto digital de la web 2.0. En Túñez-López, M., Costa-Sánchez, C. y Valdiviezo, C. (Eds.), (2018). Comunicación Organizacional en entornos online. Gestión, actores y recursos. Cuadernos Artesanos de Comunicación, no 149 (pp. 53-74). La Laguna (Tenerife): Latina.

\section{Resumen}

La aparición, masificación e internacionalización de Internet provocó un tremendo cambio mediático que, a muchas organizaciones, aún en pleno siglo XXI, les ha costado encarar de manera adecuada las posibilidades que el actual contexto digital permite. Tras realizar un repaso a las visiones clásicas y tecnológicas del capital social, se establece un modelo de comunicación digital que le permitirá a cualquier organización, potencializar el capital social latente que posee a través de diversas conversaciones e interacciones que se pueden suscitar en la web 2.0, haciendo más visible el papel que pueden desempeñar como elementos de cambio y transformación social.

Palabras clave: capital social, organizaciones, comunicación, Internet, web 2.0. 
El capital social es un concepto que en la actualidad es utilizado para explicar diversos fenómenos que van desde lo social, político, económico, cultural, administrativo, educativo cultural, hasta lo tecnológico y lo digital. Y es precisamente el contexto digital el que ha ocasionado que una vez más este concepto esté vigente.

Los elementos que constituyen al capital social en la actualidad, pueden ser rastreados en autores como Alexis de Tocqueville, Lyda Judson Hanifan, Karl Marx, Émile Durkheim y John Dewey, pero es Pierre Bourdieu quien desarrolla el concepto en 1973 y posteriormente, lo redefine en 1983.

Para entender las dimensiones y los retos que se desprenden del capital social en el contexto digital actual, en un primer momento se hace un repaso de los aportes realizados por el mismo Bourdieu y otros autores que han ayudado a construir el término como James Samuel Coleman, Robert Putnam, Simon Szreter, Michael Woolcock, Francis Fukuyama, Janine Nahapiet y Sumantra Goshal.

En un segundo momento, se abordan los planteamientos de investigadores que vinculan al capital social con el contexto sociotécnico actual, en el que las Tecnologías de Información y Comunicación (TIC) son básicas para el desarrollo de prácticas sociales, lúdicas, profesionales u organizacionales, por mencionar tan sólo algunos ejemplos, como Nan Lin, Marleen Huysmann, Vulquer Wulf, James E. Katz, Ronald Rice, Anabel Quan y Barry Wellman.

Posteriormente, se abordan los cambios que trajo Internet en términos tecnológicos, así como los diferentes tipos de webs y niveles de comunicación que emanan de ellos, además de las diferentes posibilidades de conversación e interacción que ofrece el contexto digital para establecer las categorías, formas, alcance y tipos de capital social, que finalmente son plasmados en un modelo centrado en ocho principios de comunicación digital y tres ejes vitales para el desarrollo del capital social. 


\section{Fundamentos teóricos del capital social: visiones clásicas}

Los primeros acercamientos al concepto de capital social, los encontramos en Pierre Bourdieu, quien define al capital social como "un agregado potencial o actual de los recursos que se acumulan en un individuo o grupo social a través de la generación de relaciones o contactos durables más o menos institucionalizados y de mutuo acuerdo y reconocimiento" (Bourdieu, 1985: 248).

Lo anterior permite inferir qué para Bourdieu, el capital social, se convierte en un vehículo a través del cual las personas pueden acceder a una serie de recursos intangibles acumulados en una red, incrementar su capital cultural y económico; lo importante aquí, es observar el peso que tiene el proceso de sociabilidad entre los miembros de un grupo social que se encuentran relacionados de alguna manera.

Así, "para Bourdieu, la densidad y la durabilidad de los lazos (conexiones) son vitales ya que el capital social representa un agregado actual o potencial de los recursos que surgen de la participación en una red durable" (López Novelo, 2011: 64). El capital social entonces está condicionado por la amplitud y alcances de las relaciones - sociales, culturales, profesionales, etc. - que una persona construya y del uso de los recursos que se desprendan de la red de relaciones. De esta manera, el valor de las relaciones de un individuo depende del volumen de contactos y de capital cultural, económico o social que se pueda gestionar.

Después de Pierre Bourdieu, aparecen nuevos aportes al concepto de capital social y estos son realizados por James S. Coleman, quien define al capital social:

"Como una variedad de entidades que tienen dos elementos en común: todos ellos consisten en algunos aspectos de la estructura social y facilitan algunas acciones de los actores que forman parte de dicha estructura social. Para Coleman, el capital social puede ser cualquier cosa, situación, etc., que facilite la acción individual o colectiva en una sociedad, desprendida de las redes sociales, de reciprocidad y de verdad" (López Novelo, 2011: 65). 
De esta manera, se entiende que el capital social es un recurso intangible que, al ser utilizado adecuadamente, permite la consecución de cualquier objetivo individual o colectivo. Esto se logra gracias a la presencia de dos elementos fundamentales: la reciprocidad y la confianza en los otros miembros de una estructura o grupo social. Así, en el capital social, se benefician todos los miembros de una red, y no, como ocurre en otros tipos de capital, como el económico donde únicamente se benefician las personas que invierten.

De acuerdo con Coleman, el capital social se genera cuando una persona decide hacer algo por otra, esperando qué en un futuro, esta se comporte de manera recíproca. De este modo, en un periodo de tiempo corto, el capital social se convierte en una obligación para cada uno de los miembros de una red.

Después de James. S. Coleman, aparece en el escenario académico Robert Putnam, quién establece que las normas de reciprocidad que permean a la sociedad de forma general son fundamentales para el desarrollo social. De acuerdo con Putnam (1993: 167), el capital social tendría que definirse como "las ventajas que se desprenden de las organizaciones sociales como la confianza, las normas y las conexiones, que permiten la eficiencia de la sociedad al facilitar las acciones coordinadas".

Un elemento fundamental para que exista una dinámica relacional altamente productiva es la confianza, ya que una vez que se construye, el trabajo colectivo es más sencillo y funcional. De este modo "el capital social se refiere a los rasgos de las organizaciones sociales como las conexiones, normas y la confianza que facilitan la coordinación y cooperación para obtener beneficios mutuos" (Putnam, 1995: 67).

Desde la perspectiva de Robert Putnam, existen dos elementos fundamentales para entender al capital social: el capital social de lazos fuertes (bonding social capital) y el capital social de puente (bridging social capital). El primero, hace referencia a los vínculos establecidos entre grupos de personas homogéneas; y el segundo, se refiere a los vínculos que se generan entre grupos de individuos heterogéneos. 
Para Putnam, la constitución del capital social dentro de una comunidad está asociada con redes sociales densas y horizontales, estas redes hoy se potencializan (con prácticas positivas o negativas) con la presencia de las TIC. Dentro de estas redes existen altos niveles de confianza, reciprocidad e identidad, que sirven para la solución de problemas de carácter colectivo, sean económicos, políticas o sociales (López Novelo, 2011: 70).

Posterior a Putnam, Simon Szreter y Michael Woolcock, aportan una nueva forma de capital social: el vinculante. Este tipo de capital social hace referencia a "las normas de respeto y redes de relaciones de confianza entre personas que interactúan a través de gradientes de poder o autoridad explicita, formal o institucionalizada en la sociedad" (Szreter y Woolcock, 2004: 655), por lo que el capital social de vinculación o vinculante tiene que ver con la forma en la que se fortalecen las relaciones de capital social de puente, es decir, entre individuos, grupos e instituciones heterogéneos que se saben diferentes en términos de poder y recursos institucionales (Szreter y Woolcock, 2004).

Otro autor que realiza aportes significativos a la construcción del concepto de capital social es Francis Fukuyama, que establece que "el capital social es una capacidad que se origina de la prevalencia de la confianza en la sociedad o en ciertas partes de ella" (Fukuyama, 1996: 26), por lo que, para la construcción, distribución y aprovechamiento del capital social es necesario que en un grupo social se generen valores comunes como la lealtad, la honestidad y dependencia; elementos que en su conjunto conforman la confianza.

Para finalizar esta primera fase teórica, se presentan los aportes de Nahapiet y Ghosal, quienes abordan al capital social desde tres dimensiones fundamentales: estructural, relacional y cognitiva.

La dimensión estructural se refiere a la capacidad que tienen los individuos de establecer relaciones o lazos débiles y fuertes con otros individuos dentro de un sistema, y está conformada por los nexos de red (proporcionan acceso a recursos de la red), la configuración de la red y la apropiabilidad. La dimensión relacional se enfoca en el carácter 
de las conexiones entre individuos. Y la dimensión cognitiva se refiere al interés común o la actitud de los miembros de una red de querer compartir sus conocimientos dentro de una organización, basados en un principio de confianza mutua (López Novelo, 2011).

De acuerdo con estos autores, si se estudia al capital social bajo estos tres elementos, entonces su comprensión y aplicación en diversos contextos, será más clara.

Tabla 1. Construcción teórica del concepto de capital social.

\begin{tabular}{|l|l|}
\hline \multicolumn{1}{|c|}{ Autor } & \multicolumn{1}{|c|}{ Definición } \\
\hline Bourdieu & $\begin{array}{l}\text { Agregado potencial y actual de los recursos que se } \\
\text { encuentranacumulados dentro de una red y se } \\
\text { aprovecha por los individuos que la conforman. }\end{array}$ \\
\hline Coleman & $\begin{array}{l}\text { Recurso intangible que permite el logro de metas y } \\
\text { objetivos de manera individual y colectiva. }\end{array}$ \\
\hline Putnam & $\begin{array}{l}\text { Coordinación y cooperación entre organizaciones } \\
\text { que permiten la obtención de beneficios mutuos. }\end{array}$ \\
\hline $\begin{array}{l}\text { Szreter y } \\
\text { Woolcock }\end{array}$ & $\begin{array}{l}\text { Normas de respeto y redes de relaciones de } \\
\text { confianza entre personas que interactúan a través de } \\
\text { gradientes de poder o autoridad explicita, formal o } \\
\text { institucionalizada en la sociedad. }\end{array}$ \\
\hline Fukuyama & $\begin{array}{l}\text { Resultado de la construcción de confianza entre } \\
\text { individuos que conforman a la sociedad. }\end{array}$ \\
\hline $\begin{array}{l}\text { Nahapiet y } \\
\text { Goshal }\end{array}$ & Dimensión estructural, relacional y cognitiva. \\
\hline
\end{tabular}

Fuente: Elaboración propia a partir de Bourdieu (1985), Coleman (1993), Putnam (1993, 1995), Szreter y Woolcock (2004), Fukuyama (1996), Nahapiet y Goshal (1998).

Luego de plantear el proceso de construcción teórico del capital social, con autores como Bourdieu, Coleman, Putnam, Fukuyama, Nahapiet y Goshal, en las próximas líneas se presentan las propuestas de vinculación del capital social con las Tecnologías de Información y Comunicación (TIC), en el contexto sociotécnico actual, realizadas por Nan Lin, Marleen Huysmann, Vulquer Wulf, Philip Howard, James E. Katz, Ronald Rice, Anabel Quan y Barry Wellman. 


\section{Tecnologías de información y comunicación (TIC) y capital social}

El interés en vincular al capital social con las Tecnologías de Información y Comunicación (TIC) se sustenta en el hecho de que, en el contexto actual, Internet se presenta como un espacio social en el que millones de personas alrededor del planeta establecen diversos tipos de relaciones a partir de redes sociodigitales, y estas relaciones son de diversa índole: relación, colaboración, participación, conocimiento, trabajo, entre otras.

Internet es una estructura tecnosocial que hoy en día está presente en la dinámica relacional de los individuos, y, si se parte de la idea de que el capital social se sustenta en la creación de relaciones y redes sociales, basadas en la reciprocidad, la confianza, la colaboración, etc., entonces se puede pensar que Internet tiene potencial para la construcción de este tipo de capital.

Para Nan Lin (1999), el capital social se fundamenta en la premisa que la inversión en capital social genera retornos en términos de un mercado que puede ser económico, político, laboral o comunitario, y que el concepto debe entenderse como un activo social o colectivo y como el capital que se genera a través de las relaciones sociales “... puede ser definido como los recursos que se encuentran en una estructura social, que son usados y movilizados con un objetivo claro" (Lin, 1999: 35). En esta definición se observan de manera clara tres elementos básicos: la estructura de la red, el uso y la movilidad del capital social. Si pensamos en Internet en un primer momento y después en las redes sociodigitales que se encuentran inmersas en este nuevo espacio social, podemos observar cómo estos elementos están presentes en las dinámicas de los usuarios de la red.

Se puede establecer que Internet es una tecnología en la que se concentran grandes cantidades de capital social que pueden ser aprovechados no sólo por los millones de usuarios que día a día utilizan esta red, sino también por diversas organizaciones que hoy encuentran en este espacio social numerosas oportunidades para generar diversos tipos de capital, entre ellos el social. 
Luego de las propuestas de Lin, a continuación, se presentan algunos de los planteamientos más significativos de Marleen Huysmann y Vulquer Wulf. De acuerdo con estos autores, "el capital social es un concepto que hace referencia al establecimiento de lazos de buena voluntad, apoyo mutuo, normas, confianza social y un sentimiento de mutua obligación derivada de las personas" (Hysmann y Wulf, 2004: 1). Ellos plantean dos preguntas básicas con respecto a este tipo de capital: ¿el capital social se genera cuando las conexiones entre personas se llevan a cabo cuando se usan las Tecnologías de Información y Comunicación (TIC)? y ¿cómo afectan las TIC al capital social? Estos cuestionamientos son adecuados para el estudio de la relación existente entre Tecnologías de Información en Comunicación e Internet, ya que a través de ellos se pretende determinar si el capital social se genera y distribuye también en las relaciones que se llevan a cabo en el ciberespacio.

Philip Howard establece que se debe considerar a Internet y sus correspondientes entornos digitales como un nuevo espacio solidario y social, en el que se desarrollan nuevas formas de producción y consumo cultural, y se cuestiona ¿si la gente conoce de verdad a gente nueva y aprende cosas nuevas en internet, o simplemente se limitan a ampliar y cosificar sus redes sociales y sus intereses ya existentes? (Howard, 2005).

Para este autor, Internet se presenta como un espacio en donde las personas no sólo adquieren conocimientos, sino que también los generan y los comparten, establecen lazos fuertes o bien de puente con algunos grupos sociales, lo que a la postre permite la creación de capital social.

En este recorrido, ahora damos pauta a las ideas de James E. Katz y Ronald Rice respecto al vínculo capital social-TIC, quienes en un primer momento establecen que Internet "crea capital social individual y colectivo, crea capital social tradicional, permite la creación de nuevas formas de capital social y contribuye a la aparición de nuevas formas de interacción social" (Katz, 2005: 328-343). Para estos autores, Internet se presenta como un espacio social en el que se promueve la 
participación, la colaboración, la relación y la expresión social, donde el capital social encuentra un campo fértil para su desarrollo. Campo que en los últimos años ha empezado a ser aprovechado tanto por los usuarios como diversas organizaciones que tienen presencia en el contexto digital.

Según Katz y Rice (2005), lo que está sucediendo con Internet es que las personas no sólo están trasladando al ciberespacio sus actividades, también están ampliando sus posibilidades de acceder a nuevas maneras de pensar, de interconectarse y de actuar. Situación que tiene importantes implicaciones para la creación de capital social.

Para Anabel Quan y Barry Wellman, Internet es un espacio en el que se desarrollan nuevas formas de comunicación y de relación social e identifican tres aproximaciones conceptuales sobre las relación capital social e Internet:

1. Internet transforma el capital social.

2. Internet disminuye el capital social.

3. Internet da soporte al capital social (Quan y Wellman en Huysman y Wulf, 2004: 116).

Para estos autores, Internet es un espacio social en el que las personas crean comunidades virtuales, a través del uso de variados entornos y aplicaciones digitales que permiten la relación, colaboración e interacción social. Así, Internet no solo provee una nueva esfera para la comunicación, también ayuda al establecimiento de nuevas formas de relación social, que con el paso del tiempo salen del ciberespacio y continúan en el espacio real (ver Tabla 2).

Una vez concluido este recorrido teórico sobre la construcción del concepto de Capital Social y su vinculación con las Tecnologías de Información y Comunicación (TIC), particularmente con Internet, en el siguiente punto se aborda el contexto digital que existe actualmente para las organizaciones. 
Tabla 2. Capital social y TIC.

\begin{tabular}{|l|l|}
\hline \multicolumn{1}{|c|}{ Autor } & \multicolumn{1}{c|}{ Definición } \\
\hline Lin & $\begin{array}{l}\text { Recursos que se encuentran en una estructura social, } \\
\text { que son usados y movilizados con un objetivo claro. }\end{array}$ \\
\hline $\begin{array}{l}\text { Huysmann y } \\
\text { Wulf }\end{array}$ & $\begin{array}{l}\text { Establecimiento de lazos de buena voluntad, apoyo } \\
\text { mutuo, normas, confianza social y un sentimiento de } \\
\text { mutua obligación derivada de las personas. }\end{array}$ \\
\hline Howard & $\begin{array}{l}\text { Internet se presenta como un espacio que permite la } \\
\text { creación de capital social. }\end{array}$ \\
\hline Katz y Rice & $\begin{array}{l}\text { Internet permite la creación de nuevas formas de } \\
\text { capital social y contribuye a la aparición de nuevas } \\
\text { formas de interacción social. }\end{array}$ \\
\hline $\begin{array}{l}\text { Quan y } \\
\text { Wellman }\end{array}$ & $\begin{array}{l}\text { Internet es un espacio en el que se desarrollan nuevas } \\
\text { formas de comunicación y de relación social. }\end{array}$ \\
\hline
\end{tabular}

Fuente: Elaboración propia a partir de Lin (1999), Huysman y Wulf (2004), Howard (2005), Katz y Rice (2005), Quan y Wellman (2002).

\section{Internet y capital social}

La aparición, masificación e internacionalización de diversos medios como la radio, el cine y la televisión y sus respectivos dispositivos tecnológicos, empezaron a generar entornos sensoriales y cognitivos que alteran los sentidos y patrones de percepción, por lo que las estructuras de los medios, sus contenidos e impacto se volvieron tema de investigación desde los años 60 a través del trabajo de Marshall McLuhan, Neil Postman y Walter Ong (Scolari, 2015), pero Internet transformó todo el entorno mediático que existía anteriormente al incluir múltiples canales y espacios, provocando nuevos tipos de experiencias, interacciones y por supuesto, conversaciones, por lo que la comunicación empezó a sufrir una transformación notable en sus elementos, objetivos, discursos, procesos, intereses, beneficios y pensamientos, logrando establecer diferentes niveles y por lo tanto, diferentes tipos de interacciones que han caracterizado a la web $1.0 y$ 2.0, y ahora, empiezan a caracterizar a la web 3.0, pero debemos recalcar que la web 3.0 está alejada del concepto de la web semántica, una web automatizada, cualitativa, extendida, extremadamente personalizada y autogestionada a través de la nube, propuesto por ingenieros, desarrolladores y programadores, debido a que sigue 
enfocada en el receptor o usuario para definir el significado de las palabras y facilitar contenidos portadores de significados adicionales con la finalidad de encontrar respuestas de manera más rápida y sencilla al almacenar información del usuario y combinarla con los contenidos existentes en diferentes canales y espacios de Internet (W3C, 2012; Küster y Hernández, 2013)(ver tabla 3).

Tabla 3. Niveles de comunicación en internet.

\begin{tabular}{|l|l|l|l|}
\hline \multicolumn{1}{|c|}{ Características } & \multicolumn{1}{|c|}{$\begin{array}{c}\text { Nivel I } \\
\text { (Web 1.0) }\end{array}$} & \multicolumn{1}{c|}{$\begin{array}{c}\text { Nivel II } \\
\text { (Web 2.0) }\end{array}$} & \multicolumn{1}{|c|}{$\begin{array}{c}\text { Nivel III } \\
\text { (Web 3.0) }\end{array}$} \\
\hline Elemento principal & $\begin{array}{l}\text { Emisor del } \\
\text { mensaje }\end{array}$ & $\begin{array}{l}\text { Receptor del } \\
\text { mensaje }\end{array}$ & $\begin{array}{l}\text { Emisor y } \\
\text { receptor del } \\
\text { mensaje }\end{array}$ \\
\hline Objetivo & Informar & Conversar & Construir \\
\hline Discurso & $\begin{array}{l}\text { Monólogo } \\
\text { (unidireccional) }\end{array}$ & $\begin{array}{l}\text { Diálogo } \\
\text { parcialmente } \\
\text { bidireccional } \\
\text { y/o } \\
\text { multidireccional) }\end{array}$ & $\begin{array}{l}\text { Diálogo } \\
\text { (completamente } \\
\text { bidireccional } \\
\text { y/o } \\
\text { multidireccional) }\end{array}$ \\
\hline Proceso & $\begin{array}{l}\text { Transmisión } \\
\text { de información } \\
\text { y mensajes }\end{array}$ & $\begin{array}{l}\text { Interacción } \\
\text { de información } \\
\text { y mensajes }\end{array}$ & $\begin{array}{l}\text { Concientización } \\
\text { de información } \\
\text { ymensajes }\end{array}$ \\
\hline Interés & $\begin{array}{l}\text { Fidelidad } \\
\text { de la } \\
\text { información }\end{array}$ & $\begin{array}{l}\text { Retroalimentación } \\
\text { de la información }\end{array}$ & $\begin{array}{l}\text { Co-construcción } \\
\text { de la } \\
\text { información }\end{array}$ \\
\hline Beneficios & Difusión social & $\begin{array}{l}\text { Participación } \\
\text { social }\end{array}$ & Consenso social \\
\hline Pensamiento & Lineal & Dinámico & Productivo \\
\hline
\end{tabular}

Fuente: Elaborada a partir de Nosnik, A. (2013).

Desde su nacimiento, Internet se convirtió en un catalizador social. La comunicación de la web 1.0 difundió socialmente los mensajes de las organizaciones, la comunicación de la web 2.0 ha tratado de generar participación social en los receptores a través de ciertos mensajes, mientras que la comunicación de la web 3.0, pretende generar consensos sociales a partir de cierto tipo de mensajes.

Por lo que el potencial de la web 3.0 no radica en sus características de programación y desarrollo -lo semántico, lo predictivo y lo artificialmente inteligente-, sino en la construcción, concientización y 
consenso social que pueden generar las organizaciones, es decir, en el capital social que puedan desarrollar dentro de un contexto digital.

La masificación de la web 1.0, generó el gran error de llevar al mundo digital los mismos métodos y modelos de comunicación que usaban en la radio y la televisión, por lo que el objetivo era informar o dar a conocer algo en lugar de comunicar o poner algo en común.

También se buscaba transmitir y difundir mensajes de manera unidireccional en lugar de conversar y retroalimentar de manera parcialmente bidireccional y/o multidireccional, por lo que Internet, en su formato 1.0, se inundó principalmente de una comunicación lineal basada en el emisor del mensaje -las organizaciones, sus productos y/o servicios- en lugar de tener una comunicación dinámica basada en el receptor -las personas vinculadas a esas organizaciones, productos y/o servicios-, puesto que importaban más las condiciones de elaboración y transmisión de mensajes en lugar de las condiciones de interacción, influencia y mutuo afecto entre los participantes de los procesos de comunicación vía internet como sucede en la web 2.0, de tal manera, que las posibilidades de las organizaciones con la web 3.0 recaen no sólo en adoptar nuevas tecnologías o en el caso de Internet, en utilizar nuevos canales y espacios digitales de la web, sino en adoptar nuevas conductas y nuevas interacciones (Shirky, 2008) que permitan construir diálogos completamente bidireccionales o multidireccionales.

Actualmente, existen al menos 35 posibilidades de conversar e interactuar en el contexto digital (ver tabla 4).

Tabla 4. Categorías de conversación e interacción digital.

\begin{tabular}{|l|l|}
\hline \multicolumn{1}{|c|}{ Categorías } & \multicolumn{1}{c|}{ Canales y espacios digitales } \\
\hline 1) Auto-medición y ejercicio & Fitbit, Runkeeper, Lose It!, Jawbone \\
\hline 2) Blogs y microblogs & Blogger, WordPress, Tumblr, Twitter \\
\hline 3) Conocimiento social & Reddit, Digg, Buzzfeed, Newsvine \\
\hline 4) Comentarios & $\begin{array}{l}\text { Disqus, Intensedebate, Livefyre, } \\
\text { Readboard }\end{array}$ \\
\hline 5) Comercio social & $\begin{array}{l}\text { Livingsocial, Thisnext, Kaboode, 8th } \\
\text { Bridge }\end{array}$ \\
\hline 6) Compra-venta de productos & $\begin{array}{l}\text { Amazon.com, eBay, Mercado Libre, } \\
\text { Bonanza }\end{array}$ \\
\hline
\end{tabular}




\begin{tabular}{|c|c|}
\hline 7) Conocimiento colaborativo & $\begin{array}{l}\text { Wikipedia, Fandom, Scholarpedia, } \\
\text { EOL }\end{array}$ \\
\hline 8) Conexiones en la vida real & Skout, Tinder, MeetMe, Bumble \\
\hline 9) Curaduría social & Pinterest, Fancy, Juxtapost, ScoopIt! \\
\hline 10) Discusiones y foros & $\begin{array}{l}\text { FanForum, 4Chan, Gaia Online, } \\
\text { Something Awful }\end{array}$ \\
\hline 11) Documentos y contenido & Prezi, Slideshare, Scribd, Docstoc \\
\hline $\begin{array}{l}\text { 12) Envío personalizado o } \\
\text { masivo de información }\end{array}$ & $\begin{array}{l}\text { Mailchimp, Sendblaster, Gmail, } \\
\text { Yahoo! Mail }\end{array}$ \\
\hline 13) Eventos & $\begin{array}{l}\text { Zvents, Upcoming, Eventful, } \\
\text { Eventbrite }\end{array}$ \\
\hline 14) Fondeo o crowdfunding & $\begin{array}{l}\text { Kickstarter, RocketHub, Indiegogo, } \\
\text { Crowdrise }\end{array}$ \\
\hline 15) Imágenes y álbumes de fotos & $\begin{array}{l}\text { Instagram, Flickr, Photobucket, } \\
\text { 500px }\end{array}$ \\
\hline 16) Influencia & Kred, Klout, Proskore, Social.IQ \\
\hline 17) Marcadores/etiquetas sociales & $\begin{array}{l}\text { StumbleUpon, Delicious, Pearltrees, } \\
\text { Pocket }\end{array}$ \\
\hline 18) Mensajería & Whatsapp, Telegram, Viber, WeChat \\
\hline 19) Mercado social & Groupon, Zaarly, WagJag, Etsy \\
\hline $\begin{array}{l}\text { 20) Mundos virtuales o } \\
\text { metaversos }\end{array}$ & $\begin{array}{l}\text { Second Life, Habbo, WoozWorld, } \\
\text { InWorldz }\end{array}$ \\
\hline 21) Música & $\begin{array}{l}\text { Spotify, Soundcloud, Last.FM, } \\
\text { Shazam }\end{array}$ \\
\hline $\begin{array}{l}\text { 22) Preguntas y respuestas de } \\
\text { expertos }\end{array}$ & $\begin{array}{l}\text { Quora, Answers.com, AllExperts, } \\
\text { Ask.FM }\end{array}$ \\
\hline $\begin{array}{l}\text { 23) Producción colaborativa de } \\
\text { proyectos y conocimiento }\end{array}$ & $\begin{array}{l}\text { Google Docs, Trello, Mural, } \\
\text { BaseCamp }\end{array}$ \\
\hline 24) Redes de nichos & Care2, Path, Diaspora, Dogster \\
\hline 25) Redes internas para empresas & Yammer, Tibbr, Chatter, Socialcast \\
\hline 26) Redes de trabajo y negocios & LinkedIn, Kentified, Xing, Viadeo \\
\hline 27) Redes de servicio & $\begin{array}{l}\text { Guru, Elance, Upwork, } \\
\text { Freelancer.com }\end{array}$ \\
\hline 28) Reseñas y ratings & Epinions, Bizrate, Yelp, Angie's List \\
\hline 29) Redes sociales & Facebook, Hi5, Bebo, Gloogle+ \\
\hline 30) Tendencias sociales & Weebly, Pump.io, Pasted, Plurk \\
\hline 31) Transmisiones en vivo & $\begin{array}{l}\text { Livestream, Ustream, Youknow, } \\
\text { Dacast }\end{array}$ \\
\hline 32) Ubicación/geolocalización & $\begin{array}{l}\text { Foursquare, GyPsii, Mapquest, } \\
\text { Google Maps }\end{array}$ \\
\hline 33) Viajes y hospitalidad & $\begin{array}{l}\text { Airbnb, VRBO, Onefinestay, } \\
\text { Couchsurfing }\end{array}$ \\
\hline
\end{tabular}




\begin{tabular}{|l|l|}
\hline $\begin{array}{l}\text { 34) Videollamadas y } \\
\text { videoconferencias }\end{array}$ & Skype, VoxOx, Line, Ekiga \\
\hline 35) Videos & $\begin{array}{l}\text { Daily Motion, Vimeo, Youtube, } \\
\text { Metacafe }\end{array}$ \\
\hline
\end{tabular}

Fuente: Elaborada a partir de Solis, B. y Thomas J. (2018). The conversation prism version 5.0. Recuperado de https://conversationprism.com/

Los diferentes canales y espacios presentados anteriormente, permiten de manera individual y colectiva, establecer conversaciones $e$ interacciones que ayudan a la construcción de capital social entre las organizaciones y los diferentes públicos con los que se vinculan. Algunos mensajes construirán relaciones personales entre los integrantes de grupos homogéneos (bonding social capital) o heterogéneos (bridging social capital) o con personas, organizaciones e instituciones que tienen un poder relativo sobre ellos (linking social capital).

Por lo tanto, los elementos privados del capital social generan vinculaciones a una estructura de relaciones -relaciones con otras personas- y a los recursos de dichas relaciones -apoyo a través de la red de relaciones- dentro de una categoría individual, mientras que los elementos públicos generan vinculaciones a los recursos colectivos estructurales -compromiso cívico-y a los recursos colectivos cognitivos-confianza, normas de cooperación, valores compartidos y reciprocidad-dentro de una categoría colectiva (ver tabla 5).

Tabla 5. Categorías del capital social.

\begin{tabular}{|c|c|c|}
\hline Capital social & $\begin{array}{c}\text { Estructura de red } \\
\text { y actividades }\end{array}$ & $\begin{array}{c}\text { Recursos/fuentes } \\
\text { productivas }\end{array}$ \\
\hline Individual & Relaciones personales & $\begin{array}{c}\text { Apoyo a través } \\
\text { de una red social }\end{array}$ \\
\hline Colectivo & Compromiso civil & $\begin{array}{c}\text { Confianza, normas } \\
\text { de cooperación, valores } \\
\text { compartidos y reciprocidad }\end{array}$ \\
\hline
\end{tabular}

Fuente: Elaborada a partir de Scrivens, K. y Smith, C. (2013).

Las organizaciones no están aisladas, por lo que su dimensión relacional está constituida por las conversaciones e interacciones que 
tienen lugar con las personas con las que se vinculan, y al estar dentro de ciertas estructuras sociales como redes, asociaciones e instituciones, comparten ciertas reglas y procedimientos en común, dando paso a la dimensión estructural del capital social, además de que dichas organizaciones pueden incluir información que permite construir representaciones de la realidad para elaborar conocimientos, actitudes y comportamientos a través de valores compartidos, además de reciprocidad, confianza, normas de cooperación y compromiso civil para constituir la parte cognitiva del capital social que puede diluirse y no estar presente a un nivel macro como en las organizaciones gubernamentales y en la gobernanza en general (Grootaert y van Bastelaer, 2001).

La dimensión estructural del capital social se refuerza mutuamente con la dimensión cognitiva y se hacen presentes a nivel macro en el ambiente político e institucional del gobierno así como en los acuerdos de gobernanza donde podemos encontrar relaciones verticales entre distintas organizaciones con el Estado, a nivel meso encontramos relaciones horizontales y verticales entre diversas organizaciones, grupos y/o asociaciones, mientras que a nivel micro, las relaciones son horizontales entre personas con otras personas o grupos (Grootaert y van Bastelaer, 2001) (ver tabla 6).

Tabla 6. Formas y alcance del capital social.

\begin{tabular}{|c|c|c|}
\hline \multirow[b]{2}{*}{ Estructural } & \multicolumn{2}{|c|}{ Macro } \\
\hline & $\begin{array}{l}\text { Instituciones del } \\
\text { Estado }\end{array}$ & Gobernanza \\
\hline & Leyes & \\
\hline & Instituciones locales & Meso \\
\hline & Redes & $\begin{array}{l}\text { Valores compartidos, } \\
\text { reciprocidad, } \\
\text { confianza, normas de } \\
\text { cooperación } \\
\text { compromiso civil }\end{array}$ \\
\hline
\end{tabular}

Fuente: Modificado de Grootaert, C. y van Bastelaer, T. (2001). 
Por lo tanto, dentro del contexto digital de la web 2.0 y 3.0, las organizaciones deben partir de ocho elementos importantes: ética/moral, impacto, presencia, proximidad, colaboración, participación, responsabilidad social organizacional y capital social (Rebeil Corella y Arévalo Martínez, 2017; Santos Morales y Arévalo Martínez, 2017), lo que permite establecer los siguientes principios para la comunicación digital.

1. Involucrarse de manera sólida con las personas para:

- Mantener una conversación e interacción respetando la dignidad infinita de la persona a través de valores compartidos por la organizacióncomo parte inicial de la dimensión relacional del capital social (ética y moral de la organización y de su comunicación).

- Crear valor en la comunicación, lo que permitirá continuar con la dimensión relacional del capital social entre la organización y las personas (impacto de la organización y de su comunicación).

- Desarrollar espacios para el intercambio de información valiosa como parte de la dimensión cognitiva del capital social (presencia de la organización).

- Establecer una continuidad en las conversaciones con las personas, lo que implica confianza para poder acercarsecomo parte de la dimensión relacional del capital social (proximidad de la organización).

2. Usar la web 1.0, 2.0 y 3.0 junto con una comunicación dinámica y productiva de carácter completamente bidireccional y/o multidireccional para:

- Generar redes de colaboración con el mayor alcance posible para el desarrollo socio-cultural de la comunidad donde la organización se desarrolla como parte de la dimensión estructural del capital social (colaboración con la organización). 
- Buscar una interacción comprometida de la organización enfocada al bien común como parte de la dimensión cognitiva del capital social (participación con la organización).

- Atender de manera comprometida los aspectos ecológicos, económicos, sociales, culturales y ecológicos que conlleva una responsabilidad social organizacional (responsabilidad social de la organización/RSO) como parte de la dimensión relacional, estructural y cognitiva.

- Generar estructuras de red y actividades mediante relaciones personales y un compromiso civil, así como recursos y fuentes productivas a través del apoyo en red, confianza, reciprocidad y normas de cooperación como parte de la dimensión relacional, estructural y cognitiva (capital social latente de la organización) (Rebeil Corella y Arévalo Martínez, 2017; Santos Morales y Arévalo Mártinez, 2017),

Sin embargo, cualquier organización que busque potencializar su capital social debe tomar en cuenta dentro de sus planes, programas, estrategias, tácticas, conversaciones e interacciones los siguientes tres ejes: las personas (people), las asociaciones (partnerships) y las políticas (policy) (Donovan y Henly, 2010; Weinreich, 2011). La relación que esos ejes tienen con los diferentes tipos de capital social se muestra en la tabla 6.

Tabla 7. Ejes y tipos de capital social.

\begin{tabular}{|l|c|}
\hline EJES DEL CAPITAL SOCIAL & CAPITAL SOCIAL \\
\hline $\begin{array}{l}\text { Personas } \\
\text { (People) }\end{array}$ & $\begin{array}{c}\text { Capital social de lazos fuertes (bonding } \\
\text { social capital) }\end{array}$ \\
\hline $\begin{array}{l}\text { Asociaciones } \\
\text { (Partnerships) }\end{array}$ & $\begin{array}{c}\text { Capital social de puente (bridging social } \\
\text { capital) }\end{array}$ \\
\hline $\begin{array}{l}\text { Políticas } \\
\text { (Policy) }\end{array}$ & $\begin{array}{c}\text { Capital social de vinculación } \\
\text { (linking social capital) }\end{array}$ \\
\hline
\end{tabular}

Fuente: elaboración propia.

De tal manera que una organización en Internet, al utilizar una o varias de las diversas categorías de conversación e interacción digital disponibles en la web 2.0 y 3.0, mediante una comunicación de pensamiento dinámico y/o productivo enfocada a las personas, puede 
generar un capital social de lazos fuertes y al buscar diversas asociaciones por ejemplo con celebridades, influencers, e incluso con otras organizaciones, puede generar un capital social de puente, todo esto, enmarcado en ciertas políticas de poder y autoridad que le darán orden y sentido a sus relaciones sociales, estableciendo así un capital social de vinculación (ver figura 1).

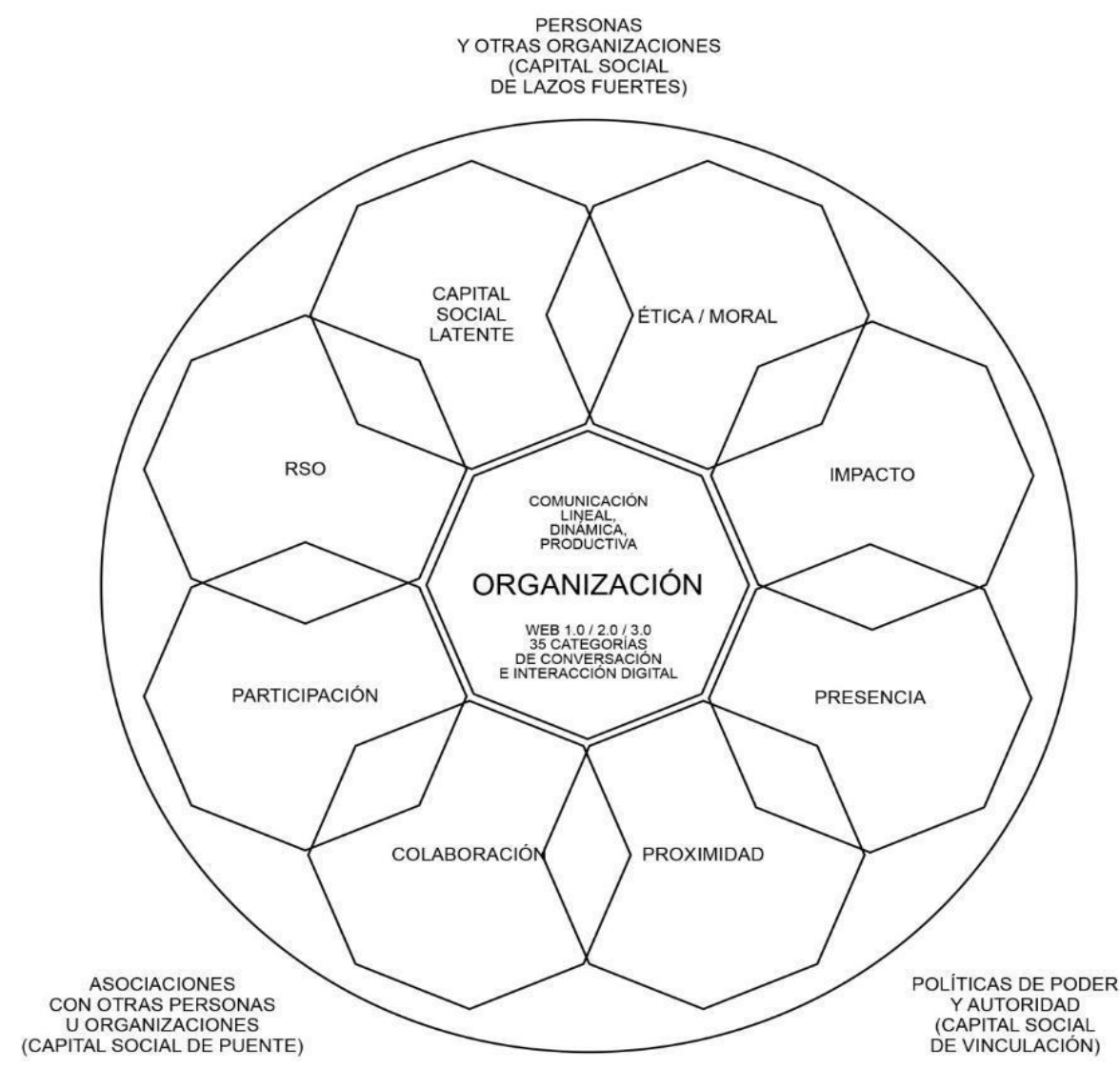

Figura 1. El capital social de las organizaciones en el contexto digital. Fuente: Modificado y ampliado de Santos Morales, R. y Arévalo Martínez, R. I. (2017).

\section{Conclusiones}

Cualquier organización posee un capital social latente que puede ser potencializado al establecer conversaciones e interacciones en los diversos canales y espacios digitales con los que actualmente cuenta Internet. Esto permite a una organización establecer relaciones personales, apoyo, compromiso cívico, valores compartidos, reciprocidad, confianza y normas de cooperación con grupos homogéneos y heterogéneos de personas a través de diferentes niveles de comunicación para construir diversos tipos de capital social. 
A lo largo de este texto, se han mostrado las posibilidades y recursos que tiene una organización en el contexto digital, los cuales, están acumulados en la web, listos para ser usados y ayudar a construir y coconstruir nuevas oportunidades de crecimiento y desarrollo, por lo que en pleno siglo XXI, basta un clic para que el capital social latente se convierta en un capital social manifiesto, capaz de provocar un cambio y una transformación social no sólo a nivel local, sino también a nivel planetario.

\section{Referencias}

Bourdieu, P. (1986). The forms of capital. En J.G. Richardson, Handbook for theory and research for the sociology of education (pp. 241258). Westport, CT: Greenwood.

Bourdieu, P. y Wacquant, L. (1992). An invitation to reflexive sociology. Chicago, IL: University of Chicago Press.

Coleman, J. (1988). Social capital in the creation of human capital. American Journal of Sociology, 94, S95-S120.

Coleman J. (1990). Foundations of social theory. Cambridge, MA: Belknap.

Donovan, R. y Henley, N. (2010). Principles and practice of social marketing. An international perspective. Cambridge, UK: Cambridge University Press.

Forni, P., Siles, M. y Barreiro (2004). ¿Qué es el capital social cómo analizarlo en contextos de exclusión social y pobreza? (Reporte de investigación \#35). East Lansing, MI: The Julian Samora Research Institute-Michigan State University.

Grootaert, C. y van Bastelaer, T. (2001). Understanding and measuring social capital: a multidisciplinary tool for practitioners. Washington, DC: World Bank Publications.

Hanifan L. (1920). The community center. Boston, MA: Silver Burnet. Howard, P. (2005). Sociedad on line. Internet en contexto. Barcelona: UOC. Huysman, M. (2004). Social capital and information technology. Cambridge, MA: MIT.

Katz J. (2005). Consecuencias sociales del uso de Internet. Barcelona: UOC. Küster, I. y Hernández, A. (2013). De la Web 2.0 a la Web 3.0: antecedentes y consecuencias de la actitud e intención de uso de 
las redes sociales en la web semántica. Universia Business Review, 37, 104-119.

Lin, N. (2001). Social capital. A theory of social structure and action. Cambridge, MA: Cambridge University Press.

Lin, N. (1999). Building a network theory of social capital. XIX International Sunbelt Social Network Conference, Charleston South Carolina, February 18-21.

López Novelo, R. (2011). La construcción del capital social en las redes sociales en Internet: Discutamos México en Facebook (Tesis doctoral inédita). UNAM, Ciudad de México.

Marx, C. (1985). El capital. Tomo I. México: FCE.

Nahapiet, J. y Goshal, S. (1988). Social capital, intelectual capital and the organizational advantage. Academy of Management Review, 23 (2), 242-266.

Nosnik, A. (2013). Teoría de la comunicación productiva. Exploraciones más allá de la retroalimentación. Rosario: Homo Sapiens.

Putnam, R. (1993). Making democracy work. Princeton, NJ: Princeton University Press.

Putnam, R. (2000). Bowling alone. The collapse and revival of american community. New York, NY: Simon and Schuster.

Rebeil Corella, M. A. y Arévalo Martínez, R. I. (2017). Presencia, interacción y responsabilidad organizacional en las redes sociales digitales de organizaciones privadas en Iberoamérica. En R. I. Arévalo Martínez y M. A. Rebeil Corella (coords.), Responsabilidad social en la comunicación digital organizacional (pp. 17-51). México: Tirant Lo Blanch.

Santos Morales, R. y Arévalo Martínez, R. I. (2017). Relaciones públicas, capital social y responsabilidad social: una perspectiva teórica para las organizaciones comerciales a partir de las campañas ganadoras del Festival Internacional de Creatividad Leones de Cannes 2017. En J. Herrero y M. Trenta (coords.), El fin de un modelo de politica (pp. 1635-1664). Tenerife: Universidad de La Laguna.

Scolari, C. A. (ed.) (2015). Ecología de los medios. Entornos, evoluciones e interpretaciones. Barcelona: Gedisa.

Scrivens, K. y Smith, C. (2013). Four interpretations of social capital. An agenda for measurement. OECD Statistics Working Papers, 2013/06, Paris: OECD Publishing. 
Shirky, C. (2008). Here comes everybody. The power of organizing without organizations. New York, NY: Penguin Books.

Solis, B. y Thomas J. (2018). The conversation prism version 5.0. Recuperado de https://conversationprism.com/

Weinreich, N. K. (2011). Hands-on social marketing. A step-by-step guide to designing change for good. Thousand Oaks, CA: Sage.

Wellman, B. y Haythornthwaite, C. (eds.) (2002). The Internet in everyday life. Malden, MA: Blackwell.

W3C (2012). Guía sobre web semántica. Recuperado de http://www.w3c.es/Guiasbreves/WebSemantic 



\title{
Recursos para la gestión de la comunicación online
}

\author{
Verónica Altamirano \\ Universidad Técnica Particular de Loja \\ Fabiana Altamirano \\ Universidade de Vigo
}

\begin{abstract}
PARA CITAR: Altamirano, V. y Altamirano, F. (2018). Recursos para la gestión de la comunicación online. En Túñez-López, M., Costa-Sánchez, C. y Valdiviezo, C. (Eds.), (2018). Comunicación Organizacional en entornos online. Gestión, actores y recursos. Cuadernos Artesanos de Comunicación, no 149 (pp. 75-106). La Laguna (Tenerife): Latina.
\end{abstract}

\section{Resumen}

La comunicación organizacional se encuentra en un proceso de transformación. Evoluciona de una comunicación de masas controlada, destinada a la promoción asimétrica y unidireccional a una nueva era de la información multimediática en la Red. Esta evolución se caracteriza por incorporar la participación global de los usuarios. Desde siempre, durante el proceso de decisión y compra de un producto o servicio, el cliente busca información y referencias de la oferta, pero, este proceso de comunicación, en la actualidad, está influenciado por una actitud colaborativa del usuario, que implica comunicación bidireccional e interactiva en planos de igualdad por ambas partes.

Palabras clave: gestión de la comunicación, comuncación bidireccional, comunicación interactiva. 
La comunicación organizacional se encuentra en un proceso de transformación. Evoluciona de una comunicación de masas controlada, destinada a la promoción asimétrica y unidireccional a una nueva era de la información multimediática en la Red. Esta evolución se caracteriza por incorporar la participación global de los usuarios. Desde siempre, durante el proceso de decisión y compra de un producto o servicio, el cliente busca información y referencias de la oferta, pero, este proceso de comunicación, en la actualidad, está influenciado por una actitud colaborativa del usuario, que implica comunicación bidireccional e interactiva en planos de igualdad por ambas partes.

En este escenario, los sitios web se consolidan como una plataforma indispensable para la promoción y la difusión de las organizaciones, pero los cambios en el comportamiento del usuario 2.0, exigen que estas plataformas se adapten a sus necesidades y ofrezcan recursos y herramientas que dinamicen la oferta junto a espacios de interactividad que permitan su participación y el establecimiento de una asesoría directa en la red. Estos sitios se complementan con la presencia de los social media, que contribuyen a generar espacios para la cocreación de contenidos y consecuentemente para la generación de una comunicación transmedia.

"Es un hecho que la democratización de la posibilidad de ser emisor de mensajes con potenciales públicos de masas como receptores y la universalización de la conexión interpersonal a través de Internet permite a los usuarios interactuar de uno a uno, o de uno a varios o, como mucho, en pequeños grupos, y relacionarnos todos con todos. Han variado, también, los flujos del mensaje, evolucionando de un modo unidireccional (discursivo) a una circulación realmente interactiva $y$, en simultáneo, en varios soportes. De este modo, la narración se construye y se modifica desde varios actores, desde múltiples emisores, a través de más de un canal y utilizando diferentes recursos multimedia" (Túñez y Altamirano, 2015). 
Es decir, la forma como se comunica la sociedad ha evolucionado a un modelo bidireccional, participativo, voluntario y comprometido, en el que el usuario es quien controla los procesos de comunicación.

"El hecho de que con Internet el "gran público", por primera vez en la historia, pueda cumplir con su clásica función viral "dentro del propio medio" -que es, por ende, el primer medio global-, introduce un cambio cualitativo en el potencial mediático de la conversación como canal de amplificación informal (horizontal, igualitario) de mensajes intencionales lanzados por emisores ávidos de viralidad y capaces de planificar y ejecutar sofisticadas estrategias comunicativas vía user-generated content" (Carrera, 2011:39).

Por tanto, es necesario que la comunicación organizacional se adapte a estos cambios y migre de la comunicación tradicional a la digital y 2.0, creando plataformas de comunicación en las cuales el usuario 2.0 tenga acceso, no solo, a la información, sino que cuente con espacios en los que pueda participar e interactuar.

La influencia de Internet en la sociedad a partir de su descubrimiento es evidente. Ha contribuido a la consolidación de la "sociedad de la información", de la "sociedad del conocimiento" y "la sociedad red". La sociedad Internet se sitúa en el núcleo de la nueva era de la comunicación organizacional, optimizando las posibilidades de comercialización directa de productos y/o servicios, evitando, por tanto, una obsoleta trama de intermediarios. En efecto, el impacto causado por la aparición de importantes plataformas digitales, a partir de las cuales se puede gestionar la comunicación organizacional en todos sus ámbitos, ha situado en una nueva coyuntura a las políticas de comunicación de las organizaciones (De San Eugenio Vela, 2012).

Internet representa un cambio cualitativo de la "comunicación de masas" se pasa ahora al que podemos denominar "Personalización en masa", es decir, la posibilidad de facilitar la información personalizada -en contenido, pero también en tiempo y lugar de consumo- a un número masivo de personas. Internet, como en general la comunicación, no se puede analizar únicamente desde la perspectiva 
de la difusión o del acceso a la información, sino que también debe analizarse desde el punto de vista de su incidencia en la organización social, en la comunidad. Sin poder afirmar que hayan desaparecido las formas de cohesión masiva o de homogeneización de la opinión pública, también es cierto que las nuevas redes sociales aceleran los movimientos ciudadanos alternativos... En este sentido, Internet no excluye la influencia de los medios, pero determina cambios sociales importantes y crea nuevos espacios y nuevas formas de comunidad en el ciberespacio (De Moragas, 2012: 9).

En este escenario, la sociedad está cada vez más "conectada", el acceso a la información y al conocimiento es mayor, las empresas, organizaciones y negocios han migrado a la Red incrementando el comercio electrónico. Este entorno digital es dominado y contralado por los usuarios desde los computadores o dispositivos móviles, adquiriendo mayor importancia y presencia de Internet.

El portal Internet World Stats, es un sitio web que proporciona datos estadísticos actualizados referentes al acceso a Internet. De acuerdo al último informe de diciembre del 2017 la penetración del internet a nivel mundial alcanza un 54,4\%, con un total de 4.156.932.140 personas conectadas a la Red. De esta manera, Internet se ha convertido en la principal fuente de consulta para los usuarios y consecuentemente en una de las herramientas más importantes para la comunicación organizacional, de esta manera, las organizaciones han implementado diversas plataformas para relacionarse -no solo comunicarse- con sus públicos objetivos.

\section{Sitios web interactivos}

La concepción del término sitio web es en algunos casos ambigua o desde el punto de vista de los usuarios - se lo utiliza como sinónimo de página web por la estrecha relación que tienen. García (2001: 6) define a un sitio web como un conjunto de páginas estructuradas sobre la base de una organización de contenidos rigurosos y que éstas se componen de una o más páginas, pero sin que necesariamente esté implícita la idea de estructuración de información con criterios rigurosos. Es decir, deben ser accesibles, intuitivas para que permitan navegar fácilmente y 
que se adapten a los criterios y necesidades de los usuarios, que sea posible personalizarlas.

Kozak y Baloglu (2011) sostienen que una página web debe ser interactiva, estimulante y atractiva para involucrar a los visitantes potenciales en las comunicaciones interactivas y proporcionar una experiencia... debe incluir diferentes enlaces para múltiples grupos de interés y ser personalizado a múltiples segmentos de visitantes. El contenido se puede adaptar a las diferentes audiencias a través de secciones múltiples y ajustes personalizables para crear una imagen favorable.

La convergencia hacia lo digital en la comunicación organizacional permite que el usuario acceda de manera directa a la oferta e incluso realizar compras online. Pero, frente a la excesiva información que se encuentra en Internet, se requiere que las organizaciones complementen con un valor agregado la promoción y difusión en la web, para lo cual se debe incluir contenidos y herramientas de calidad en sus plataformas de promoción digital. En la actualidad, no solo los aspectos técnicos son importantes en el desarrollo de un sitio web, como lo menciona Palazón Meseguer (2001):

"La mejor propuesta de cualquier sitio web para fidelizar a un usuario es que ofrezca unos contenidos de calidad... disponer de un contenido diferenciador distingue a los sitios web. Esto produce una necesidad que hace que el usuario vuelva a la web de forma habitual. Y de forma clara, el contenido diferenciador ofrece toda una serie de mecanismos (foros, tablón de anuncios, chat, correo electrónico...) para establecer una relación con el usuario" (p. 93).

Marcos y Codina (2005), resumen las características que deben cumplir las páginas web:

- Fácil localización, ya sea a través de un buscador o directamente.

- Velocidad. Que la página opere con rapidez.

- Usabilidad. Hacer el sitio atractivo, fácil de utilizar y coherente gráficamente, para que mantenga el interés del usuario. 
- Contenido. Suministrar informaciones de calidad, interesantes para el usuario, de forma correcta, actualizada, creativa y amena.

- Interactividad. Proporcionar al usuario la posibilidad de buscar la información que requiera, facilitar las reservas, los enlaces, la ayuda y la atención al cliente.

Fernández-Cavia et al. (2013), recabando algunas aportaciones recientes sobre el tema proponen una serie de recomendaciones que sirven como claves de éxito para obtener una página web "ganadora" (winning website), es decir, una web efectiva y de calidad:

"Plantear la accesibilidad como base de la calidad de la página web, pues es un derecho del cliente y un bien para la organización. El contenido de la web debe ser bien percibido y entendible por el usuario, la interconexión de elementos debe ser operativa y el contenido debe ser suficientemente sólido para trabajar con el presente y el futuro de las nuevas tecnologías".

Seguir pautas basadas en la investigación para crear una web de fácil usabilidad que construya identidad y confianza, o bien optimizar la página web actual usando pautas pre-establecidas. La clave es ofrecer información con la máxima confianza posible. Aplicaciones como About us, Contact us, Privacy Policy and Terms of the Site ayudan a transmitir seguridad en el sitio web. Asimismo, se debe pensar en las palabras clave para unos buenos resultados en el posicionamiento natural de los buscadores, Search Engine Optimization (SEO) como Yahoo o Google.

El desarrollo de las nuevas tecnologías ha propiciado que los portales web de las organizaciones sean ya considerados como tarjetas de presentación que por sí solas comunican y como potentes herramientas de acceso hacia y para los usuarios, de manera que resulta conveniente e imprescindible que tanto la imagen, como la información y actividades de empresas y organismos públicos, quede reflejada en sus portales web; se trata, en suma, de una herramienta de comunicación que ha de ser coherente con los objetivos institucionales, que ha de contribuir a la transmisión de información (Fernández Poyatos, Aguirregoitia Martínez y Boix Martínez, 2011). 
Es necesario que la promoción que se realice a partir de los sitios web se complemente con la creación de cuentas en las principales redes generalistas, para fomentar una comunicación interactiva en la que se consiga la participación voluntaria del usuario como generador de contenidos y promotor de los productos o servicios que ofrece la organización.

Los sitios web deben promover la comunicación 2.0, generando contenidos de calidad y multimediáticos para que sean compartidos y viralizados por los usuarios 2.0, ofreciendo herramientas digitales que mejoren la experiencia del cliente. También, deben incluir espacios de asesoría y comunicación en línea y crear las plataformas digitales colaborativas en las cuales los viajeros puedan compartir información, referencias, experiencias.

La promoción digital debe mantener coherencia con la imagen de la empresa, siendo necesario que los contenidos se adapten al formato de cada plataforma en la que se promocionan. Así como los medios de comunicación tradicionales tienen su propio formato, los digitales también requieren de una planificación estratégica específica y que los contenidos sean adecuados para cada uno, utilizando recursos multimedia que potencien la comunicación con el usuario.

El nuevo entorno digital ha cambiado la forma de transmitir y recibir la información. El usuario es quien controla, domina, maneja y conecta los contenidos de una forma no lineal creando las denominadas obras abiertas a través de la participación y la interacción. Esta narración digital es posible gracias al hipertexto, a los recursos de multimedia e hipermedia que promueven la creación de narrativas transmedia y crossmedia.

Estas narrativas (multimedia, transmedia y crossmedia) involucran al usuario 2.0 en el proceso de construcción del mensaje componiendo experiencias lo que fortalece la relación con la marca y la promoción y difusión de los productos y servicios permitiendo, de cierto modo, tangibilizar la oferta para hacerla visible y real hacia el usuario. 
Otro aspecto que se debe tener como referencia al diseñar un sitio web es la interactividad. Las principales características del usuario 2.0 son la voluntad y el compromiso para interactuar en los entornos digitales. Por lo tanto, las plataformas corporativas deben brindar las condiciones necesarias para que se establezca una relación entre el usuario y la organización. También, deben publicar contenido de calidad que motive al cliente a compartir la información en sus redes personales, hasta convertirlo en un promotor de la marca y que genere viralidad en la Red, lo que beneficiará a la difusión de los mensajes promocionales.

Para contrarrestar la avalancha de información que existe en Internet las empresas y organizaciones deben constituirse como la principal fuente de información del usuario. En los sitios web se deben incluir las herramientas y los espacios para que los usuarios reciban información directa y precisa desde la organización, ya sea a través de chats, solicitudes automáticas de información, servicios de atención en línea, videoconferencias o los datos de contacto de las oficinas de atención al cliente. Esto, con la finalidad de brindar una atención inmediata y oportuna.

En los sitios web también se debe potenciar la creación de comunidades virtuales en las que el usuario pueda compartir sus inquietudes y experiencias, lo que permitirá fortalecer la imagen de la organización. Desde siempre la referencia de otros clientes ha influido en la toma de decisiones, pero en la actualidad, el espacio digital adquiere relevancia. Como lo afirma Di Placido (2010: 7):

Mirando este nuevo escenario comunicativo desde una perspectiva comercial, podemos constatar como la interacción C2C - Consumer to Consumer - (Huang, Hsu, 2009) está teniendo un fuerte impacto sobre el entero proceso decisional... El tradicional proceso comunicativo/informativo definido boca a boca se está transformando por efecto de los medios que operan en una lógica 2.0 en una tipología de boca a boca electrónico también definido e- Word of Mouth (Latvin, Golsmith, Pan, 2006), un proceso donde asume una relevante importancia el fenómeno de la influencia interpersonal online. 
Las comunidades virtuales son una realidad. "Internet se está usando para practicar estrategias de marketing relacional y crear comunidades virtuales en torno a una marca o un producto en las que se busca la participación del visitante en el proceso de comunicación. Constituyen un verdadero punto de encuentro donde los usuarios con expectativas comunes comparten información sobre los productos que les interesan" (Túñez, Sixto y Guevara, 2011, p. 53 - 65). Por tanto, las empresas deben promover la creación de estas comunidades en torno a su marca, con la finalidad de obtener información directa de la fuente y para controlar lo que se dice respecto a su producto, lo que permitirá realizar mejoras y adaptar la oferta a las necesidades del mercado. En este sentido, los portales web también deben incluir herramientas interactivas como foros o encuestas y permitir la participación del usuario generando comentarios, información y compartiendo contenidos, entre otros.

La presencia de las organizaciones en los diferentes medios sociales es fundamental. Las redes generalistas, como Facebook, Google+ y Twitter permiten acercarse al público objetivo de una manera amigable y consiguen transmitir el mensaje, pero, principalmente, generar viralidad. Mientras que las redes para compartir vídeo e imágenes, como YouTube, Pinterest, Flickr e Instagram, se convierten en un repositorio de material promocional a la vez que divulgan las campañas publicitarias.

Es preciso recalcar que en este mundo globalizado no basta con crear las herramientas interactivas o tener presencia en los diversos medios sociales. Las organizaciones deben adquirir un compromiso 2.0. Producir contenido de calidad adaptado para cada plataforma, actualizar la información y atender de manera permanente e inmediata al usuario. Como recalcan Túñez y Sixto (2011), para "la participación en los entornos 2.0 no basta con la presencia, sino que se exige también la contribución activa tanto de los creadores como de los usuarios, intercambio opiniones y contenido, de manera que ambos obtengan beneficios, en plena sintonía con el concepto de marketing" 


\subsection{Formatos interactivos en los sitios web}

Las organizaciones "deben trabajar en crear espacios interactivos que permitan la conformación de comunidades para que los usuarios de manera voluntaria y en co-creación sean quienes promocionen" su marca (Túñez, Altamirano y Valarezo, 2016). Los formatos interactivos son aquellos que permitan el dialogo y la interactividad en la comunicación digital y que son utilizados exitosamente en la comunicación 2.0. Orihuela (2010: 323) sostiene:

"El correo electrónico, los grupos de noticias, los foros, la mensajería, los blogs, las redes sociales y los microblogs han ido redibujando y extendiendo los alcances de la noción de interactividad. En su conjunto, todas estas prácticas han transformado el modo en el que la gente entiende y practica la comunicación, hasta tal punto que hoy ya resulta incomprensible e inaceptable cualquier modelo de comunicación que no incorpore de un modo efectivo, y no puramente nominal, a los usuarios y a su discurso".

Es preciso recalcar que, además, del aporte para establecer una relación interactiva entre el usuario 2.0 y la organización los formatos interactivos generan tráfico a los sitios web lo que permite mejorar el posicionamiento en buscadores. Entre los formatos interactivos se destacan:

- Correo electrónico. Se constituye como una de las primeras herramientas que permitió que los usuarios interactúen y se comunique prácticamente en tiempo real; librando las limitaciones de la distancia. "Consiste en una manera rápida de comunicarse mediante ordenadores, frente a la necesidad de remitir documentos y textos de consulta, además permite transportar elementos electrónicos mediante copias y estas pueden contener elementos visuales y sonoros" (Castillo, 2004, p. 238). En el ámbito de la comunicación organizacional, el correo electrónico, cumple dos funciones principales: como un canal de comunicación bidireccional e interactivo entre el usuario 2.0 y la organización y como una herramienta para la 
implementación de estrategias e email marketing. El correo electrónico, como una herramienta de gestión que promueve la comunicación interactiva, permite:

- Personalizar el mensaje para mantener una comunicación directa y bidireccional con los stakeholders.

- Remplaza al correo tradicional por lo tanto es un canal más económico.

- La distribución a varios receptores simultáneamente, y que estos a su vez lo reenvíen a sus contactos (viralidad)

- Genera una comunicación interna multidireccional (ascendente, descendente y horizontal).

- Para los clientes constituye una fuente importante de consulta debido a la inmediatez de respuesta.

Además, se consolida como un canal de comunicación directo (Kotler, Gertner, Rein, y Haide, 2007): "El correo electrónico tiene la capacidad de llegar a un mercado meta enormemente enfocado. El mensaje puede ser estándar o completamente adaptado a cada receptor. El correo directo sirve para describir una oferta, hacer un recordatorio, realizar una sugerencia o responder a una solicitud"

- Foros de discusión. Se conforma por grupos de personas que se reúnen voluntariamente de manera electrónica para tratar temas de internes común, estableciendo la colaboración activa y dinámica del participante que puede intercambiar comentarios, opiniones, ideas, mensajes y decidir en línea.

María Gabino (2004: 123) afirma que los foros de discusión: funcionan como buzones de correo públicos donde los usuarios leen y envían mensajes relacionados con un tema común. Los usuarios suelen ser personas con conocimientos previos $\mathrm{O}$ intereses en el tema del foro al cual se han suscrito. Concreta la explicación con el aporte de Jones, el cual describe el foro como un tablón de anuncios en donde se ponen mensajes con noticias, peticiones y respuestas de información sobre el tema en particular del cual trate dicho foro 
En los sitios web organizacionales la implementación de foros de discusión permite crear comunidades en las cuales participan voluntariamente los usuarios 2.0. Estos foros, brindan diversos beneficios para la comunicación:

- Generar una comunicación bidireccional y directa con el público objetivo.

- Entregar información de manera directa a los interesados, pero hacerlo en un ambiente social y amigable a través de una comunicación horizontal.

- Recolectar información referente a las experiencias del usuario 2.0, de sus necesidades y expectativas para mejorar la oferta.

- Identificar a los influenciadores o líderes de opinión para establecer una relación directa y conseguir convertirlos en promotores de la marca.

- Generar viralidad con la participación de los miembros de la comunidad.

- Mensajería instantánea - chat. Derivado del término inglés "chat" que significa charla o conversación, esta herramienta permite iniciar un diálogo directo y simultaneo entre personas que no se encuentran cerca físicamente. En su origen solo era posible un dialogo textual, en la actualidad se ampliaron sus funciones y permiten el intercambio de archivos, imágenes, vídeo y la posibilidad de realizar llamadas o videoconferencias.

La mensajería instantánea que inició con el MSN y ha evolucionado al formato móvil, con lo cual se ha expandido en el mercado. Las aplicaciones más utilizadas son WhatsApp con 1 billón de usuarios, QQ con 832 millones y Facebook Menssenger de usuarios a nivel mundial (Höhr, 2015).

Estas herramientas interactivas son de suma importancia para la atención al cliente; permite la conversación directa en tiempo real, y solucionar problemas de forma inmediata además de compartir información y archivos. En el ámbito corporativo deberían implementarse para brindar una atención personalizada al cliente. 
- Encuestas y entrevistas online. Constituyen una técnica para la recolección de información sumamente importante. El usuario participa de forma voluntaria, entregando datos relevantes sobre sus necesidades y expectativas, la experiencia con la marca, valora los diferentes productos o servicios y comparte su nivel de satisfacción mientras visita el sitio.

La encuesta online permite recolectar información específica de interés para la organización a través de un cuestionario que contiene una serie de preguntas previamente elaboradas, en base a los objetivos de la investigación. La encuesta se la puede colocar en un lugar visible de la página o sitio web de la organización y el usuario accede de manera voluntaria, también puede ser distribuida por correo electrónico a una base datos de un grupo objetivo específico.

La entrevista directa $\mathrm{u}$ online permite interactuar de manera simultánea a un miembro de la organización, que debe tener representatividad, con su público objetivo. Puede ser a través de chat o videoconferencia. El objetivo es el intercambio de información, esta es la oportunidad para obtenerla directamente de la fuente y conseguir acercarse al grupo objetivo para difundir mensajes seleccionados.

\subsection{Medios sociales}

Gracias a la búsqueda constante de información y la necesidad de compartirla por parte de los usuarios surgen diversas comunidades virtuales que se convierten en referente a la hora de seleccionar un producto o destino turístico. Estas comunidades se crean de manera voluntaria y en la mayoría de los casos de forma independiente a las empresas. Lo cual influye en la manera como las organizaciones se comunican con sus públicos, incorporando a la Internet y a los Medios Sociales en los planes y estrategias de comunicación. Sin embargo, la clave del éxito de la comunicación digital no es tener presencia en este entorno digital, ni generar información, sino "en la búsqueda de modos 
de gestionarla y hacerla atractiva para los usuarios" (Domínguez y Araujo, 2012: 226).

La tendencia de la sociedad a relacionarse a través de comunidades redes - con personas que comparten intereses similares es la base para la conformación de los medios sociales. Castells (2005: 403) manifiesta que "los nuevos medios de comunicación electrónicos no se alejan de las culturas tradicionales, sino que las absorben", a lo que añade Scolari (2012: 338):

"La aparición de nuevas formas interactivas y colaborativas de comunicación implicó grandes cambios en el ecosistema de medios. Las nuevas especies mediáticas modificaron las relaciones de un ecosistema donde los medios masivos denominados broadcasting por entonces- llevaban la voz cantante. Las nuevas formas de comunicación eran grandes depredadoras de la atención: si antes los consumidores dedicaban mucho tiempo a un puñado de medios (prensa, radio, televisión) en pocos años comenzaron a dedicar poco tiempo a muchos medios (webs, redes sociales, videojuegos, blogs, dispositivos móviles, etc.). Los grandes medios de difusión lucharon denodadamente por adaptarse a las nuevas reglas del juego y sobrevivir en un entorno cada vez más hostil. Algunos medios consiguieron subsistir mientras que otros, a pesar de los esfuerzos por adaptarse, se extinguieron".

De esta manera, los medios sociales permiten la creación de comunidades digitales en las que se establecen relaciones entre individuos con intereses afines. Estas comunidades virtuales son una realidad. "Internet se está usando para practicar estrategias de marketing relacional y crear comunidades virtuales en torno a una marca o un producto en las que se busca la participación del visitante en el proceso de comunicación. Constituyen un verdadero punto de encuentro donde los usuarios con expectativas comunes comparten información sobre los productos que les interesan" (Túñez, Sixto y Guevara, 2011: 53-65). Por lo tanto, las empresas deben promover la creación de estas comunidades en torno a su producto con la finalidad de obtener información directa de la fuente y para controlar lo que se 
dice respecto a su producto, lo que permitirá realizar mejoras y adaptar la oferta a las necesidades del mercado.

"Los medios sociales son plataformas digitales de comunicación que dan el poder al usuario para generar contenidos y compartir información a través de perfiles privados o públicos" (Interactive Advertising Bureau, 2009: 6). Lo que le otorga el poder al usuario para controlar los entornos en los que se desenvuelve.

Debido al impacto y penetración que tienen los medios sociales se han convertido en importantes herramientas de comunicación organizacional. Pero, son los usuarios quienes establecen las reglas y deciden qué actividad realizar, que ver, que marca seguir y como comunicarse. En este escenario, es la sociedad la que establece las pautas de comportamiento en las comunidades virtuales y por tanto las empresas deben adaptarse a este nuevo mercado. El usuario 2.0 exige una actitud 2.0 (actualización, participación e interacción) y compromiso, por tanto, si las organizaciones desean ingresar al entorno deben establecer una comunicación estratégica, dinámica, creativa e interactiva. "No cabe duda que, sin compromiso, sin estrategia, sin target y sin humanizar la marca no hay gestión efectiva del social media" (Ayestarán, Rangel y Ana, 2012: 238).

Algunas características de estos medios sociales, como herramientas de comunicación organizacional, son (Ramos Ostio, 2012: 77):

- Audiencia global

- Acceso fácil y económico

- Facilidad de uso

- Actualización instantánea

- Elaboración colectiva de contenidos

La aceptación que los usuarios han brindado a las marcas en los medios sociales es evidente. En el 2014, se incrementa el engagement de los usuarios con la marca y los contenidos publicados en Facebook (76\%), Twitter (109\%) e Instagram (131\%), es decir durante el año se registraron 42 billones de interacciones en las diversas redes (Shareablee, 2015). 
La presencia de las organizaciones en los diferentes medios sociales es fundamental. Las redes generalistas, como Facebook, Google+ y Twitter permiten acercarse al público objetivo de una manera amigable y consiguen transmitir el mensaje, pero, principalmente generar viralidad. Mientras que las redes para compartir video e imágenes, como YouTube, Pinterest, Flickr e Instagram, se convierten en un repositorio de material promocional turístico a la vez que divulgan las campañas publicitarias. A continuación, se describen los medios sociales generalistas que pueden ser utilizados en la comunicación organizacional.

\subsubsection{Blogs}

Con la aparición de la web 2.0 llegan los blogs. Páginas web que contienen anotaciones o historias (post) dotadas cada una de su propia dirección URL que suelen aparecer ordenadas en orden cronológico inverso (las últimas aparecen en primer lugar) y admiten ser ordenadas por categorías y que vayan acompañadas por comentarios hechos por los lectores de la página. También, suelen caracterizarse por la actualización frecuente y el empleo de un estilo informal en la escritura (Macias, 2007, p. 2). A este concepto se lo sintetiza como "el reflejo de una opinión personal en un formato multimedia, intercambio de información entre sujetos, capacidad socializadora del espacio compartido y facilidad de uso de la herramienta, entre otras cualidades" (García y Núñez, 2009: 245).

Los blogs marcan nuevos caminos en la comunicación organizacional; permiten relacionarse directamente con el público de una manera informal y difundir contenidos relevantes para la institución. Al igual que otros formatos interactivos demuestran transparencia en las acciones de la organización y el interés de acercamiento a sus stakeholders. Por lo que han ganado aceptación como medio publicitario entre los usuarios. El estudio realizado por Social Media y GFK31 (citado en Liberos et.al. 2014: 775) señala que:

El $82,4 \%$ de los usuarios de blogs afirman que una marca que se anuncia en blogs es una marca que conoce bien donde encontrar su target. Un 78,6\% defiende que las marcas más importantes en cada 
categoría deberían publicitarse en estos sitios especializados y para un 69,7\% las marcas más innovadoras están en este tipo de sitio. En general, la publicidad en blogs se considera más relacionada con la temática, más fiable y más novedosa en cuanto al uso de formatos.

Otro aspecto interesante para la comunicación que destaca el informe es que el 54,8\% de los comentarios que un usuario deja en un blog, más de un cuarto están dedicados a hablar de productos y marcas.

Entre las ventajas de un blog corporativo Ayestarán, Rangel y Ana (2012: 212) citan:

- Permite a las marcas emitir publicidad, se tiene control a través del SEM (pago por publicidad) sobre el mensaje publicitario. Con lo que no se puede considerar una práctica intrusiva.

- Los blogs son fáciles de posicionar en SEO, ya que proporcionan una gran visibilidad de la empresa como escaparate de la web corporativa o principal, redirigiéndose el tráfico a través de los enlaces da calidad que un usuario comparte en sus redes sociales.

\subsubsection{Microblogging}

Los canales de microcomunicación revolucionaron la comunicación personal y de la organización, a través del envío de mensajes con una longitud de 140 caracteres de forma instantánea y gratuita. La red más representativa del microblogging es Twitter.

Twitter es una plataforma de publicación web gratuita, muy sencilla, ligada a la cultura de los móviles y de los mensajes de texto. Su dimensión de red social en línea confiere a los mensajes el potencial de la viralidad instantánea y su carácter global le convierte en una extraordinaria herramienta de monitorización de información, fuentes y tendencias (Orihuela, 2010). Se revela como herramienta inmediata para el lanzamiento de información de venta y ofertas que precisa de una estrategia para llegar con claridad al consumidor: el uso adecuado del hashtags pero sobretodo entender el protocolo de búsqueda de información por parte del cliente son pasos fundamentales para la elaboración de la oferta (Martínez Villa, 2012: 98): 
"Twitter puede ser definido como un microblogging conversacional y, además de millones de personas, muchas empresas, organizaciones, medios de comunicación, ONGs o gobiernos lo utilizan para fines de comunicación tales como: marketing, atención al cliente, noticias, o incluso, activismo. Dadas sus propiedades aparentemente simples e inherentemente flexibles, en particular la brevedad y la velocidad" (Del-Fresno-García, 2014: 248).

El Twitter es, probablemente, una de las redes sociales más influyentes en el ámbito comercial debido a la cantidad de mensajes y conversaciones que se producen entorno a las marcas, lo que interviene en la creación de la imagen de marca y las decisiones de compra. Desde otro ángulo es, también, una importante herramienta para recolectar las opiniones de los usuarios por la facilidad de monitoreo que brinda, permitiendo dar una atención personalizada e inmediata y generando una experiencia agradable con los clientes, que valoran la respuesta de las organizaciones, pero, sobre todo la inmediatez. "Los sitios de microblogging proporcionan una plataforma para conectar directamente, casi en tiempo real, con los clientes, lo que puede construir y mejorar las relaciones con clientes" (Jansen, Zhang, Sobel, y Chowdury, 2009: 2186).

Esta nueva forma de comunicación revolucionó al mundo y su influencia depende de la calidad de los contenidos que se generan, no se trata de conseguir seguidores simplemente, sino de brindar una información relevante para que se mantengan en la Red.

Contestando a la pregunta ¿Qué haces? se posiciona como el líder mundial. Socialbakers (2018) sostiene que existen 313 millones de cuentas creadas en el mundo, de los cuales el 80\% accede desde el celular y se publican un promedio de 500 millones de tweets por día.

Guerrero-Solé y Fernández-Cavia (2013: 234) proponen las siguientes sugerencias para mejorar el crecimiento en Twitter:

- Encontrar un equilibrio entre las publicaciones y los retweets, se necesita encontrar un equilibrio entre la publicación de su 
información en la cuenta y la información de otras fuentes que pueden estar relacionados con sus objetivos.

- Teniendo en cuenta la influencia de los retweets y que el impacto es mayor que la influencia de la actividad, se debe encontrar estrategias para fomentar la retweeting y la difusión de sus mensajes.

- Promover acuerdos formales y no formales con otros usuarios. En este sentido, se debería promover su relación con otras cuentas de Twitter que puede retwittear sus mensajes y, en consecuencia, hacer que su visibilidad e influencia aumente en la red.

- Promover conversaciones y la mención de su cuenta. Las menciones tienen influencia en el impacto y la visibilidad. En consecuencia, se necesita aumentar las menciones en las cuentas que, al mismo tiempo, puede tener un impacto positivo en el número de seguidores.

- Tener información sobre los usuarios que retwetean los mensajes de sus cuentas. Se necesitan saber qué información se retwetea, así como la actividad y el número de seguidores de estos usuarios. Teniendo en cuenta la naturaleza viral de la difusión de información en la Red, esto es un punto crítico si quieren mejorar su impacto.

- Difundir información de otros. Que permitan establecer alianzas estratégicas que trasciendan más allá de las fronteras geográficas.

\subsubsection{Wikis}

Consideradas como una de las principales herramientas para la gestión del conocimiento, es un sitio web que permite que los artículos publicados sean leídos y editados por los usuarios en cualquier momento, generando un conocimiento colectivo en un entorno colaborativo.

Al utilizar la herramienta en el entorno empresarial permite que los trabajadores gestionen el conocimiento desde su área específica aportando al desarrollo de un archivo histórico, pero, sobre todo, presentando propuestas innovadoras o emprendedoras que pueden ser perfeccionadas por otros miembros de la organización.

\subsubsection{Redes para compartir fotografías y vídeos}

Teniendo en cuenta que actualmente nos dirigimos a un mundo audiovisual, estas plataformas de intercambio ofrecen a sus usuarios la 
posibilidad de almacenar, etiquetar y compartir fotografías o vídeos, permitiendo establecer la presencia de las organizaciones en los entornos digitales.

La importancia de la fotografía en la publicidad desde siempre ha sido un tema de estudio, por tanto, la fotografía se analiza desde la perspectiva de constituirse en un elemento clave en la promoción y, principalmente, su influencia en la percepción y construcción de la imagen de una marca. Sin embargo, gracias a la presencia de las redes para compartir fotografías, se debe establecer dos parámetros de estudio, el primero la publicitaria producida por las organizaciones y empresas con la intención de influir en la decisión del usuario y el segundo las fotos realizadas por los usuarios, más naturales que cuentan una historia y que transmiten una experiencia.

De esta manera, la fotografía, tanto la analógica nacida hace casi dos siglos como la actual fotografía digital, junto con las ilustraciones e imágenes virtuales generadas por ordenador ocupan un lugar de honor en la comunicación por Internet (Visa Barbosa, 2013: 96). Principalmente, la fotografía publicada por los usuarios en los medios sociales como referencia de la experiencia frente a una marca que adquiere mayor repercusión e impacto. Porque comparten sus vivencias (positivas o negativas) acompañadas de comentarios, pero respaldadas con las imágenes que pretende transmitir la experiencia vivida, generando un relato que configura una imagen en la mente de otros usuarios.

Maurer y Hinterdorfe (2013: 216-217) sostienen que las imágenes a menudo desencadenan las emociones y despiertan la atención de las personas sin usar palabras. Todo el que es capaz de ver puede percibir imágenes fácilmente. Por otra parte, casi todo el mundo que posee una cámara, un teléfono móvil y/o una computadora que puede tomar fotografías, editarlas y publicarlos en línea, lo que demuestra la facilidad de la producción de la imagen y, también, implica un movimiento hacia una cultura basada en imágenes.

Flickr. Reconocida mundialmente como la web de referencia para almacenar fotografías, se convirtió en un gran repositorio fotográfico 
que almacena la memoria en imágenes del mundo. "Incluye fotografías de diferentes usuarios que son de diferentes lugares y comparten sus fotos tomadas en diferentes partes del mundo. El acceso a este sitio está abierto para que cualquiera pueda ver fotos" (Koerbitz y Önder, 2013), lo que repercute en el impacto y viralidad que mantiene la Red. Esta herramienta permite a las empresas medir el nivel de popularidad de sus productos y marcas y conocer como son etiquetados por los clientes [...] esta web social nos aporta una gran cantidad de información sobre que mensajes han calado, cuáles son utilizados por los usuarios y cuáles no, como clasifican los productos, bajo que etiquetas, etc. En otras palabras, de Buisness Inteligence no sólo gratuita, sino con información real del mercado. (Celaya: 2009: 245)

Pinterest. El posicionamiento que busca la red social de imágenes es convertirse en un tablero virtual en el que los usuarios comparten las cosas bellas. Con esta idea sugerente ha conseguido 100 millones de usuarios activos en 5 años desde su fundación (Revista La Vanguardia, 2015) y que sus seguidores compartan 50 millones de pines, según lo anuncia en su página de inicio Pinterest (2016). "El creativo nombre de Pinterest surge de la unión de dos conceptos: el verbo inglés to Pin y el sustantivo Interest. Que, yuxtapuestos y traducidos, sería algo parecido al concepto de "colgar intereses". La primera definición oficial de Pinterest publicada en su website, lo definía como un "tablero virtual para organizar y compartir todas aquellas cosas bellas de la web". Actualmente, la definición se ha simplificado y Pinterest se define a sí mismo como una herramienta para coleccionar y organizar "las cosas que gusta" (González Macías, 2013).

Pinterest se aprovecha de la importancia y el poder de las imágenes, es una plataforma para compartir fotos en línea que permite a los usuarios recopilar, organizar y compartir imágenes de diferentes sitios web (Maurer y Hinterdorfer, 2013: 216-217). Lo que favorece a las organizaciones para crear la imagen corporativa construyendo tableros en función de las fotografías compartidas por los usuarios, es decir, difundiendo las referencias de los clientes que comparten sus experiencias. «La forma en que organizamos nuestros intereses en Pinterest se asemeja a la visión de un usuario que va recortando la realidad, aunque sin tijeras ni pegamento, y la organiza en su particular 
mural. Es un claro ejemplo de la necesidad de los individuos de ir adquiriendo pertenencias y de autorepresentarse a través de ellas» (Visa Barbosa, 2013).

Esta representación personal a través de los intereses aporta información importante para las organizaciones porque permite crear perfiles y "conocer" a sus seguidores, en función de sus preferencias visiblemente presentadas en los tablones de Pinterest. Brindando a las organizaciones y usuarios la oportunidad de relacionarse con los consumidores de una manera completamente nueva, permitiendo a las marcas no solo demostrar el valor que pueden aportar a la vida cotidiana de un cliente al ofrecer lo que el cliente está buscando, sino que también da la oportunidad de construir la lealtad del consumidor (Evans Cario, 2013).

Instagram. es una aplicación gratuita que se lanzó el 6 de octubre de 2010. En el primer año alcanzó los 27 millones de usuarios en el mundo (Liberos et al., 2014: 763), llegando a los 400 millones en el 2015 (Höhr, 2015). Entre las principales características de la Red se destaca la geolocalización, la movilidad y la aplicación de filtros que permiten mejorar las imágenes.

A nivel de marca, son varias las opciones que Instagram permite para interactuar con sus seguidores... Agregando un hashtag a las fotografías la marca puede recoger toda la actividad fotográfica que se ha compartido en Instagram para diferentes usos, como puede ser, el de realizar un concurso fotográfico (Liberos, et al., 2014: 763).

La aplicación, también, registra la opinión de los usuarios a través de los comentarios, me gusta y la mensajería interna y favorece a la generación de relaciones con los clientes. $\mathrm{Al}$ ser una red relativamente nueva existen pocos estudios referentes a su impacto en el ámbito empresarial y comercial, pero es evidente que el rápido crecimiento de Instagram en el mercado atrae a las diversas marcas que son aceptadas entre los usuarios.

You'Tube. Al igual que las fotografías los videos permiten crear una imagen en la mente de los usuarios, favoreciendo al proceso de decisión 
y compra. Youtube se consolida como uno de los iconos de referencia a nivel mundial en cuanto a la web social, porque permite ver, subir y compartir vídeos. Consecuentemente, en el ámbito empresarial es considerado como una herramienta de comunicación externa porque admite la publicación de vídeos referentes a la institución, eventos, productos y servicios con sus respectivas etiquetas, lo cual, genera visibilidad en la red. Además, consiente pautar publicidad en las redes sociales que se convierte en viral. El potencial de la nueva herramienta resulta de interés al servicio de las organizaciones (empresas e instituciones), que tienen la oportunidad de contar con su propio canal televisivo en Internet, un repositorio que reúne vídeos para ser comentados, para ser compartidos, para gustar y para fomentar la participación de los interesados (Costa-Sánchez, 2015: 86).

\subsubsection{Redes sociales}

Las redes sociales son aplicaciones online gratuitas en las cuales convergen varios usuarios ya sea de forma privada o pública con la finalidad de intercambiar información (contenidos, fotografías, vídeos, audio), o simplemente relacionarse con otros usuarios que tengan similares intereses. Las principales características de la red social son la interactividad, la participación y el compromiso voluntario para publicar en la Red. Gustavo Aruguete (citado en Di Placido, 2010) define el concepto de redes sociales: "como formas de interacción social, un intercambio dinámico entre personas, grupos e instituciones en contextos de complejidad. Un sistema abierto y en construcción permanente que involucra a conjuntos que se identifican en las mismas necesidades y problemáticas y que se organizan para potenciar sus recursos", este concepto lo complementa Campos (2008: 2):

"Entendemos las redes sociales como el concepto de comunidad, a través de la creación de redes de usuarios que interactúan, dialogan y aportan comunicación y conocimiento; tecnología flexible y ancho de banda necesario para el intercambio de información y estándares web de aplicación libre; y una arquitectura modular que favorece la creación de aplicaciones complejas de forma más rápida, a un menor coste. Mientras en la web 1.0 los usuarios eran meros receptores de servicios, en la web 2.0 producen contenidos (blogosfera), participan del valor 
(intercambio) y colaboran en el desarrollo de la tecnología. El proceso de comunicación genera, en definitiva, un flujo activo de participación”

En el ámbito empresarial, las redes sociales adquieren un papel estratégico en la comunicación, hacen posible establecer relaciones estrechas entre las organizaciones y sus stakeholders basadas en el compromiso y la relación interpersonal. En este sentido, lo importante no es tener presencia en Internet, sino conseguir ser parte de la conversación,

Las marcas tienen que dejar de hablar bien de sí mismas, eso ya no se lo cree nadie, deben de conseguir que sean los usuarios los que hablen bien de ellas y esto no se logra comprando supuestas audiencias y haciendo mensajes elocuentes y repetitivos, sino generando experiencias positivas y memorables, conectando emocionalmente, ayudándolas en algo que ellas valoren, y consiguiendo generar un vinculo afectivo con la marca: no por lo que dice sino por lo que hace (Rosales: 2010: 82).

Por tanto, no se trata, solo, de adaptar lo offline a lo online, sino de pensar que las redes sociales, no son controlables, son totalmente bidireccionales y conversacionales, no son canales creados para la persuasión, sino para las relaciones sociales, no es el sitio natural de las marcas, y deben esforzarse por respetar las normas (Alonso Mosquera, Bartolomé, y Viñarás Abad, 2014: 165).

Las marcas tienen tres maneras de aportar valor en las redes sociales (Interactive Advertising Bureau, IAB, 2009: 18):

- Generando contenido, se debe dar una información más amplía, de mayor calidad y más cercana de nuestra marca a los usuarios de las redes sociales. Internet es un espacio donde podemos exponer toda nuestra comunicación de una manera no intrusiva y de calidad para el usuario.

- Dotando al usuario de herramientas y aplicaciones, las marcas pueden desarrollar herramientas y aplicaciones que beneficien la relación del usuario con su producto. Aplicaciones online 
integradas en una red social, o no, que den información o faciliten la compra de nuestro producto.

- Haciendo que el usuario viva la experiencia de nuestra marca: no sólo posibilitando una experiencia directa de un producto o un acontecimiento (evento de marca) sino permitiendo tener un diálogo fluido con cualquier usuario. Responder a comentarios, y opiniones crea una experiencia con nuestros clientes.

Además, estas redes de intercambio constituyen una fuente de información sumamente importante, puede generar bases de datos con información detallada referente a la personalidad y estilo de vida de los usuarios, ya que ellos voluntariamente intercambian opiniones, recomendaciones, intereses, gustos, ocupación en su tiempo libre, motivaciones de compra, deseos, etc. Información que permite a las empresas conocer las tendencias del mercado.

Rosales (2010: 91) recalca que la presencia de una organización en una red social genera algunos beneficios, entre los más importantes señala:

- Permite conocer mejor a los usuarios al poder conversar con ellos al mismo nivel y sin intermediarios.

- Incrementa la capacidad de convocatoria y de transmisión del mensaje, incluso a veces llegando a tener un efecto viral.

- Genera ahorro en los costes de las comunicaciones.

- Aporta y requiere transparencia generando mayor credibilidad en el mercado.

Otra de las características fundamentales de las redes sociales para la implementación de las campañas de comunicación es la facilidad de segmentación que brindan permitiendo alcanzar el mercado objetivo. Los expertos reúnen a las redes sociales en tres grandes grupos:

- Redes profesioales: Estas redes son utilizadas con fines profesionales; permiten ampliar contactos en aéreas específicas, con la finalidad de relacionarse con usuarios, contratar especialistas, buscar empleo, participar de congresos y eventos profesionales. Se crearon varias redes profesionales a nivel mundial, incluso algunos países poseen su propia red. Pero, la 
más reconocida es Linkedin a la que se integraron profesionales provenientes de 200 países y se desempeñan en 170 sectores distintos. El uso de redes profesionales es difundido en Norteamérica y Europa, sin embargo, no se ha consolidado en Latinoamérica, por ser países con mayor penetración de Internet.

- Redes especializadas: en estas redes sociales verticales en los últimos años se ha registrado un crecimiento constante y desarrollo de diversidad de alternativas, este tipo de redes se especializan en una determinada actividad social o económica formando comunidades de personas con similares intereses. Las redes son aprovechadas en el ámbito de la comunicación porque permiten llegar a un público específico para ofrecer sus productos o servicios. En el caso del turismo destacan Tripadvisor y Booking.

- Redes generalistas Estas redes logran contactar a las personas haciéndolas visibles en la red, el usuario es activo y dinámico, comparte fotografías, música, vídeos y comentarios sobre diversas temáticas.

La red social Facebook ha crecido de forma veloz desde sus orígenes en febrero de 2004. Este importante crecimiento de la red influye para que las empresas incrementen notablemente la publicidad en la red social, generando mayores ingresos en publicidad. Las principales características que presenta esta red para su éxito es la flexibilidad, la adaptación, la evolución y la capacidad viral que alcanzan los contenidos, con estos antecedentes se debe considerar el Facebook como una herramienta de comunicación organizacional y adaptarse al modelo de comunicación. Es un espacio para comunicar y comunicarse, donde empresas y profesionales deben introducirse aceptando las reglas del juego, y para ello hay que comprender dos principios fundamentales: El usuario es el centro y el contenido es el rey. Bajo estas dos premisas se puede utilizar la herramienta para conseguir múltiples beneficios (Rodríguez, Bravo y Troncoso, 2009: 65).

Por tanto, al emplear estrategias de comunicación 2.0 es indispensable mantener una actitud y compromiso 2.0, es decir adaptarse a las necesidades del usuario, que en la era digital es quien va marcando el 
rumbo y las tendencias. En este sentido, hay que comprender que los usuarios que visitan las redes sociales se comportan de manera diferente al tradicional, entre las principales diferencias se destacan:

- El contenido que consume es generado por su lista de contactos.

- El usuario genera contenido para otros.

- El promedio de visita al sitio es mucho mayor incluso en un mismo día, y el número de páginas vistas mucho más elevado.

El motivo principal porque una persona visita una red social son las personas que la componen (Rodríguez, Bravo y Troncoso, 2009) por lo que es necesario diseñar un modelo de grupo o comunidad y definir la estrategia pensando en el usuario, sin saturarlo y basado en la comunicación. Para diseñar la estrategia Rodríguez, Bravo y Troncoso recomiendan a las empresas (2009: 73):

- Participar y conversar donde está el público objetivo.

- Responder a los comentarios y peticiones de información.

En la estrategia de contenido, se debe permitir:

- Ser comentado

- Ser consumido y compartido fácilmente

- Ser consultado y localizado fácilmente

- Que pueda ser seguido mediante suscripción

En Facebook, los grupos creados por los consumidores o las empresas proporcionan el foro idóneo para que pequeñas comunidades de personas con un interés común puedan comunicarse y expresarse en relación con dicho interés. Cualquier persona puede crear un grupo, e interactuar con otros usuarios, pero también existe la posibilidad de que empresas, organizaciones, famosos, marcas y productos puedan comunicarse con los consumidores que desean seguirles (Alonso Mosquera y Muñoz de Luna, 2014).

A manera de conclusión se puede afirmar que en la actualidad la comunicación organizacional on - line tiene múltiples herramientas para relacionarse de manera directa con su público objetivo, pero, es 
necesario un compromiso 2.0 por parte de las organizaciones, una gestión efectiva de las herramientas y la producción adecuada de contenidos enfocados en el usuario, para que provoquen la participación e interacción de los usuarios.

\section{Agradecimiento}

- La presente investigación se desarrolló en la Universidad Técnica Particular de Loja (Ecuador) con ayuda y aporte financiero de la Secretaría Nacional de Educación Superior, Ciencia, Tecnología e Innovación (Senescyt), de Ecuador, a través del Programa de Becas Docentes

\section{Referencias}

Alonso Mosquera, M., Bartolomé, Á. y Viñarás Abad, M. (2014). El uso de redes sociales y la construcción de la imagen de marca por los consumidores. En M. Carretón, y K. Matilla, La conducta interactiva de los públicos para las relaciones eficaces. Las relaciones en la comunidad y en las redes sociales (págs. 157 - 174). Zaragoza, España: Editorial UNE.

Ayestarán, R., Rangel, C. y Ana, S. (2012). Planificación estratégica y gestión de la publicidad. Conectando con el consumidor. Madrid, España: ESIC Editorial.

Campos Freire, F. (2008). Las redes sociales trastocan los modelos de los medios de comunicación tradicionales. Revista Latina de Comunicación Social (63), 287 - 293. Recuperado de http://www.ull.es/publicaciones/latina/_2008/23_34_Santiago /Francisco_Campos.html

Carrera, P. (2011). Join the conversation Variaciones sobre la conversación y la Red. Revista TELOS (88), 37 - 45.

Castells, M. (2005). La era de la información. Economía, Sociedad y Cultura. México: Siglo XXI Editores.

Castillo, A. (2004). Nuevas tecnologías y comunicación: análisis de la intranet como soporte de comunicación interna. En J. Lozada Díaz. (Ed.), Gestión de la comunicación en las organizaciones (pp. 271 - 288). Barcelona, España: Ariel Comunicación. 
Celaya, J. (2009). La Empresa en la web 2.0. Barcelona, España: Gestión 2000.

Costa-Sánchez, C. (2015). El cambio que viene Audiovisual branded content. Revista Telos (99), 170. Recuperado de https://telos.fundaciontelefonica.com/url-direct/pdfgenerator?tipoContenido $=$ articuloTelos\&idContenido $=201410$ 2812250003\&idioma $=$ es

De Moragas, M. (2012). Internet i canvis en el sistema de comunicació. Quaderns del CAC 38, 15 (1), 5 - 14. Recuperado de

https://www.cac.cat/pfw_files/cma/recerca/quaderns_cac/Q3 8_de_moragas.pdf.

De San Eugenio Vela, J. (2012). Aproximaciones teóricas y conceptuales para una definición del estado del arte de la comunicación de los destinos turísticos. Revista Andamios, 9 (20). Recuperado de http://www.scielo.org.mx/scielo.php?script=sci_arttext\&pid= S1870-00632012000300011.

Del-Fresno-García, M. (2014). Haciendo visible lo invisible: visualización de la estructura de las relaciones en red en Twitter por medio del análisis de redes sociales. El profesional de la información, 23 (3), 246 - 252. doi: 10.3145 / epi.2014.may.04

Di Placido, A. (octubre de 2010). Interactividad usuario-usuario y redes sociales online en el sector turístico. Análisis de las páginas web turísticas oficiales de las administraciones andaluzas. En A. Guevara Plaza, A. Aguayo Maldonado y J. Caro Herrero (coords.). VIII Congreso "Turismo y Tecnologías de la Información y las Comunicaciones” Turitec 2010, Malaga, España.

Domínguez Vila, T. y Araújo Vila, N. (2012). El fenómeno 2.0 en el sector turístico. El caso de Madrid 2.0. Revista Pasos, 10 (3), 225 237.

Evans Cario, J. (2013). Pinterest Marketing an hour a day. Indiana, EE. UU: John Wiley \& Sons, Inc.

Fernández-Cavia, J., Díaz-Luque, P., Huertas, A., Rovira, C., PedrazaJiménez, R., Sicilia, M. y Míguez, M. (2013). Marcas de destino y evaluación de sitios web: una metodología de investigación. Revista Latina de Comunicación Social, (68). doi: 10.4185/RLCS2013-993 
Fernández Poyatos, M., Aguirregoitia Martínez, A. y Boix Martínez, B. (2011). Camino de Santiago y Xacobeo 2010 en los portales turísticos de las Comunidades Autónomas. Revista Latina de Comunicación Social (67), 23 - 46. doi: 10.4185/RLCS-67-946-023046

García Gómez, J. (2001). Portales de internet: concepto, tipología básica y desarrollo. El profesional de la información, 10 (8), 4 - 13. García, M.L. y Núñez, P. (2009). Los bloggers y su influencia en la imagen de una marca. Revista Icono 14, (12), 242 - 252.

Recuperado de http://www.icono14.net/ojs/index.php/icono14/article/viewF ile/343/220.

Guerrero-Solé, F. y Fernández-Cavia, J. (2013). Activity and Influence of Destination Brands on Twitter: A Comparative Study of Nine Spanish Destinations. En Z. Xiang y I. Tussyadiah, Information and Communication Technologies in Tourism 2014 (págs. 227 - 237). Suiza: Springer International Publishing. Höhr, R. (2015). iRedes. Burgos, España. iRedes. http://www.iredes.es/mapa.

Interactive Advertising Bureau. (2009). Cuaderno de Comunicación Interactiva. El Libro Blanco. La Comunicación en Medios Sociales (8). Recuperado de http://www.iabspain.net/wpcontent/uploads/downloads/2012/02/8_LB_Comunicacion_ Medios_Sociales.pdf.

Jansen, B., Zhang, M., Sobel, K. \& Chowdury, A. (2009). Twitter Power: Tweets as Electronic Word of Mouth. Journal of the American Society for Information Science and Technology, 60 (11), 2169 - 2188. doi: 10.1002 / asi.21149

Koerbitz, W. y Önder, I. (2013). Destination Benchmarking with Geotagged Photographs. En Z. Xiang \& I. Tussyadiah, The Adoption of Pinterest for Destination Marketing: The Case of Austrian Destinations (págs. 201 - 211). Suiza: Springer International Publishing.

Kotler, P., Gertner, D., Rein, I. y Haide, D. (2007). Marketing internacional de lugares y destinos. México: PEARSON Educación.

Kozak, M., \& Baloglu, S. (2011). Managing and marketing tourist destinations: strategies to gain a competitive edge. New York, EE.UU.: Routledge. 
Liberos, E., Núñez, Á., Bareño, R., García, R., Gutiérrez, J. C., y Pino, G. (2014). El libro del marketing interactivo y la publicidad digital. Madrid, España: ESIC Editorial.

Macías, C. (2007). La revolución de los blogs de José Luis Orihuela. Revista sobre la sociedad del conocimiento, (5). Recuperado de http://www.uoc.edu/uocpapers/5/dt/esp/macias.pdf.

Marcos, M. y Codina, L. (2005). Posicionamiento web. Conceptos y herramientas. El profesional de la información, 14 (2), 84-99.

Martínez Villa, A. (2012). Turismo 2.0: Iniciando el Despegue. Oviedo, España: Septem ediciones.

Maurer, C. y Hinterdorfer, B. (2013). The Adoption of Pinterest for Destination Marketing: The Case of Austrian Destinations. En Z. Xiang \& L. Tussyadiah, Information and communication technologies in tourism 2014 (págs. 213 - 225). Suiza: Springer International Publishing.

Orihuela, J. (2010) El modelo ideal de interactividad es la conversación. Entrevista a José Luis Orihuela. En Revista Icono 14, pp. 9 - 21. Recuperado de www.icono14.net/monografico/interactividad.

Palazón Meseguer, A. (2001). Comunicación Web: el valor de los contenidos de la Red. Comunicar (17), 93 - 96.

Pinterest. (2016). About Pinterest. Recuperado de https://about.pinterest.com/es

Ramos Ostio, M. (2012). Relaciones Públicas. 2.0: El uso de los Medios Sociales en la estrategia de comunicación online de marcas ciudad españolas. Revista Internacional de Relaciones Públicas, 2(3), $71-90$.

Revista La Vanguardia. (2015, 18 de septiembre). Pinterest alcanza los 100 millones de usuarios. Revista La Vanguardia. Recuperado de http://www.lavanguardia.com/tecnologia/movilesdispositivos/aplicaciones/20150918/54436617771/pinterestmillones-usuarios.html.

Rodríguez, O., Bravo, S. y Troncoso, R. (2009). Facebook aplicaciones profesionales y de empresa. Madrid, España: Ediciones ANAYA Multimedia.

Rosales, P. (2010). Estrategia digital. Cómo usar las nuevas tecnologías mejor que la competencia. Barcelona, Espala: Ediciones Deusto. 
Socialbakers (2016). Directorio de estadísticas Twitter. Recuperado de https://www.socialbakers.com/statistics/twitter/

Scolari, C. (2012). Comunicación digital. Recuerdos del futuro. El profesional de la información, 21 (4), 337 - 340. doi:

10.3145/epi.2012.jul.01

Shareablee. (2015). Measuring What Matters. Recuperado de http://insights.shareablee.com/hs-fs/hub/478267/file2645979691pdf/ShareableeMeasuringWhatMattersWebinarFINAL.pdf?t=1 474296229716.

Túñez López, M. y Altamirano, V. (2015). La simetría interactiva de la comunicación organizacional. Revista DIRCOM, (108), 14 - 17.

Túñez López, M., Altamirano, V. y Valarezo, K. (2016). Collaborative tourism communication 2.0: Promotion, advertising and interactivity in government tourism websites in Latin America [Comunicación turística colaborativa 2.0: Promoción, difusión e interactividad en las webs gubernamentales de Iberoamérica].

Revista Latina de Comunicación Social, (71), 249 - 271.

DOI: 10.4185/RLCS-2016-1094.

Túñez López, M., Sixto García, J. y Guevara Castillo, M. (2011).

Redes sociales y marketing viral: repercusión e incidencia en la construcción de la agenda mediática. Revista Palabra Clave, 14 (1), 53 - 65. doi. 10.5294/pacla.2011.14.1.3

Túñez López, M. y Sixto, J. (2011). Redes sociales, política y

Compromiso 2.0: La comunicación de los diputados españoles en Facebook. Revista Latina de Comunicación Social (66), 210 - 246. doi: 10.4185/RLCS-66-2011-930-210-246

Visa Barbosa. M. (2013). El caso de la red social Pinterest: representación propia y coleccionismo virtual a través de imágenes. Revista VivatAcademia, (122), 92 - 105. 


\title{
Los prescriptores en la comunicación organizacional online: acciones, herramientas y estrategias
}

\author{
Francisco de Andrés Huertas \\ Universidad Complutense de Madrid
}

Sergio Mena Muñoz

\section{Univ. Complutense de Madrid / Europea Miguel de Cervantes}

PARA CITAR: Huertas, F. y Mena, S. (2018). Los prescriptores en la comunicación organizacional online: acciones, herramientas y estrategia. En TúñezLópez, M., Costa-Sánchez, C. y Valdiviezo, C. (Eds.), (2018). Comunicación Organizacional en entornos online. Gestión, actores y recursos. Cuadernos Artesanos de Comunicación, no 149 (pp. 107-130). La Laguna (Tenerife): Latina.

\section{Resumen}

El auge de los canalizadores de mensajes informativos o comerciales dentro del entorno 2.0 es un fenómeno que sigue una tendencia alcista desde hace unos años. Como descripción del estado de la cuestión en el panorama digital (objetivo de este capítulo) se ha procedido a realizar una reflexión acerca de su preeminencia y su peso en el esquema de comunicación organizacional a través del análisis de tres figuras de renombre. Realizando un seguimiento de las acciones, las herramientas y las estrategias seguidas por dos prescriptores internacionales y uno español se pueden vislumbrar las tendencias actuales y futuras que va a seguir el fenómeno en la comunicación digital.

Palabras clave: prescriptor, comunicación, internet, influencia, líder, opinión, campañas, reivindicativo. 
Un nuevo modelo de comunicación ha surgido en los últimos tiempos dentro del denominado entorno digital o paradigma digital que se podría denominar como "reivindicativo", tanto por sus métodos, como por su objetivo final, que normalmente suele ser de crítica hacia algún aspecto determinado de la ideología o del mercado. Dos son los conceptos relacionados con este fenómeno: la idea del personaje que influye en las opiniones y comportamientos del público y el líder o catalizador que mueve al seguidor a que realice algún tipo de acción predeterminada. En el primer caso se ha adoptado el término inglés "influencer" y en el segundo el de "prescriptor".

Un influencer es una persona con cierta o incluso elevada credibilidad sobre un tema determinado, llegando a convertirse en algunos momentos en un verdadero líder de opinión con capacidad de condicionar los comportamientos de la sociedad. De esta función de condicionamiento social, deriva la idea de que, en los últimos tiempos, estos personajes han sido vistos como potentes fuentes de ingresos para diversas marcas para poder expandir sus ideas o sus productos. Fijándonos en las conceptualizaciones del fenómeno, en este caso desde un enfoque periodístico y de marketing, destacan las palabras de la periodista Anna Solé Sans (2017) dice a través de las palabras de Josep María Fábregas, director y profesor del Master en Marketing Directo de la Universitat Pompeu Fabra de Barcelona School of Management que este fenómeno de los influencers en los últimos tiempos ha aumentado y las empresas encuentran en ellos una fuente de oro. Según palabras del propio Josep María Fábregas, "el caché de los influencers tendrá mucha relación con su audiencia, pero también con la capacidad de generar interacciones, que es lo que busca una empresa" (op. cit).

Sin embargo, es necesario remontarse casi una década para encontrar sus orígenes del concepto coincidiendo con el surgimiento de las redes sociales. Lo que comenzó siendo una herramienta para unir personas gracias a gustos comunes o aficiones, poco a poco ha ido "degenerándose" hasta convertirse en lo que hoy conocemos como persona con influencia en la red, un modelo de usuario dispuesto a abandonar sus ideales en beneficio de los intereses de una empresa o una compañía. Ha pasado de ser una plataforma que servía para darse a conocer a una forma de negocio, en muchas ocasiones, muy tentador. 
Destacable el artículo de Águeda A. Lorca (2015) titulado "Los influencers: pasado, presente y futuro; del watchdog a los tuits de 45 mil euros" donde se detalla este fenómeno de influencer, de dónde viene, qué es, y a dónde va.

\section{Concepto de prescriptor}

De manera parecida se expresa Núñez (2015) cuando describe la idea, el fundamento y la función de un prescriptor. "Es aquella persona o personalidad que tiene la habilidad de influir en un determinado público cuando comparte su opinión o valoración sobre algún producto, servicio o marca". Al igual que ocurre con los influencers, se trata de una figura importante a tener en cuenta por las marcas porque éstas buscan que transmitan y proyecten una imagen favorable de las mismas (Vallderrama, 2015) y cada vez son más las acciones de comunicación que buscan dirigirse desde una figura de renombre a un público influyente para que éste, a su vez y con el poder de recomendación, reenvío, transmisión, de espejo y de viralidad que tiene, difunda el mensaje positivo pretendido a sus seguidores. Estos líderes de opinión o prescriptores digitales "sean celebridades, youtubers o bloggers, ofrecen a las marcas en sus espacios online un amplio alcance gracias a los miles de seguidores con que cuentan”, según Castelló (2015).

La sutil diferencia entre unos y otros radica en que en el primer caso los influencers saben que son usados como herramienta de una marca para promocionarla sin caer en ningún conflicto ético al aceptar la regla del juego y abandonar (incluso) sus principios para trabajar para y por la marca. Sin embargo, un prescriptor ya es un líder de opinión por sus posicionamientos previos y si una marca decide apostar por su figura no se pretende ni se busca en ningún caso que abandone sus principios para moldarse al mensaje deseado.

Al contrario, sus principios (ideológicos, comerciales, éticos, etc.) son motivo de atracción $y$, por tanto, su abandono desvirtuaría completamente su figura y su influencia. 


\subsection{Antecedentes}

La aparición del prescriptor no es nueva. Desde la propia aparición como tal en el advenimiento de la primera revolución industrial, la publicidad ha recurrido desde sus orígenes con figuras de renombre para conseguir atraer la atención del público y enfatizar con ellos hasta conseguir el reconocimiento, la confianza y la adquisición final del producto o servicio. Conocen perfectamente el bien a promocionar y su reconocimiento social o profesional es garantía de empatía. El sector es una pieza incontestable y así en el tiempo ha sido habitual ver protagonizar diversas campañas a directores de bancos como prescriptores de productos financieros o a jugadores de un deporte determinado como imagen de una marca de ropa o material de ese deporte.

Gracias a su posicionamiento (recordemos que se trata de un constructo mental con base en una comparación con el resto de marcas de la competencia) las personas con reconocimiento pueden incidir e influir de manera crucial en la opinión general hacia un determinado producto o servicio. "Arrastran" con su elección a sus seguidores o a aquellos segmentos y nichos de mercado que le son afines. También, cómo no, su posición ideológica o política es tomada en cuenta por sindicatos y partidos políticos a la hora de recurrir a ellos como potenciador, dinamizador o catalizador de una determinada opción política.

\subsection{Evolución}

De los tiempos en que el prescriptor era una mera figura de referencia sin más al día de hoy en que se ha convertido en un catalizador de mensaje no ha pasado mucho tiempo. En los tiempos de la comunicación tradicional los recomendadores ajustaban sus mensajes a los canales de los medios analógicos, pero a día de hoy estos mismos interactuantes basan su actividad en una alta presencia en las redes sociales. Este hecho, muy paradigmático como paso del mundo analógico a lo digital, ha permitido crear una de las patas en las que se apoya la preeminencia y el renombre de los prescriptores: el número de seguidores. Si bien la manera de contabilizar la cantidad de 
seguidores que pudiera tener tal o cual figura de referencia, con la digitalización este hecho se ha diluido y las métricas son muy fiables y exactas.

En ese escenario, actualmente se ve que los prescriptores con comunidades de seguidores de cierto peso suelen recomendar un número concreto de marcas de terceros, siendo las relacionadas con la tecnología las más demandadas y preferidas por ellos. También el mundo de la restauración y las actividades de ocio y tiempo libre suelen ser objeto de deseo por parte de estas figuras públicas.

Sin embargo, no se debe olvidar ni despreciar otras herramientas de naturaleza digital que también son usadas por los prescriptores de marca y servicio. Sus opiniones no solo se esparcen por internet a través de YouTube o Facebook, sino que sitios como el buscador Google y sus comentarios de usuarios, redes como Instagram o Trip Advisor, blog especializados, foros o directamente webs con espacio para el comentario como Amazon también son herramientas de gran uso con resultados muy productivos.

Su influencia proviene de múltiples frentes de acción, pero en todos los casos se tiene muy en cuenta a la hora de evaluar su peso el número de conversaciones que son capaces de crear sobre un tema, cuantas personas siguen esa estela, los comentarios que emite y los que surgen a partir de su inclusión y la conversión en ventas, visitas o seguidores de otras redes o herramientas de la marca mencionada.

\subsection{Objetivos}

Objetivo principal

En primer lugar, como objetivo principal, pretendemos demostrar que el aumento del renombre de este tipo de figuras viene dado por un cuidado diseño y producción de diversas campañas de visibilización con mensajes diferentes, pero con el mismo método de promoción.

Objetivos específicos

Como objetivos específicos buscamos demostrar en primer lugar cómo este modo de actuación también consiste en un método de ganar 
dinero gracias a su repercusión. Por otro, describir a través de tres figuras y de algunas campañas diseñadas y producidas por ellos sus métodos de promoción.

\subsection{Metodología}

Para conseguir alcanzar los objetivos previstos se ha elegido poner en marcha una metodología consistente en analizar las campañas, la gestión de las mismas, el nivel de influencia por medio del número de visitas del objeto o medio elegido en un periodo de tiempo y el número de suscriptores que siguen a los prescriptores Casey Neistat, Banksy y la agencia de creatividad Vimema.

A través de estos análisis se incluirán los detalles referentes a las acciones más destacada realizadas por cada uno de ellos, las herramientas elegidas para su consecución y las estrategias seguidas con ellas.

\subsection{Actores objeto de la investigación}

El primero de ellos, es Casey Neistat, un conocido youtuber estadounidense, que además es director de cine y blogger ${ }^{2}$. Se ha procedido a analizar su actividad en sus redes sociales, concretamente, en su canal de la plataforma de YouTube (Neistat, 2017a), y dentro del mismo, sus dos campañas más reconocidas, tituladas "Bike Lanes by Casey Neistat" y "Ipod's Dirty Secret - from 2003". Como se ha indicado anteriormente, el esquema a seguir ha sido analizar el número de visitas de ambos videos en un periodo de tiempo comprendido entre el 27 de febrero y el 27 de marzo de 2017 y del mismo modo, exactamente el mismo procedimiento con el número de suscriptores del canal.

1 Youtuber: Aquella persona que crea y comparte contenido/material en la red social YouTube y que, normalmente, se encuadra dentro de una temática determinada.

2 Blogger: Dícese de aquella persona que comparte información en una plataforma denominada como "blog", con una actividad media de 2-3 publicaciones semanales, y que gracias a ello, recibe una cantidad económica. 
Casey Owen Neistat nació en Gales Ferry, Connecticut, el 25 de marzo de 1981. Es director, productor, video blogger, youtuber y empresario, cofundador de la red social Beme. Casey y su hermano, Van, son creadores de la serie de HBO The Neistat Brothers.

El segundo de los prescriptores es el artista callejero conocido como "Banksy", un artista del que no se conoce completamente su identidad, lo que le permite actuar desde al anonimato. Desde que comenzase con su actividad, la cual se podría definir como "fuera de lo común" (García, 2010), el artista nacido en Bristol en 1975 se ha visto inmerso en numerosas polémicas debido a su forma de actuación.

En este caso, se ha decidido analizar del mismo modo, dos de sus campañas más reconocidas. La primera de ellas, titulada "Art Sale", y que se encuentra compartida en YouTube, subido por el canal de Banksy NY, un canal del que no se sabe si es exactamente Banksy quien lo gestiona.

La segunda campaña a analizar corresponde con el parque de atracciones creado por el mismo autor, que recibe el nombre de "Dismaland Park", una clara referencia a los parques por todos conocidos de la compañía de Disney. En este caso, se trata de un parque de atracciones muy atípico, fuera de lo común, y el primer ejemplo lo encontramos en su slogan principal, el cual dice que se trata de "un parque temático familiar para anarquistas principiantes" (Banksy, 2015). Se trata como dice el propio autor de un parque temático inadecuado para niños.

El último prescriptor a analizar es la Agencia Creativa \& Production Vimema, con sede en Barcelona. Se trata de una agencia de comunicación y creación de contenido que se dedica a elaborar campañas para diversas organizaciones, y en este caso, nos centraremos en dos de ellas destinadas al Salón Erótico de Barcelona para sus festivales de los años 2015 y 2016 tituladas El Manifiesto de Nacho Vidal, correspondiente al año 2015 y Patria de 2016.

La empresa comenzó su andadura en 2009. Se trata de una agencia creativa especializada en internet que produce su propio contenido 
considerada como la que más impacto tiene en la red en España. Solo realiza campañas virales. La realizada sobre el Salón Erótico de Barcelona de 2016 recibió un León del Festival de Publicidad de Cannes.

\section{Investigación}

Como ya se ha indicado, existe una fina frontera entre la definición de influencers y la de prescriptor. Los primeros son capaces por sí solos de crear cierta repercusión en un gran número de personas sobre un tema concreto teniendo en la credibilidad una de sus armas o características más importantes. De lo que comente o hable acerca de un tema, una cuestión o una marca, el seguidor sentirá que, al venir ese mensaje de una fuente autorizada, es más confiable.

Podemos encontrar ejemplos muy significativos en el sector farmacéutico con la aparición de científicos comentando las ayudas que recibe su investigación de ciertas marcas para potenciar los valores de esa empresa y que su imagen de marca crezca en la mente del consumidor. La aplicación práctica se traduce en un mayor protagonismo a la hora de ir a una farmacia y preguntar por un producto en concreto.

Sin embargo, el prescriptor es capaz de generar la suficiente repercusión sobre una gran cantidad de consumidores potenciando el deseo de conocer más o incluso adquirir un producto o servicio.

La figura no es nueva, como sí lo serían los influencers. Hace muchos años que existe $y$ ha sido utilizada por multitud de marcas con variopintos ejemplos que van desde campañas de publicidad con una figura conocida como argumento principal de venta, hasta acciones de concienciación o de responsabilidad social corporativa en las que una figura preeminente lanza un mensaje que se pretende ser imitado. Si bien los actuales prosumidores ${ }^{3}$ son pequeños prescriptores que,

3 Un prosumidor es, según Alvin Toffler, acuñador del término (1992) un "consumidor que se involucra tanto en el producto que llega incluso a convertirse en parte activa de la creación del mismo". 
unidos, pueden ejercer una influencia social muy elevada, la inclusión de figuras sociales relevantes consigue este efecto en mucho menos tiempo y con menos coste-tiempo.

Estas figuras de reconocido conocimiento (algunas con prestigio añadido, otras no) suelen coincidir en que todas suelen ser especialistas en un sector concreto y que cuentan con un gran conocimiento del mercado y con una amplia experiencia con la que se han ganado su reputación a base de su trabajo. Además, son especialistas sobre un producto, con gran capacidad de analizar productos que les llegan a sus manos, gozando de gran influencia dentro de un nicho cerrado siendo capaces de influir sobre grandes audiencias y sobre otros colegas de profesión.

Los hay también los que pueden hablar de cualquier tema y generar debate, controversia o simplemente ser comentado, aunque también los hay que detectan ideas que bien podrían convertirse en tendencias, más allá de los que se convierten en abanderados de temas o marcas haciendo de embajador de la misma.

Según indica Castelló (2015) el consumidor actual, denominado por autores como Chiesa de Negri como fansumer o cliente apóstol (2005: 101) cuenta con canales de comunicación novedosos donde dar rienda suelta a sus opiniones, ya sean de índole político o comercial.

La estrategia seguida por los gabinetes de comunicación, de publicidad o de marketing de las marcas ha sido aprovechar el gran poder de prescripción y recomendación de expertos, líderes de opinión o famosos para enfatizar el recurso del apostolado sobre la audiencia. Agrawal y Kamakura (1995: 56) sostienen que las marcas "buscan generar confianza, empatía y credibilidad entre el público a través de estos consumidores influyentes" por lo que el uso de estos perfiles elegidos incrementa la credibilidad de los mensajes, aumenta el recuerdo y el reconocimiento de las marcas anunciadas, mejora la actitud hacia la organización que vende el producto, e incluso incrementa la probabilidad de compra. 
La asociación de un producto o una marca con un personaje famoso no es nueva y se basa en la dimensión aspiracional de la audiencia que sueña y tiene anhelos, así como en mecanismos de identificación con el personaje que ayudan a la formación del autoconcepto ideal.

\subsection{Acciones}

La campaña de Casey Neistat titulada Ipod's Dirty Secret - from 2003 el prescriptor nos muestra un "incidente" que tuvo con la compañía Apple. El protagonista llevaba ahorrando meses para comprarse el producto que iba a ser la revolución del momento, el primer IPod ${ }^{4}$. Tras dejar todos sus ahorros en él, descubre que, a los 18 meses, deja de funcionar, y tras ponerse en contacto con el Servicio Técnico de Apple, le comentan que es problema de la batería, que solo tiene una vida media de 18 meses, y que no pueden darle otra solución más que comprarse un nuevo. El caso recuerda peligrosamente a la crisis de reputación que la misma compañía sufrió años más tarde, en 2017, a colación de la vida útil de las baterías de los modelos de teléfono móvil iPhone y su obsolescencia ${ }^{5}$.

Ante esto, todos nosotros hubiésemos caído en el enfado y la rabia más que justificada, pero Casey Neistat, no. El protagonista decidió ir más allá, y se dispuso a hacer "daño" a la compañía de la manzana de otra manera mucho más original. Se "armó" con una lata de pintura en spray y una plantilla creada por él mismo, y con ello, recorrió toda la ciudad de Nueva York pintando todos los carteles promocionales del IPod con la frase "La duración de vida del IPod es de 18 meses".

El resultado de todo ello fue la caída en picado de las ventas de la marca, lo que provocó que finalmente decidieran darle un nuevo

4 IPod: Reproductor digital portátil de música, imágenes y videos, caracterizado por ser el primer terminal capaz de almacenar más de 300 archivos en un terminal tan pequeño. El primero de ellos fue lanzado por la compañía Apple en octubre de 2001.

5 Las quejas de los consumidores (probablemente alentada por el antecedente del caso de Neistat) hizo que Apple pusiera en marcha un programa de sustitución de las baterías. 
terminal para solventar los daños ocasionados. Un claro ejemplo del modus operandi de nuestro primer protagonista.

Analizando el número de visitas del video, el cual hay que decir que se encuentra en su canal secundario de YouTube, pasaron de 1.236.881 a 1.279.648, una cifra nada despreciable.

Por otro lado, analizando la otra campaña en cuestión, titulada Bike Lanes by Casey Neistat se observa cómo el señor Neistat tiene una mente prodigiosa. En este caso, en el video se puede observar como Casey va en su bicicleta y es parado y multado por la policía con 50 dólares (40,53 euros) por no circular por el carril bici, a lo que el protagonista le responde, que no puede ir por el carril bici porque hay un coche estacionado en doble fila que le impide el paso.

El policía le dice que lo siente pero que le tiene que multar. Indignado con lo ocurrido, Casey Neistat coge su cámara y decide grabarse circulando por el carril bici pase lo que pase, es decir, sin parar por cualquier obstáculo que en él se encuentre. Esto le lleva a chocarse contra señales de tráfico, camiones, y lo que es el auge del video y la escena final, contra un coche de la propia policía de Nueva York. Tras hacerse eco y llegar incluso a salir en la radio local, finalmente le devuelven sus 50 dólares, una cantidad que no significa nada en comparación a lo que es su objetivo, demostrar cómo hasta los propios policías, son los que no cumplen las normas.

Con dicho vídeo, Casey Neistat obtuvo una evolución de visitas que pasó de 18.654.706 a 18.845.535, nada más y nada menos que aproximadamente 191.000 visitas en un mes. Si se comparan ambas visualizaciones de ambos videos, se observa una gran diferencia de uno a otro, un claro ejemplo de cómo ha ido evolucionando y como poco a poco se ha ido convirtiendo en alguien más conocido y más seguido.

Sin embargo, es importante decir que estas dos campañas no son las que más visitas tienen. En este caso, el video que más visualizaciones tiene es el titulado The 21,000\$ First Class Airplane Seat, que cuenta con más de 35 millones de visitas. Una barbaridad. En dicho video, Casey Neistat se dispone a viajar de Nueva York a Dubái, y por un error 
informático se queda sin asiento, de manera que la compañía (Fly Emirates), le ofrece un asiento completamente gratuito en primera clase, un asiento valorado en 21.000 dólares (17.022 euros), y donde Casey nos muestra lo que es viajar en estas condiciones. Un nuevo ejemplo de cómo funciona la mente de este genio.

Gráfico 1. Evolución de los seguidores del canal de YouTube de Casey Neistat

Evolución Número Seguidores Canal Casey Neistat
$6,850,000$
$6,800,000$
$6,750,000$
$6,700,000$
$6,650,000$
$6,600,000$
$6,550,000$
$6,500,000$
$6,450,000$
$6,400,000$

Fuente: Elaboración propia

Por último, es importante recalcar que el aumento en el número de visitas implica una repercusión económica, la cual, según la normativa de la plataforma YouTube, y perfectamente descrita en el artículo de Ana Pérez Sánchez publicado en la página Finanzas bajo el título ¿Cuánto paga YouTube por cada visita?, corresponde a 1 dólar por cada 1.000 visitas (Pérez, 2016). Con estos datos, se obtiene que, por la suma de ambas visualizaciones de las campañas anteriormente descritas, el youtuber Casey Neistat se embolsó nada más y nada menos que la cantidad de más de 20.000 dólares (16.212 euros), una cantidad que a día de hoy sigue aumentando ya que los videos siguen teniendo visualización. 
No hay mejor ejemplo para demostrar cómo este tipo de comunicación, una comunicación reivindicativa, se trata de una fuente de negocio, y, considerada por muchos de manera más que justificada, una nueva forma de empleo. Estas cantidades, se corresponden a solo esas dos campañas, a las que habría que sumar los demás videos que ha subido a su cuenta, pero que no han sido analizados. En el periodo de análisis propuesto, el autor subió una cantidad total de 10 vídeos, un total de 30.822.269 visitas, lo que se refleja en 30.822 dólares (casi 25.000 euros), una barbaridad teniendo en cuenta que ninguno de esos 10 videos se encuentra dentro de su TOP 5.

En la campaña Art Sale Banksy decide montar un puesto de venta ambulante en las afueras de Central Park, en el que pone a un anciano al frente del "negocio". Lo curioso reside en que lo que se vende en el puesto en cuestión, son las propias obras originales de Banksy a un precio de 60 dólares (48,64 euros), algo que a simple vista parece normal, si no se supiese que las obras del artista están valoradas en miles de dólares.

Según avanza el video, se ve cómo no vende ninguna de ellas en las primeras 3 horas, hasta que una señora se detiene delante del puesto, y decide llevarse 2 cuadros, pero que se lleva con un previo regateo que le permite hacer un $2 \times 1$. Un poco más tarde, una joven de Nueva Zelanda se lleva otros dos, y al final, justo antes de cerrar, un chico decide llevarse cuatro con el pretexto de que se acaba de mudar a la ciudad y necesita algo para colgar en las paredes. Finalmente, para concluir el vídeo, se resume cuáles han sido los ingresos totales del día, una cantidad que asciende a 420 dólares (340,45 euros). Lo curioso de todo esto es que dichas obras normalmente se venden en subastas por miles de dólares.

Con este ejemplo, Banksy quiere hacer una dura crítica a la sociedad, una sociedad que el propio autor define en su propio libro titulado $W$ all and Pieces como "consumista que se deja guiar por los ideales de los demás antes que por los suyos propios” (Banksy, 2006: 23).

Se trata de una clara critica a los estándares establecidos por la sociedad. Si esas mismas obras que se vendían por 60 dólares, tuviesen su precio 
original, seguramente mucha más gente se hubiese parado e incluso puede que se hubiesen comprado más, pero lo que el artista pretende es todo lo contario. Demostrar cómo no somos conscientes de lo que nos rodea y cómo no sabemos darles a las cosas el verdadero valor que tienen. Con este video se desmonta el mito de que las obras de arte de calidad se encuentran únicamente en galerías de arte, es más, depende de cada uno de nosotros el darle el valor que de verdad se merece a las cosas que nos rodean.

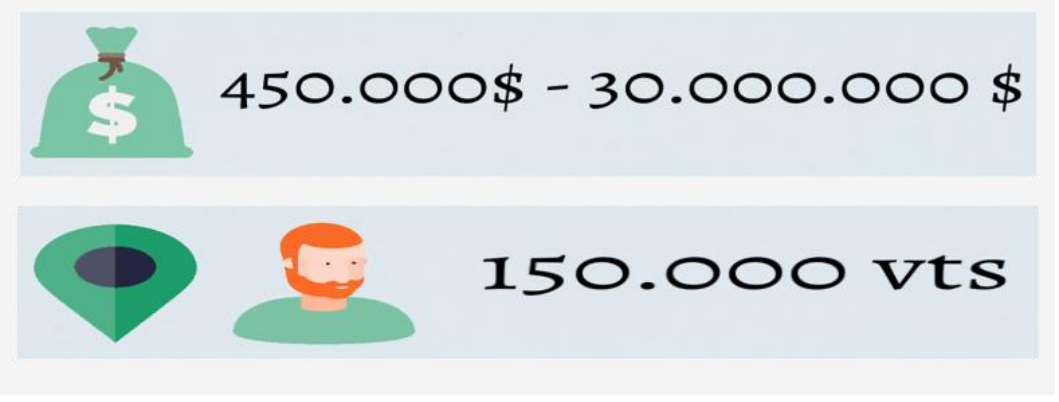

Figura 1. Recaudación y visitantes de la campaña "Dismaland Park". Elaboración propia.

Sobre el caso de la campaña Dismaland Park en este parque se puede observar nada más entrar algo que llama la atención, y es que, en comparación con Disneyland, con su fuente majestuosa en la entrada, en Dismaland observamos una fuente en ruinas en la cual hay estrellado un camión de la policía británica. El castillo se encuentra en ruinas, con un color gris humeante, a punto de derrumbarse, y una de las imágenes estrella del parque, una sirenita distorsionada adrede, debido al efecto que han causado las drogas en su cuerpo.

Como se puede observar, ambas campañas son un claro reflejo de cómo actúa este artista, un artista que en numerosas ocasiones se ha encontrado en busca y captura por la justicia del país británico, debido a la espectacularidad de sus campañas y su manera de "remover conciencias".

En cuanto al apartado económico, comenzando por la primera de las campañas analizadas, se puede contemplar como el video obtiene 
5.891.390 visualizaciones, lo que se traduce en aproximadamente unos 6.427 dólares (5.209 euros), a los cuales habría que añadir los ya conocidos 420 dólares (340,45 euros) que obtuvo por la venta de las obras en cuestión, una cantidad muy lejos de lo que suele recibir el artista por sus obras. Es más, en la película que narra su vida, la cual se titula Exit Throught the Gift Shop, se observa cómo organiza una exposición en Los Ángeles, a la que el propio artista acude camuflado como un visitante más, ya que nadie conoce su identidad, y a la que asistieron artistas de la talla de Brad Pitt y Angelina Jolie, los cuales compraron obras del artista por un valor cercano a los 100.000 dólares (81.060 euros).

Procediendo a analizar lo recaudado con su segunda campaña, el parque temático, lo primero de ello sería decir que el mismo se encontró abierto del 22 de agosto de 2015 al 25 de septiembre del mismo año, apenas un mes, ya que el artista decidió donar las instalaciones y las infraestructuras para dar cobijo a los refugiados que en ese momento llegaban a Europa, un nuevo ejemplo de cómo es Banksy y cuál es su intención detrás de todas estas campañas y maneras de actuar.

En consonancia, en el periodo de tiempo descrito en el que el parque se encontró abierto, miles de personas querían ser partícipes de esta experiencia, lo que provoco que las entradas llegasen al nivel de ser revendidas. Con una cantidad aproximada de 150.000 visitantes en un mes, las estradas oscilaban entre los 3 (2,43 euros) que costaban en las taquillas del mismo parque, hasta los 1.000 dólares (810 euros) que alcanzaban en la reventa. Esto implica una cantidad mínima de 450.000 dólares (364.770 euros) por un mes, un importe si todas las entradas hubiesen sido vendidas todas al precio de 3 dólares, pero si en un supuesto, de esas entradas, el $20 \%$ hubiesen sido vendidas en la reventa, se obtiene la ingente cantidad de 30.000.000 dólares (24.318.000 euros). Sobran las palabras. Un claro y nuevo ejemplo de cómo se trata de un nuevo modelo de comunicación, pero sobretodo, de un nuevo método de negocio.

Sin embargo, no son solo estas campañas las que han situado a Banksy en lo que se podría decir la cúspide de los nuevos formatos de 
comunicación de carácter reivindicativo. Entre otras, habría que destacar la que se titula El prisionero de Disneyland en la cual, el artista se encuentra en el parque temático y armado con una mochila, un mono naranja y un muñeco hinchable, sembró el pánico al hincharlo y colocarlo en la atracción del tren del oeste, con un ambiente como si un desierto de Arizona se tratase, con una bolsa negra en la cabeza, como si de un preso de Guantánamo se tratase.

No hace falta decir que fue algo que descolocó a todo el mundo y que le obligo a salir corriendo y esconderse en los baños del parque para poder cambiarse de indumentaria para no ser atrapado. Otro ejemplo de cómo es el artista, que, ya sea para bien o para mal, está en el foco de los comentarios de la sociedad y las instituciones.

Con respecto a la campaña El Manifiesto de Nacho Vidal de 2015 y "Patria" de 2016, ambas de la agencia Vimema y con un contenido subido de tono y que ha generado mucha controversia debido al contenido de sus imágenes, en la primera la grave voz del actor de cine para adultos se une a unas espectaculares imágenes que no hacen más que reafirmar el lema que quiere perseguir el video, el ya conocido "haz el amor y no la guerra". Lo complejo de las imágenes no es más que un pretexto para enseñarnos como dice que protagonista, que somos capaces de ver imágenes de guerra, de gente mutilada, de bombardeos, pero que luego nos ruborizamos y somos reacios a ver imágenes de gente practicando sexo y un tema que a día de hoy sigue siendo polémico, la homosexualidad.

Con dichas imágenes, la agencia busca mostrar una realidad que no todos quieren ver. Como en pleno siglo XXI aún tenemos tapujos y nos escandalizamos por ejemplo al ver a dos personas del mismo sexo amándose.

Estas imágenes fueron más que suficientes para que el video fuese censurado por YouTube durante las primeras 48 horas. Sin embargo, no se consiguió que el video continuase siendo visualizado, y según datos de la propia Agencia Vimema, en menos de 48 obtuvo más de 500.000 visitas. Nuevo ejemplo de la hipocresía de la sociedad, que se queja de lo que ve, pero no puede dejar de verlo. 
Sin embargo, las visitas seguían sumando y durante la fecha de análisis, hasta el 27 de marzo de 2017, tiene más de 8.000.000 de visitas, a las que habría que sumar las 1.432 .562 visitas del mismo video, pero en YouTube, subido por el propio canal del Salón Erótico de Barcelona, lo que significa aproximadamente 10.000 .000 de visitas. Un contenido al que no se está acostumbrado y que se critica, pero que no puede dejar de ser consumido.

Continuando con la otra campaña, en este caso, la que se corresponde al año 2016, con el título de Patria y en este caso protagonizado por la actriz de cine para adultos, Amarna Miller.

En este caso, Vimema dejan a un lado las imágenes tan espectaculares de la campaña anterior, pero opta por unas imágenes más directas y que para muchos llegan a ser más duras. En el video se ve a la actriz prestándose y diciendo cómo vivimos en un país tremendamente hipócrita, un país que a ella misma la llama puta, pero que se masturba viendo sus videos, un país en el que no se acepta el aborto, pero se celebra la muerte de otros seres vivos, refiriéndose a los toros, con una imagen durísima de un actor vestido de torero acariciando con las manos llenas de sangre la cara de un bebe.

Del mismo modo también se ataca a otros sectores, como es la iglesia, donde nos muestra a un cura bailando y en ropa interior acompañado de la idea de que los que se supone que son guardianes de la moral son los más peligrosos. Muchos temas que a día de hoy siguen siendo tabú o incluso ignorados, a pesar de considerarnos un país tolerante, pero que con estas imágenes se observa que no.

El colofón del video es la última frase que resume a la perfección el contenido del mismo, y que no deja indiferente a nadie diciendo que "vivimos que un país asquerosamente hipócrita, pero algunos, no nos rendimos" (Miller, 2016).

En este caso, según datos de la propia agencia, el video ha alcanzado un total de casi 24.000.000 de visualizaciones en todas sus plataformas, tanto YouTube como la página de la propia Agencia Vimema, en 
apenas 8 meses. Unos datos que podrían equipararse a los prescriptores anteriores, de manera que se podría decir que la propia agencia podría ser considerara como un influencer/ youtuber más.

Atendiendo al aspecto económico, si se juntasen las visualizaciones de ambas campañas, si computasen de igual manera que si se tratase de un video subido a YouTube, se obtendría una cantidad de aproximadamente 34.000 euros por ambas campañas. Estas cantidades únicamente se refieren a estas dos campañas analizadas, pero si nos centramos en la actividad genérica de la Agencia Creativa \& Production Vimema, según datos ofrecidos por el diario Expansión en relaciona la actividad de la misma en el año 2016, se observe que obtienen una facturación cercana a los 500.000 euros anuales.

En definitiva, si se comparan los prescriptores analizados entre sí, se ve como algunos destacan por encima de otros, pero todos manejan unas cantidades económicas descomunales. Algo que no es posible obviar a día de hoy y que no permite que se niegue que se trata de un nuevo método de comunicación de negocio.

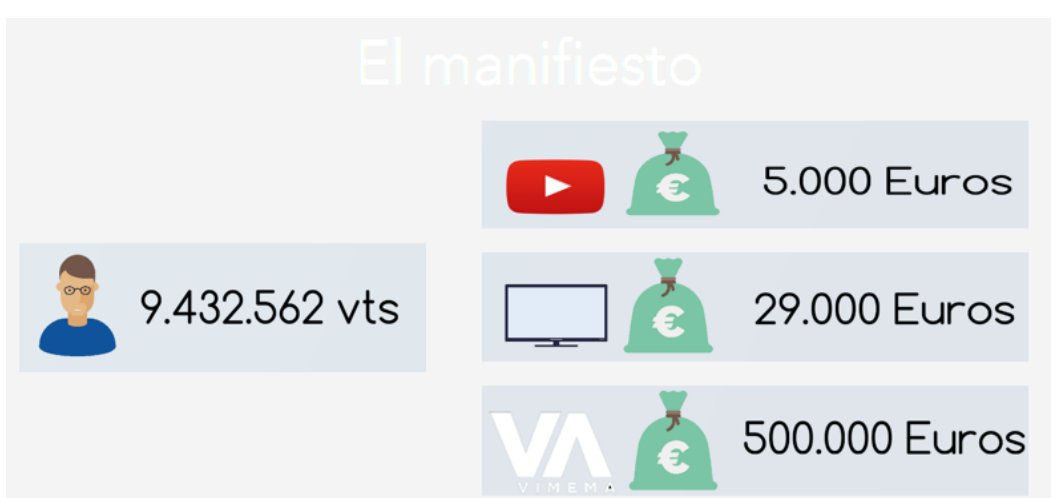

Figura 2. Visitas y recaudación en YouTube, en otras plataformas y en la web de Vimema de la campaña El manifiesto. Elaboración propia.

Analizando las acciones de los protagonistas en cuestión, observamos un nexo común a todos ellos, la búsqueda de la notoriedad y de hacerse eco ante una situación determinada. Con sus diferentes acciones, se busca el exponer una situación, cada uno de ellos en su respectivo modo, pero que, como se ha mencionado anterioridad, comparte un nexo común a todas ellas, el alzar la voz, o en este caso, "pasar a la acción" ante un acontecimiento de carácter reivindicativo 
Todos ellos buscan con su respectiva forma, poner sobre el papel una situación, hecho o acontecimiento que para ellos es necesario dar a conocer. Dar voz a algo que para el resto de los mortales pasa desapercibido o que simplemente no se le da la importancia que se merece o que ellos creen conveniente. Gracias a sus acciones, existe la posibilidad de ponerle "rostro" a dichas cuestiones a tratar, de manera que se podría decir que, con ello, encontramos a los protagonistas de esa cuestión que se defiende, y que, en todos ellos, persigue un fin común y a día de hoy, poco tratado. Una comunicación reivindicativa con la que gracias a ella surgen temas de debate que antes no nos habíamos parado a analizar.

\subsection{Herramientas}

Analizando el modo, el cómo defienden esas ideas que buscan mostrar a los demás, se puede observar que se trata de un método poco común. Unas herramientas que no han sido del todo explotadas y que, vistos los resultados de las mismas, son igual o incluso más efectivas que los métodos tradicionales.

A diferencia de la concepción predominante de actuación a modo de "queja", se observa que los protagonistas buscan cambiar sus respectivas situaciones desde un punto de vista diferente, un punto de vista que se podría denominar como más "actual", conforme a unos cánones de evolución tecnológica que se han ido produciendo en los últimos años.

Una manera de remover conciencias, partiendo desde las herramientas básicas que manejamos todo el mundo, todos los días, y a todas horas. Las redes sociales y nuestro día a día en la calle (grafitis, vídeos compartidos, un simple paseo...)

Son conscientes de la importancia que las nuevas tecnologías juegan actualmente, y ven en ello una oportunidad para dar a conocer aquello que buscan mostrar a los demás. Desde la sencillez de grabarse con un teléfono móvil, o utilizar una simple lata de pintura, hasta diseñar un 
decorado donde mostrar diferentes situaciones dispares, pero que comparten un objetivo final común, el "aquí y ahora"

Todo ello, reafirmado y corroborado por la fuerza de esas redes sociales, de esas plataformas no tan explotadas para estos fines, y de una de las herramientas de propagación más importantes usadas durante toda la historia, el denominado "boca a boca", pero al que habría que elevar a la máxima potencia, gracias a ese "compartir" ese contenido por todos y para todos. Algo, que seguramente estuviese premeditado por los protagonistas

\subsection{Estrategias}

Para llevar a cabo todo lo anteriormente mencionado, los protagonistas elaboraron un plan previo donde nada quedaba al azar. Desde el momento en el que se les presenta el problema en cuestión, hasta que se decide el método o la forma en la que pasar a la acción, existe lo que se podría decir como un estudio de campo previo, que pasa desde ver dónde se encuentran los carteles de una determinada compañía, al alquiler de un puesto de venta callejero para exponer obras, pasando por analizar los horarios de los vigilantes de seguridad de un parque temático para que todo funcione a la perfección.

Una vez realizada la acción, la parte más compleja y a la que más medios se dedicaron, sin embargo, la que menos repercusión tuvo en ellas, ya que de nada sirve todo lo hecho si no se expande como la pólvora, ahí entran en acción las herramientas fundamentales en todo ello, la pieza clave de todo, la propagación.

Conscientes de la fuerza de sus acciones y del potencial, deciden compartirlo en diferentes canales, como pueden ser radio, televisión, plataformas digitales, donde realmente pasan de ser los protagonistas a meros espectadores.

Lo realmente llamativo de todo ello es precisamente eso, desde ese momento, los protagonistas en cuestión pasan a segundo plano dando entrada a los seguidores o followers, que serán los encargados de propagarlo gracias a ese, boca a boca, de una forma más tradicional o 
más evolucionado, pero con la diferencia de que, sirviéndose de las nuevas tecnologías, será mucho más rápido y efectivo.

\section{Conclusiones}

Tal y como se propuso en la parte introductoria, el objetivo principal perseguido consistía en demostrar que el aumento del renombre de este tipo de figuras viene dado por un cuidado diseño y producción de diversas campañas de visibilización con mensajes diferentes, pero con el mismo método de promoción.

Por medio de la descripción del número de visitas lo demuestra, lo que podría ser un claro indicador del mismo. Se trata de un acontecimiento que hace diez años no sería viable ni creíble, pero que a día de hoy es una realidad muy patente.

Importante decir que se ha optado por dejar a un lado al prescriptor de hoy día, aquel que comparte un contenido sin ningún propósito concreto, más que el económico. Los cuales, manejan grandes cantidades de dinero, debido al gran número de visitas que reciben de un público que rara vez supera la mayoría de edad.

También como objetivos específicos se buscaba demostrar en primer lugar cómo este modo de actuación también consiste en un método de ganar dinero gracias a su repercusión.

Se ha observado cómo además de demostrar un claro auge de este tipo de comunicación, las cantidades económicas que se manejan son espectaculares, lo que ha permitido a muchos de ellos dedicarse penamente a estas campañas, ya que el beneficio económico que les repercute les da para vivir de ello. En este caso, se ve cómo parte de los beneficios, algunos los destinan a obras sociales (Banksy) y otros para su propio beneficio e inversión personal (Casey Neistat, Vimema)

Además, se pretendía describir a través de tres figuras y de algunas campañas diseñadas y producidas por ellos sus métodos de promoción. Como hemos visto, se ha realizado un recorrido a diversas campañas de los tres sujetos analizados en las que se han descrito maneras 
diferentes de llamar la atención, de sobresalir sobre el resto en un panorama comunicacional actual en el que la oferta de canales y mensajes de signo y naturaleza similar han hecho recargar en exceso el mercado.

En los tiempos de lo políticamente correcto, del libre acceso a una cantidad inabarcable de mensajes e información, del neoliberalismo comercial donde la ética se ha dejado a un lado junto con el humanismo, del individualismo, de la doble moral y de la paradoja del mundo feliz pero aislado en medio de la gente usar principio en comunicación clásicos para convertirse en referentes de opinión digital es todo un logro.

A través de los ejemplos vistos podemos llegar a la conclusión de que lo contra-tendencia sigue siendo efectivo para destacar, que al final el dinero es un fin codiciado a pesar del mensaje y que la audiencia, aunque haya cambiado el medio, sigue persiguiendo a una figura relevante que les guíe y les haga sentirse parte de una comunidad, aunque sea virtual.

\section{Referencias}

AA.VV. (En línea): "Directorio de Empresas. Vimema Productions SL" en Expansión en: http://www.expansion.com/directorioempresas/vimema-productions-sl 8016556 M59 08.html [fecha de consulta: 8 de mayo de 2017]

AA.VV. (2017a): "Banksy, parece que al fin se ba descubierto su identidad" en: http:/ / culturainquieta.com/es/inspiring/item/12215-banksyparece-que-al-fin-se-ha-descubierto-su-identidad.html [fecha de consulta: 8 de mayo de 2017]

AA.VV. (2017b): Vimema / Creative Agency \& Production

Company. 9 de mayo de 2017, de Vimema Sitio web: http://www.vimema.com/

Banksy (2006): Banksy: W all and Piece. Reino Unido. Secker and Warburg

BBC, Redacción (2015): La desesperación por ver Dismaland, el parque de 'diversiones' de Banksy, en $B B C$ en: 
http://www.bbc.com/mundo/video fotos/2015/08/150821 dismaland bansky $\mathrm{lb}$ [fecha de consulta: 29 de abril de 2017] Castelló, A. (2015): Del prescriptor al marketing de influencia. Observatorio Comunicación en cambio. Universidad de Alicante. En http://comunicacionencambio.com/delprescriptor-al-marketing-de-influencia/ [fecha de consulta: 29 de abril de 2017]

Castelló Martínez, A. y del Pino Romero, C., C. (2015). Prescriptores, marcas y tuits: el marketing de influencia. Revista Internacional de Investigación en Comunicación aDResearch ESIC. No 12 Vol 12. Primer semestre, enero-junio 2015. Págs. 86 a 107

Chmielewski, D. C. (2018): YouTube Personality Casey Neistat Departs Beme, Which Folds Into CNN Digital en http://deadline.com/2018/01/youtube-star-casey-neistatdeparts-beme-1202269466/ [fecha de consulta: 28 de abril de 2017]

Fine Art, Beeb. (2016): Banksy 'Exit Through the Gift Shop en YouTube en: https://www.youtube.com/watch?v=GSz7kq0Qo7o [fecha de consulta: 28 de abril de 2017]

García, T. (2010): Banksy: La bistoria de una leyenda en NeoTeo en https://www.neoteo.com/banksy-la-historia-de-una-leyenda/ [fecha de consulta: 28 de abril de 2017]

Koch, T. (2015): Banksy cierra con éxito Dismaland y lo convierte en un refugio para inmigrantes, en El País, en: http://cultura.elpais.com/cultura/2015/09/28/actualidad/144 3434486 924295.html [fecha de consulta: 29 de abril de 2017]

Llorca, Águeda A. (2015): Los influencers: pasado, presente y futuro; del watchdog a los tuits de 45 mil euros, en Genbeta en:

https://www.genbeta.com/a-fondo/los-influencers-pasadopresente-y-futuro-del-watchdog-a-los-tuits-de-45-mil-euros [fecha de consulta: 18 de abril de 2017]

Neistat, Casey (2016): The 21.000\$ First Class Airplane Seat, en YouTube. en:

https://www.youtube.com/watch?v=84WIaK3bl s [fecha de consulta: 15 de marzo de 2017]

Neistat, Casey. (2015). Canal Secundario YouTube, 2017, de YouTube Sitio web: https://www.youtube.com/user/caseyneistatclassics/featured 
Neistat, Casey (2014): Ipod's Dirty Secret - from 2003, en You'Tube, en: https://www.youtube.com/watch?v=SuTcavAzopg [fecha de consulta: 7 de marzo de 2017$]$

Neistat, Casey (2011): Bike Lanes by Casey Neistat en YouTube en: https://www.youtube.com/watch?v=bzE-IMaegzQ [fecha de consulta: 7 de marzo de 2017]

Neistat, Casey. (2010). Canal Principal YouTube. 2017, de You'Tube Sitio web: https://www.youtube.com/user/caseyneistat

Núñez, V. (2015): ¿Qué es un prescriptor?, en Diccionario de términos. https://vilmanunez.com/que-es-un-prescriptor/ [fecha de consulta: 28 de abril de 2017]

NY, Banksy (2013): Art Sale, en YouTube en: https://www.youtube.com/watch?v=zX54DIpacNE [fecha de consulta: 28 de abril de 2017]

Pérez Sánchez, Ana (2016): ¿Cuánto paga YouTube por cada visita? en Finanzzas en: http://www.finanzzas.com/cuanto-pagayoutube-por-cada-visita [fecha de consulta: 14 de abril de 2017]

Salón Erótico de Barcelona. (2015): El manifiesto de Nacho Vidal / SEB APRICOTS 2015, en YouTube en: https://www.youtube.com/watch?v=Gm8PoV4yWDU [fecha de consulta: 7 de mayo de 2017$]$

Salón Erótico de Barcelona. (2016): Patria - Salón Erótico de Barcelona Aprictos 2016, en YouTube en:

https://www.youtube.com/watch?v=6om5nTVyQlg [Fecha de consulta: 5 de mayo de 2017]

Solé Sanz, Anna (2017): ¿Para qué sirve un influencer? en La Vanguardia en:

http://www.lavanguardia.com/economia/management/201701 26/413687934411/para-que-sirve-influencer.html [fecha de consulta: 17 de abril de 2017]

Toffler, A. (1992): La tercera ola. Barcelona: Plaza y Janés.

Valderrama Santomé, M., y Niño, J., y Gonzálvez Vallés, J. (2015).

Nuevos prescriptores para el público joven en el entorno web 2.0. Opción, 31 (2), 1105-1128. 


\title{
La comunicación como pieza clave en la gestión de públicos
}

\author{
Cesibel Valdiviezo \\ Universidad Técnica Particular de Loja \\ Vanessa Duque \\ Universidad Nacional de Loja
}

\begin{abstract}
PARA CITAR: Valdiviezo, C. y Duque, V. (2018). La comunicación como pieza clave en la gestión de públicos. En Túñez-López, M., Costa-Sánchez, C. y Valdiviezo, C. (Eds.), (2018). Comunicación Organizacional en entornos online. Gestión, actores y recursos. Cuadernos Artesanos de Comunicación, no 149 (pp. 131-156). La Laguna (Tenerife): Latina.
\end{abstract}

\section{Resumen}

Los públicos han dejado de ser consumidores de información para convertirse en generadores de contenidos y creadores de información que, gracias a herramientas de comunicación digitales, hacen posible una amplia divulgación de lo que generan. Esto ha dado lugar a que los departamentos de comunicación vuelvan a repensar las dinámicas y se trabaje en una comunicación integrada para fidelizar a los públicos internos y lograr un posicionamiento en los externos. El contexto en el que se desenvuelven las organizaciones exige una priorización de la comunicación interna para promover el compromiso del empleado y la identificación de los colaboradores con la organización hasta llegar a construir embajadores de marca.

Palabras clave: comunicación integrada, Dircom, Marcom, engagement laboral. 
Las preferencias de los públicos, las nuevas formas de consumo de información y comunicación, la aparición de nuevas y modernas plataformas tecnológicas, son algunos de los factores que hacen posible que la comunicación evolucione y esté en permanente metamorfosis. Las organizaciones demandan que sus procesos de comunicación se actualicen y se reinventen frente a las exigencias de los públicos para cuidar del branding e imagen de la institución.

Actualmente, los diversos públicos han dejado de ser observadores de información y se han convertido en generadores de contenidos y creadores de información, que gracias a diversas herramientas de comunicación digitales hacen posible el traslado de manera inmediata, logrando alcance e influencia en otros públicos y promoviendo en muchos casos la compra de un producto o servicio.

Ante esta realidad de evolución permanente, las instituciones ven la necesidad de contar con áreas de comunicación y con profesionales de diferentes conocimientos para no solo lograr eco en los medios de comunicación, si no, buscar otras formas de comunicar a los públicos a través de plataformas digitales, logrando así impactos positivos en la comunidad donde geográficamente se ubica. Estas áreas de comunicación deben trabajar de manera coordinada con otros estamentos dentro de la organización, pero también cuentan con independencia y autonomía, para tomar decisiones relacionadas al campo de la comunicación.

Cuando se habla de comunicación institucional, Caprioti expresa que todo lo que la empresa comunica recae en su imagen y la coloca como un miembro de la sociedad, como un sujeto social (Villafañe, 2001: 86).

De la misma manera, la gestión de la comunicación por ningún motivo puede ser solamente estética, tampoco debe responder a planteamientos intuitivos (Losada, 2002: 53). Hoy en día en cualquier empresa es imposible prescindir de un departamento de comunicación, su labor debe ser estratégica a nivel interno y externo y debe involucrarse en todos los niveles institucionales. La comunicación es el corazón de la organización. Es desde ahí donde se puede mostrar la esencia de la institución. 
La comunicación es el instrumento esencial para establecer relaciones duraderas con los públicos a través de permanentes diálogos, donde la empresa genera contenido, los públicos reaccionan a ellos. Incluso es muy probable que, a través de éstos contenidos, se puede estar generando fidelización de los públicos hacia la empresa, algo tan difícil de lograr, pero tan valioso e importante para las marcas.

Paralelo a ello, el profesional que trabaja en comunicación debe estar en constante crecimiento y actualizado en función de nuevas tendencias de mercado y comunicación. Años atrás, la responsabilidad para este profesional estaba centrada básicamente en la relación con los medios de comunicación, dando resultados sobre la aparición de la marca en prensa, radio y televisión, espacios que predominaban el mercado.

Actualmente, su labor está direccionada hacia un modelo de gestión integrada, hacia la generación de contenidos de valor para diferentes plataformas digitales y tradicionales. Pero su tarea debe centrarse especialmente, en generar una comunicación más humanizada desde la organización hacia los diferentes públicos.

Las organizaciones deben ser conscientes que la gestión de la comunicación cumple un papel muy importante para su crecimiento económico, posicionamiento de marca y sostenibilidad en el mercado. Por tanto, es vital el trabajo de un equipo de comunicación que realice la labor al interior y exterior de la organización, para lograr mantener conectados a los públicos con la organización. "La comunicación debe ser considerada como una de las prioridades organizacionales, frente a las transformaciones mundiales y a la revolución tecnológica de la información y debe ejercer un poder expresivo en el día a día de la vida organizacional y en los procesos de gestión participativa" Valarezo, Valdiviezo y Córdova, 2015)

\section{Comunicación integrada}

A pesar de varios intentos por unificar dinámicas de trabajo, la relación entre el marketing y la comunicación organizacional era distante. Los profesionales que cumplían estas funciones se veían separados por 
diferencias que aparentemente nunca serían fusionadas, lo que hoy marca totalmente el campo de la gestión de la comunicación.

Pues esto, no va más y quienes trabajan en marketing y comunicación organizacional se han visto obligados a integrar sus trabajos para lograr un mejor posicionamiento de la marca de su empresa. Se combinan acciones de publicidad, promoción de ventas, marketing directo, ventas personales, comunicación digital, relaciones públicas, acciones de relacionamiento y visibilización con públicos objetivos; con el objetivo de construir una comunicación integrada y generar mensajes y contenidos que se fortalezcan entre si y juntos construir una única estrategia de posicionamiento y fidelización de la marca, que también recae como resultado positivo en la venta del producto.

La Asociación Americana de Agencias de Publicidad, define la comunicación integrada de marketing como "una disciplina, la cual consiste básicamente en la aplicación del conjunto de herramientas de mercadeo y comunicación, reconociendo el rol estratégico de cada una y combinándolas" (AAAP, 2018), en un plan integral para ofrecer un impacto comunicacional mucho más fuerte.

Existen muchas maneras de llegar al público meta, sin embargo, los consumidores eligen un producto por encima del otro, y esto lo hacen por muchas razones, entre ellas: fidelidad, por lo que saben del producto, por las experiencias vividas al consumirlo, e incluso ahora por los contenidos y la estrategia que la organización ha implementado para conectar con ellos como consumidores. Por tanto, predomina una comunicación integrada que para el cliente o consumidor es vista como una sola comunicación.

Son innumerables las opciones que los públicos tienen al momento de elegir un servicio o un producto y las mismas marcas compiten para tener mejores ventas en sus negocios. Pero es innegable admitir que los públicos han cambiado sus hábitos de consumo de información, la diversidad de plataformas también hace posible que esto suceda, entonces es ahí cuando las marcas deben adaptarse a dichos cambios generacionales por las tendencias de comunicación. 
Cuando se habla de comunicación integrada, se hace referencia a que desde la organización se debe poner mayor interés en la construcción de mensajes que se difunden a los públicos, percatándose que estos sean tan sólidos y bien elaborados que generen valor y una fuerte relación de empatía hacia la marca.

Para el estudioso, Tom Duncan, director del programa de comunicaciones integradas de marketing de la Universidad de Colorado (citado en Sarasola, 2018), existen beneficios de las comunicaciones integradas en el ámbito organizacional y nos propone un modelo de 5 principios básicos donde muestra como la comunicación integrada genera la sinergia necesaria para establecer relaciones y que se explican más adelante.

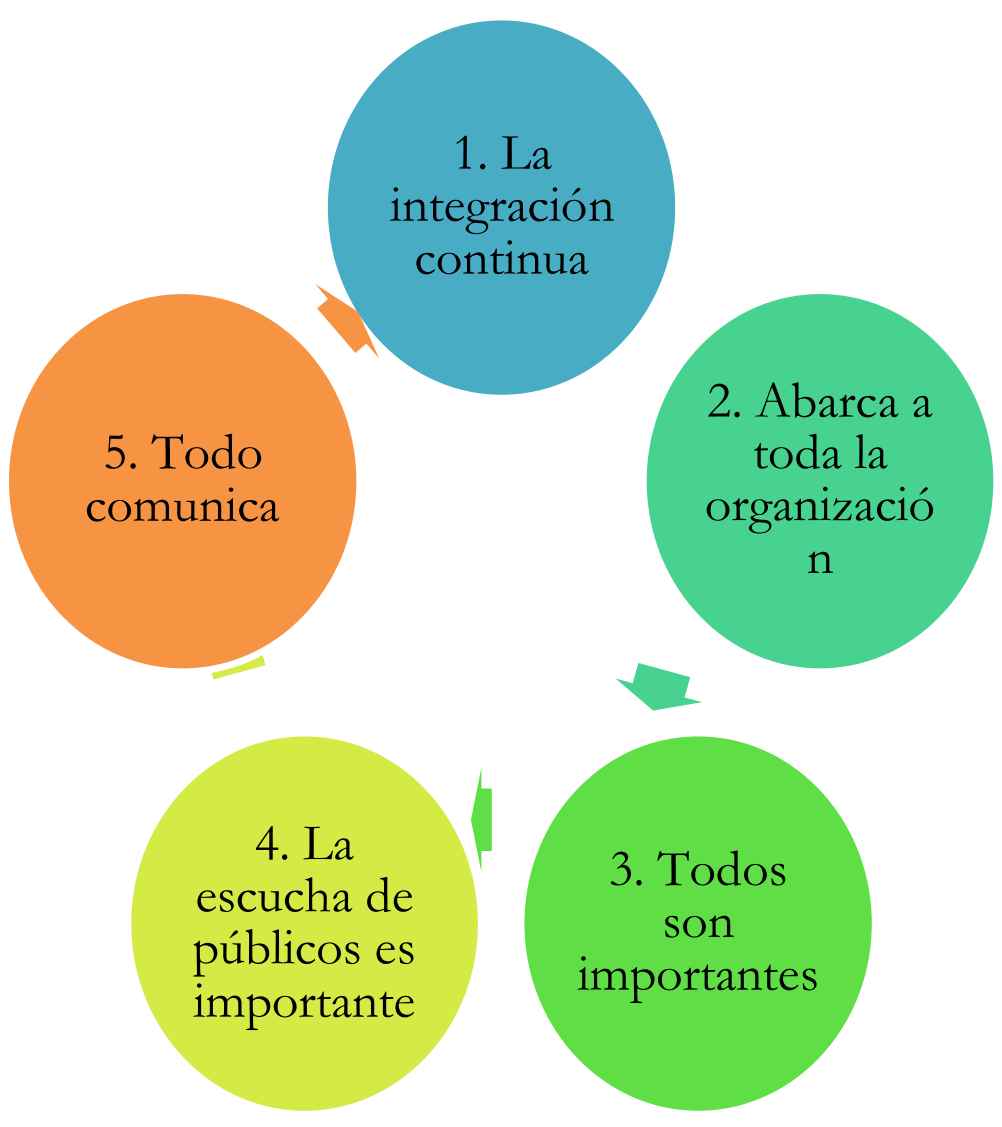

Figura 1. Principios básicos en el modelo de comunicación integrada. Elaboración propia. 
Este modelo de 5 principios básicos expresa que cada elemento tiene una razón de ser:

1. La integración continua: refiere a que la integración debe ser continua, y para ello, es fundamental que las organizaciones utilicen varios niveles de integración.

2. Abarca a toda la organización: es un proceso interfuncional, no es una simple función departamental, sino que debe abarcar a toda la organización.

3. Todos son importantes: en este proceso todos son importantes, involucra a los clientes, empleados, accionistas, competidores, vecinos, es decir, el entono en general.

4. La escucha de públicos es importante: el proceso de escucha es importante; por lo tanto, la retroalimentación de los públicos internos y clientes se convierte en clave de este proceso.

5. Todo comunica: todo lo que nuestros clientes ven, comunica y esto provoca un impacto.

A través de ello, se evidencia una comunicación integrada con mejores beneficios para las organizaciones, que deben adaptarse a esta evolución de las comunicaciones integradas, como un mecanismo de permanencia en el mercado y donde los públicos cada vez son más exigentes de la transparencia de su gestión y el consumo de información.

Ahora nos acercaremos de manera más profunda en entender que que ha pasado con la Dirección de Comunicación, y vemos que una nueva teoría denominada Marcom ha aparecido e integra el marketing y la comunicación en las organizaciones.

\section{Evolución del Dircom al Marcom}

Para 1919, año en el que Edward Bernays utilizó el término consejero de relaciones públicas, las empresas estratégicamente utilizaban la comunicación para mejorar la imagen deteriorada de sus empresas, por inconvenientes económicos poco éticos, por la mala administración de las empresas y conflictos entre países y problemas laborales. 
A partir de esto, las empresas e instituciones públicas y privadas, empiezan a crear estructuras de comunicación, en un principio escasas de personal y equipos para la producción de contenido. Los primeros resultados se reflejan a través de iniciativas privadas en nuevos medios de comunicación, aparece entonces, el panorama de las libertades informativas.

Nace entonces el término Dircom, promovido por Entreprises et Médias, Asociación de los Dircom franceses (Costa, 2011: 92) Sin embargo, el reconocimiento como profesión se sitúa en el primer Congreso TOPCOM organizado en Francia en 1988. Entre los objetivos que se marcaron sus organizadores y participantes se encontraba realizar un documento que incluyera las funciones del profesional de la comunicación en las organizaciones (Morales-Lugo y Enrique, 2007: 84).

Aquí se presentaba al nuevo profesional como el nuevo director de comunicación global y entre algunas de sus funciones consta ser el responsable de coordinar la publicidad de productos y marcas, desarrollar las Relaciones Públicas, tener contacto con los medios de comunicación, la comunicación con los poderes públicos, bancos y universidades, el patrocinio, el mecenazgo, el marketing, la decoración interior, la elección de despachos (Morales-Lugo y Enrique, 2007: 84). No obstante, en los países europeos, la figura del Director de Comunicación se introdujo a mediados de la década de los noventa.

En 1992, otro evento que promovió la demanda de la formación universitaria es el Seminario de Cuenca, organizado por el Departamento de Comunicación Audiovisual y Publicidad (CAVP) de la Universidad Complutense de Madrid y el apoyo del Instituto de Investigación de la Comunicación de la Universidad Internacional Menéndez Pelayo y la colaboración de la revista Control. En el evento donde participaron directivos de empresas, comunicadores, periodistas y docentes llevó por temática "El Director de Comunicación”, y se dio mayor impulso y se definió de manera más perfilada la figura y el papel del Director de Comunicación. 
La realidad de América Latina no se aleja de la de Europa, donde el Dircom ha tenido su nacimiento y crecimiento de manera pausada. Joan Costa, de nacionalidad española, catedrático, sociólogo, investigador y consultor es el principal impulsor del Dircom en Latinoamérica.

El interés de la universidad también se ha visto reflejada en investigaciones y la creación y promoción de eventos académicos propios del Director de Comunicación.

A pesar de su gran crecimiento, el Dircom, sigue teniendo otras denominaciones, pero siempre se habla que su rol es gestionar una comunicación mucho más sólida al interior y hacia fuera de la organización y como un perfil que busca la difusión y visibilización del accionar de la organización para la gestión de los valores intangibles, de la imagen pública y la reputación institucional.

El Dircom es el responsable de la comunicación quien garantiza que toda la información que se genera al interior de la empresa y la que se transmitirá a sus públicos esté diseñada con estrategia y lleve siempre valores institucionales que harán a la comunicación diferente de la propuesta por otras empresas. El Dircom es el responsable de las estrategias y los procesos de comunicación institucional.

El Director de Comunicación es una figura clave dentro de la institución. Es el máximo responsable de la propuesta, ejecución, seguimiento y evaluación de la política de comunicación. Su principal función es ser guardián de la imagen institucional. Es el responsable de generar valor y crear cercanía entre la institución y los públicos.

El catedrático Villafañe para referirse a este profesional prefiere utilizar la palabra corporate como el responsable de la comunicación o la imagen de una organización (Villafañe, 1999: 11). El corporate es el profesional encargado de velar por el cuidado de los procesos de comunicación e imagen institucional con sus diferentes públicos a nivel interno y externo de la institución. 
En el Decálogo del Dircom de la Asociación de Directores Comunicación de España, (2017), manifiesta:

"El Director de Comunicación partiendo de los objetivos, visión, misión y valores de una organización, es quien asume la responsabilidad de definir y concretar la política de Comunicación Corporativa (...). Es también quién tiene que velar por el incremento del capital de activos intangibles: la notoriedad, la marca, la imagen y la reputación corporativas".

Maite Alba (Top Comunicación y RR.PP. 2013: 58), en un estudio sobre los Dircom del futuro y el futuro del Dircom, señala:

"El Dircom es la figura que ejerce (y ejercerá) el control sobre los nuevos canales online, (considerados actualmente) vehículos esenciales para la difusión de la marca y del proyecto empresarial no solo a nivel externo, sino también a nivel interno, involucrando y alineando a los profesionales de la compañía con la cultura corporativa y la estrategia de mercado".

El Dircom se ha convertido en un director de orquesta, que además de dirigir a su equipo de trabajo también compone y garantiza toda la gira de la que es responsable dentro de la organización. La exigencia moderna le obliga a ser un profesional lleno de creatividad, con dotes de estratega y mente abierta siempre al cambio y la transformación.

De acuerdo a los estudiosos Joan Costa (Costa, 2011) y Fernández (Fernández, 2011: 252) creen que el Dircom depende de la alta dirección de la institución y debe permanecer junto al máximo ejecutivo o director general. Además, Costa añade que debe ocupar un nivel horizontal, unida por nudos interrelacionados entre todos, se refiere a que el Dircom debe mantener contacto con todas las áreas de la institución y coordinar todos los procesos de comunicación.

En esta misma línea Joan Costa propone el esquema "de las tres esferas", que dan cuenta del accionar estratégico y operativo de cualquier empresa que permite una mayor conectividad y vinculación con los públicos, convirtiendo el organigrama clásico en un esquema 
de la acción comunicativa integrado, donde no existe jerarquía sino orden (Costa, 2011: 105)

- La comunicación institucional está relacionada a través del Dircom con el máximo responsable de la empresa y con quienes tienen poder de decisión dentro del organigrama institucional.

- La comunicación mercadológica se vincula en colaborar en todo el proceso de campañas y productos comunicacionales que se generan desde el área de marketing y afecten con la identidad visual de la institución.

- La comunicación organizacional se vincula de manera directa con la cultura comunicacional interna, desde la Dirección de Comunicación junto a Recursos Humanos se investiga cambios culturales y se elaboran planes de comunicación internos.

Es innegable, la evolución que ha tenido el Dircom, donde asume nuevos roles y retos profesionales alineados a la misma comunicación. Al cambiar su denominación a Marcom, se produce una integración del marketing y la comunicación.

Los estudiosos Westphalen y Piñuel (1993: 822-823) a través de Ana Almansa expresan que es el responsable encargado de la comunicación publicitaria y de la no publicitaria. En algunas instituciones se encuentra integrado en el departamento de marketing y en otras, directamente vinculado a la dirección general de la empresa o a su presidencia (Almansa, 2004: 52).

Paralelo a ello, las estructuras han ido cambiando constantemente, han pasado de ser sencillas oficinas que atendían únicamente temas de relaciones públicas, hasta los actuales y bien estructurados departamentos de comunicación y marketing (que atienden acciones de publicidad, mercadeo y relaciones públicas), producto del crecimiento tecnológico y de las nuevas formas de comunicación implementadas por profesionales de comunicación y también, exigidas por los diversos públicos que demandan de una comunicación más directa y real. 
El profesional que cumpla el rol de Marcom dentro de la organización debe poseer un alto nivel de formación profesional, sus competencias deben estar en la vanguardia de las exigencias de la modernidad. Debe planificar la comunicación de la organización de manera integral, partiendo de los objetivos, visión, misión y valores de la institución.

Este profesional asume la responsabilidad de integrar la comunicación institucional y la comunicación mercadológica bajo una misma línea comunicacional. Sus conocimientos y habilidades profesionales deben permitirle encontrar las estrategias de comunicación efectivas para conectar las necesidades de las audiencias con la empresa.

El Marcom debe garantizar a nivel interno un buen equipo de trabajo y la calidad de servicios y productos que estos ofrezcan a los miembros de la organización y a otros públicos a los que se dirige.

Las exigencias modernas le obligan a ser un profesional en busca de la integralidad de la comunicación.

A través de la comunicación se deben gestionar productos de valor e interés y buscar canales de comunicación basados en las preferencias de los públicos. Desde la óptica del marketing se debe hacer que esos contenidos se conviertan en potencialidades para atraer más clientes. Esa conjugación de trabajo se logra con la puesta en marcha del Marcom.

Al referirse a la generación de contenido en el libro blanco de Dircom, se propone una evolución del actual Director de ComunicaciónDircom a Director de Contenidos-Dircon, lo cual para muchos pensadores es lógico y razonable (Kantar, 2013: 4). En este documento se expresa que esta evolución supone que el profesional debe cuidar la comunicación tradicional y la digital. Donde la generación y difusión de contenido se ha convertido en la clave para conectar la organización con los públicos.

Quien se desempeñe como Marcom debe tener una formación integral. Su perfil profesional y académico debe ir acompañado de una continua autoformación. Al igual que el Dircom debe poseer un espíritu crítico, 
tener una actitud positiva, receptiva y abierta, disposición fresca, analítico y calculador, saber evaluar con rigor las ideas, situaciones y decisiones institucionales, imaginativo, buscar nuevas relaciones estratégicas, enfocar las cosas desde una perspectiva no tradicional.

Actualmente muchas organizaciones coordinan la comunicación desde áreas diferentes, por un lado, la comunicación publicitaria y por otro la no publicitaria, haciendo en algunos casos que los mensajes y los recursos se dupliquen y en otros se llegue a confundir al público. Por lo tanto, lo que persigue el Marcom, es integrar en su totalidad el área de comunicación y que este a su vez trabaje de manera coordinada con todas las áreas que componen el equipo de comunicación. Así mismo, este coordinará con la máxima autoridad la política de comunicación de la institución.

Por otra parte, y como se ha mencionado anteriormente, el trabajo del Marcom debe estar basado en la planificación, pero también deben medirse todos los resultados e impactos de las estrategias que se plantee, que incluirán temas publicitarios y comunicacionales.

En la realidad actual, la tendencia de la comunicación apunta hacia herramientas digitales y comunicación online; por ello, es fundamental que el Marcom esté preparado y siempre alerta a todos los cambios, pero especialmente dispuesto a adaptarse a los procesos de metamorfosis que la sociedad moderna los exige. Incluso en la misma propuesta de terminologías vemos como algunos elementos afirman este planteamiento.

Para el Marcom los públicos seguirán siendo el eje transversal a su gestión y los más importantes al momento de investigar, planificar, comunicar y evaluar la comunicación. Las organizaciones siguen girando en torno a los públicos de su interés.

Para las profesoras Valdiviezo, C. y Valarezo, K. (2015: 102), el Marcom debe garantizar a nivel interno un buen equipo de trabajo y luego eso se verá reflejado en la calidad de servicios. Acompañado también, que desde la alta gerencia se deben establecer políticas en beneficios de los stakeholders internos. 
El Marcom debe poseer una visión de estratega y debe utilizar el buen juicio para la toma de decisiones oportunas a nivel institucional tanto con la comunicación tradicional y la comunicación digital. Debe ser un profesional moderno, que investiga lo que pasa en el mundo para luego conectar las necesidades de los públicos con la organización a través de estrategias de comunicación efectivas. La clave de este profesional está en aprender constantemente, reciclarse y volver aprender para no morir.

En esta gestión son los claves los stakeholders, por lo que miraremos también una evolución de ellos entorno a las nuevas tecnolgías y como inciden en la construcción de marca de las organizaciones con impactos a nivel internos y externos.

\section{Los públicos, frente a la nueva realidad corporativa}

La disrupción del entorno al que años atrás se enfrentaban las organizaciones, es sin duda producto del surgimiento en alza de las Tecnologías de la Comunicación e Información que han cambiado la forma de ver el mundo.

Hoy no existe las barreras de tiempo ni espacio para comunicarse a cualquier parte del mundo, esto ha provocado cambios de comportamiento significativos en los stakeholders y en el mercado al que se enfrentan las organizaciones, especialmente caracterizado por la hipercompetencia.

"La evolución de una sociedad industrial a una sociedad del conocimiento en la que el consumidor tiene cada vez más contacto con las empresas y donde estas se centran en los aspectos intangibles para diferenciarse ha provocado que la "empresa" pase a ocupar un segundo plano, y que la "persona" se convierta en el verdadero protagonista de la organización. Esta nueva realidad convierte al empleado en uno de los protagonistas de la creación de marca" (Aguerrebere, 2013: 45). 
Así nace la nueva realidad corporativa que no es más que la "construcción colectiva que define el espacio cotidiano de la organización” (Manucci, 2007: 17).

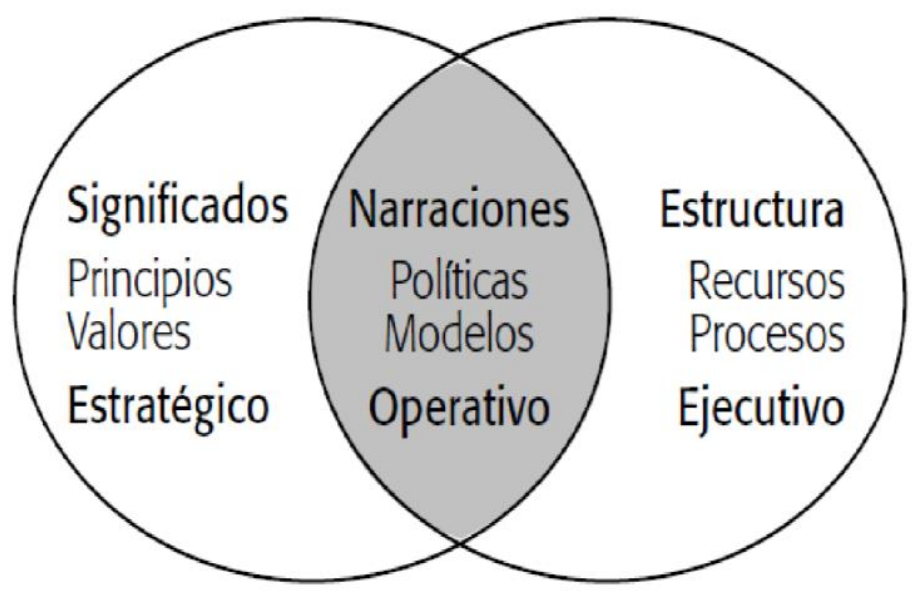

Figura 2. Estructura de las tres dimensiones interdependientes de la realidad corporativa. Fuente: Manucci (2007: 17)

Tal como se muestra en la figura 2, Marcelo Manucci propone una estructura básica de las tres dimensiones interdependientes de la realidad corporativa. Así explica que el presente corporativo surge como un espacio conformado por:

- Las definiciones establecidas que circulan en la organización.

- Los significados representativos de la realidad corporativa.

- Los ejes de orientación estratégica de esos significados.

Es decir, que la organización construye su propia versión del contexto a partir de su visión subjetiva de los acontecimientos cotidianos del entorno. Por ello, uno de los grandes retos de la empresa actual es prepararse para lo desconocido, para los desafíos permanentes que la dinámica social exige.

Quizá uno de los desafíos más importantes de las organizaciones es la diversidad de públicos internos y externos cambiantes, inestables, exigentes, inclusivos, etc., a los que deben dar respuesta. 


\section{La comunicación y los públicos como gestores de marca.}

La gestión estratégica de comunicación de marca está íntimamente ligada a la gestión de los públicos en todas sus dimensiones. La relación que establecen los stakeholders con la organización, genera experiencias positivas o negativas que son el punto de partida para la creación de una imagen temporal y a largo plazo de la reputación.

Guillermo Bosovsky, director de la empresa Investigación de Públicos de marketing, comunicación e innovación, Doxa, señala que "la marca es el punto de encuentro entre la identidad y la imagen de una empresa. Es el resultado de la confluencia entre la voluntad de los gestores y la percepción de los públicos".

Por tanto, el accionar de comunicación deberá responder a las necesidades y motivaciones de los públicos, a la construcción y generación de una experiencia única, a la medida de cada stakeholder, basada en la filosofía ganar - ganar.

En este sentido, uno de los factores claves en comunicación es la escucha activa, más aún cuando se trata de la gestión de públicos, así Bosovsky, en su blog empresarial destaca la importancia de esta acción como parte del trabajo al interno de la organización: "escuchar a los públicos es más que preguntarles lo que piensan mediante una encuesta, o unos focus groups, o leer lo que dicen en las redes sociales. Es producir insights e inteligencia estratégica, aprovechando su experiencia y su inteligencia".

Es así, que gran parte del éxito de la gestión de marca, se basa en visibilizar hacia los públicos una sólida cultura e identidad corporativa, es decir, "ser y parecer". Lograr que los públicos se identifiquen con la organización implica entonces, integran un valor agregado en su relación.

Sin embargo, una de las mayores preocupaciones en Latinoamérica en el ámbito de la comunicación es que aún se evidencia una resistencia en la gestión efectiva de los públicos, sin tomar en cuenta que: 
"Lo más interesante es que el usuario y el ciudadano comienzan a valorar el trato personalizado y exigen esa actitud a las empresas y a la administración pública. Pero lejos de ser una práctica habitual, empresas y gestores públicos aún se mueven con lógicas analógicas de comunicación broadcast. La segmentación, la personalización y la transparencia en la comunicación con clientes y ciudadanos aún resultan un tanto utópicas" (Pardo, 2014: 145).

Frente a ello se debe reiterar que la gestión de los grupos de interés es el eje central de cualquier estrategia empresarial, esto implica que alinear la estrategia con las expectativas de la sociedad generará un vínculo que puede constituirse en una ventaja competitiva. Más aún cuando hablamos de los públicos internos que son los representantes de la identidad y cultura empresarial frente a los stakeholders externos.

\section{Tendencias de la comunicación interna}

Las empresas de hoy tienen claro que la comunicación es uno de los ejes fundamentales de su desarrollo. En palabras de Joan Costa, la gestión de la comunicación es "el sistema nervioso central de las organizaciones". Sin embargo, dichas empresas, a lo largo de la historia, han centrado sus esfuerzos en la comunicación institucional y mercadológica, que están dirigidas hacia los públicos externos, y específicamente al stakeholder cliente. Es decir, que la Comunicación Interna - se ha rezagado por muchos años a un papel secundario. Pero el contexto actual en el que se desenvuelven las organizaciones, caracterizado por la hipertransparencia, la credibilidad, la Responsabilidad Social Empresarial y la importancia de la reputación corporativa, la práctica de la Comunicación Interna toma auge y empieza a ser explorado y valorado en las organizaciones.

Si bien en la última década se intensifica el interés profesional e investigativo por la Comunicación Interna, esta arista de comunicación siempre fue importante y necesaria en la gestión efectiva de la comunicación en la organización. El Dircom, la ha abordado desde diferentes perspectivas, tal como se señaló en los apartados anteriores. 
"Solo las compañías líderes que asumen que la auténtica comunicación engloba el conjunto de las actividades de una organización encaminadas hacia la obtención del éxito empresarial, traducido éste en beneficios económicos y desarrollo comunitario, conceden a la comunicación interna el papel estelar que debe tener en la gestión del negocio" (Álvarez, 2018: 1).

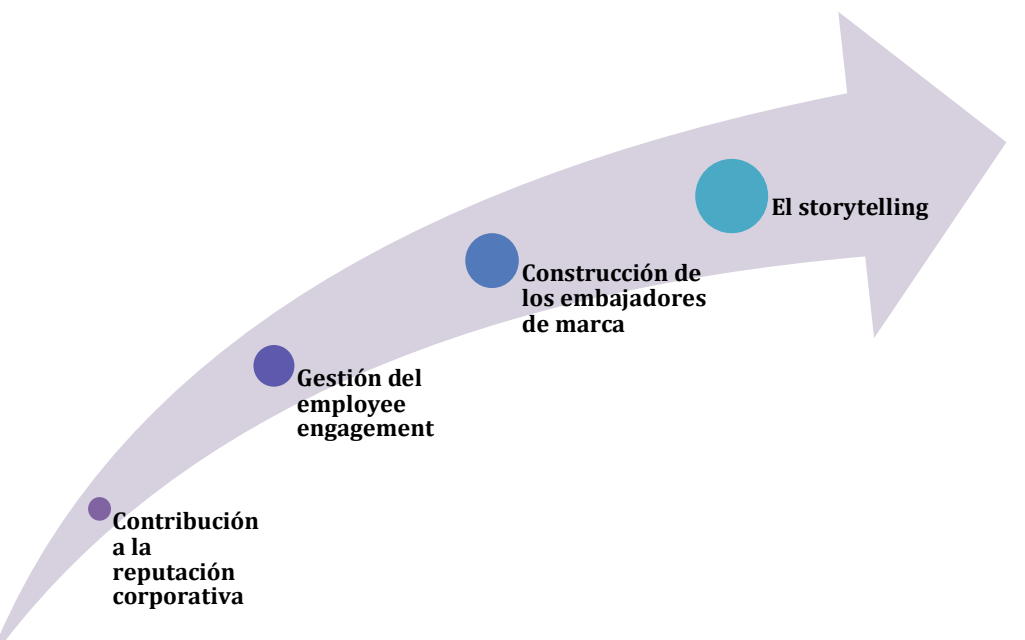

Figura 3. La comunicación interna como prioridad de las tres esferas de la comunicación. Elaboración propia.

El empleado o colaborador, es el eje central del accionar de la Comunicación Interna, pues su papel en la institución es determinante en el éxito y sostenibilidad de la misma.

"Los nuevos empleados quieren tener un contacto de más calidad, más abierto y bidireccional. No extraña, por lo tanto, que una de las habilidades que más preocupe a los directivos, junto a los idiomas y el dominio de las TIC (Tecnologías de la Información y la Comunicación), sea la de transmitir correctamente las líneas de acción" (Álvarez, 2018: 3).

El presente corporativo que hoy afrontan las organizaciones, ha provocado el nacimiento e incorporación de nuevas tendencias de 
comunicación, dirigidas en especial al público interno, los colaboradores.

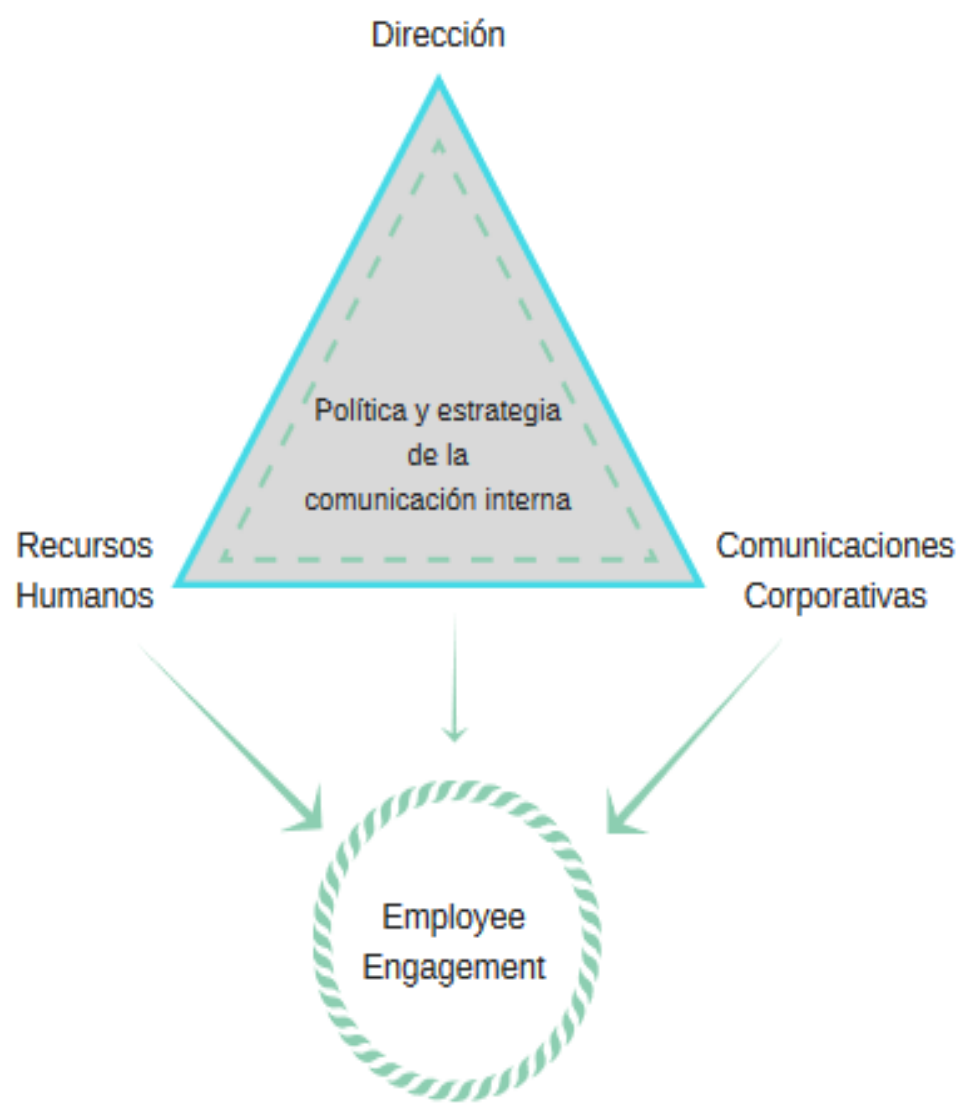

Figura 4. Responsabilidad en la gestión del employee engagement. Fuente: Ritterm 2012:7. Elaboración propia.

A continuación, se detallan cinco de las más destacadas.

- Contribución a la reputación corporativa, la reputación desde siempre se ha constituido en el activo intangible más valorado por la organización. El cumplimiento de promesas en los colaboradores es uno de los requisitos básicos para la generación de los atributos claves de la reputación: la credibilidad y confianza. Articular una relación positiva, basada en estos dos atributos, permitirá a los colaboradores transmitir sus experiencias a los consumidores a través de diferentes canales, el face to face, los medios sociales, entre otros.

- Gestión del employee engagement, es uno de los principales desafíos que hoy enfrentan las organizaciones, y en muchos casos se le delega esta responsabilidad al departamento de Recursos 
Humanos, sin embargo, ya se ha empezado a hablar de una responsabilidad compartida bajo la trilogía de la responsabilidad de la comunicación interna. La gestión del compromiso del colaborador está basada en la relación empresa - empleado, caracterizada por talento humano más crítico, exigente, indiferente a los métodos tradicionales, que busca un valor agregado en su estancia en la compañía. Cuidar los factores que influyen en el ambiente laboral y que pueden repercutir en la gestión del compromiso empresarial debe ser una prioridad, pues de acuerdo a diversas investigaciones se ha demostrado que las problemáticas existentes al interior de la organización repercuten en la actitud del empleado hacia su propio trabajo y hacia la empresa, lo que disminuye en su grado de integración, motivación y productividad.

- Construcción de los embajadores de marca, en el marco de la evolución de la dinámica social, la realidad empresarial es que los talentos ya no buscan a las empresas, sino que las empresas los buscan a ellos. Esto ha conllevado a las organizaciones a trabajar estratégicamente en la generación de compromiso en sus colaboradores, la idea es fomentar la identificación con la marca, valores, cultura e historia de la organización, para que los trabajadores se conviertan en embajadores de marca en todos los niveles, a esto se lo denomina como employer branding, definido específicamente como la "aplicación del marketing a nivel interno pero con impacto tanto interno, para incrementar el orgullo de los actuales empleados, como externo, en el mercado laboral para atraer a los potenciales trabajadores talentosos" (Gómez, 2011: 5).

- El storytelling, contar historias permite conectar con el público, genera un vínculo emocional, una identificación con la persona y la organización, por eso es una de las tendencias más recurrentes de los últimos tiempos, los públicos de hoy confían en las recomendaciones de otros públicos, para tomar decisiones.

\section{El nuevo perfil de los colaboradores}

Para poder gestionar efectivamente la Comunicació Interna es necesario conocer quién es nuestro público. En 2018 en Latinoamérica 
las organizaciones cuentan, mayoritariamente con tres clases de colaboradores: los Baby Boomers, la generación X y los millenials, sin embargo, empiezan ya a insertarse la generación $\mathrm{Z}$ o posmillenials a su vida laboral.

Uno de los factores que como gestores de comunicación deberíamos tener en cuenta son: el estilo de vida y las metas y/o anhelos de nuestros colaboradores.

De acuerdo al Estudio Global Nielsen sobre los Estilos de Vida Generacionales (The Nielsen Global Generational Lifestyles Survey), en donde se encuestó a 30,000 participantes de 60 países pertenecientes a América, Europa, Asía y África, se evidenció factores en los que las organizaciones deben poner énfasis.

Una de las temáticas de mayor interés para las organizaciones, respecto al estudio mencionado, es el nivel de satisfacción laboral, que muestra que más de la mitad de las generaciones Millenial, generación X y Baby Boomers están satisfechos con sus ocupaciones, ambiente laboral, colegas, balance trabajo/vida y jefes y este sentimiento se acrecienta con la edad. Sin embargo, menos de la mitad está satisfecho con su ingreso y otros beneficios y el sentimiento decae también, conforme avanza la edad.

No obstante, que estas generaciones estén satisfechas con sus empleos no implica que sean fieles a las organizaciones. El mismo estudio señala que en comparación con los miembros de la generación $\mathrm{X}$ y Baby Boomers, los Millennials son casi dos veces más propensos a dejar un trabajo después de dos años, 1.5 veces más después de cinco años y la mitad a permanecer en el mismo después de 10 años.

Este dato es corroborado por estudio de Deloitte, en donde se señala que $87 \%$ de sobre 3.000 líderes de Recursos Humanos y de negocio, en 106 países, califica el bajo compromiso de los colaboradores como su principal problema, frente a $79 \%$ en la edición anterior.

Por otro lado, el $56 \%$ de los empleados quieren cambiar de empleo por una causa relacionada con su motivación y alineación con los objetivos empresariales, mientras que sólo el 18\% lo haría por lograr una mejora 
económica, de acuerdo al Informe especial Employee Engagement: la asignatura pendiente, de Llorente\&Cuenca 2015.

Otro factor preponderante en esta temática es la influencia del líder en los colaboradores, según lo expuesto en los 10 Shocking Statistics About Disengaged Employees, el 75\% de los trabajadores no dejan su trabajo sino a su jefe, es decir que en los directivos recae gran parte de la responsabilidad de la permanencia y gestión del compromiso de los empleados de la organización.

Con las estadísticas expuestas en este apartado se puede evidenciar que el trabajo de las organizaciones en cuanto a la gestión de compromiso desde el accionar de la comunicación interna apenas ha iniciado y por tanto queda mucho camino por recorrer.

\section{E1 Dircom, como gestor de talento humano}

La gestión del talento humano en el panorama actual ha evolucionado, provocando que se integren algunas estancias de la organización para su efectiva labor. El reto de las empresas, en esta época en la que se está replanteando el liderazgo empresarial demanda de un nuevo tipo de gestión, basado en competencias comunicacionales, la capacidad de escucha, la confianza, transparencia de información, el status, etc., exigencias que ya no solo deben trabajarse desde el Departamento de Recursos Humanos, sino que necesita la intervención del Dircom y el $\mathrm{CEO}$, como representante de la cultura, imagen y reputación de la corporativa.

En los apartados anteriores se destacó brevemente las responsabilidades del Dircom, vinculadas gran parte a la Comunicación Interna a las que este profesional dedica aproximadamente el $80 \%$ de su tiempo.

En el ámbito corporativo las dos responsabilidades íntimamente ligadas a la gestión de públicos, de acuerdo al listado propuesto por Costa (2012) son: 
- El Dircom asume las relaciones institucionales al más alto nivel de los stakeholders: accionista, asuntos públicos e internacionales, líderes de opinión, medios de comunicación, etc.

- Estratega gestor de activos intangibles, es responsable de la imagen pública, el posicionamiento y la reputación corporativa.

Así en Costa (2015:77) al hablar del Sistema Dircom, se destaca que el objeto de la función de consultoría interna es "contribuir a la toma de decisiones estratégicas y asegurar la coherencia de los objetivos y su ejecución con las líneas maestras de la Identidad y Cultura corporativa e institucional junto con los valores intangibles que singularizan a la organización".

Esto da la pauta de cómo, entre su labor, el Dircom deberá vincularse como gestor de talento humano, pues a nivel interno será el "el abogado de los públicos ante la empresa, a la que trasladará las voces, las expectativas de los públicos estratégicos y las oportunidades" (Costa, 2012: 88-89). Es decir, que será el representante de los colaboradores, el que permitirá generar un diálogo entre la alta dirección y el equipo humano de la empresa.

Así también, entre su rol como estratega generalista y polivalente, el Dircom debe ser el "animador de grupos de trabajo entre los que introducirá la didáctica de la comunicación y la cultura de cooperación transdisciplinar" (Costa, 2012: 88).

Esto permite visibilizar que la gestión del talento humano residirá como parte de la Comunicación Interna al impulsar la toma de decisiones estratégicas, transversales, que aporten al impulso y mejoramiento de la calidad y/o experiencia de vida en el trabajo de los colaboradores. En este sentido, se debe partir de los elementos que influyen en la experiencia laborar del empleado que pueden favorecer la integración, motivación y engagement de los equipos de trabajo.

\section{Gestión del compromiso de los colaboradores}

El employee engagement o gestión del compromiso es una de las tendencias en alza, que mayor aporte entrega a la organización, sobre todo en lo 
que se refiere a cumplimiento de objetivos. Está estrechamente relacionada en employer branding.

"Cada persona empleada en la empresa es un vehículo publicitario y auto-propagandístico de dentro hacía fuera de la propia empresa, es decir, "vende" imagen empresarial" (Barquero y Barquero, 2002: 37). De ahí la importancia de potenciar el sentido de pertenencia y el compromiso del empleado hacía la institución. Que la organización sea admirada por sus públicos, no solo depende de la comunicación, sino en gran parte lo determinarán los valores que se profesan al interior de la empresa, es decir su cultura, pues debe tenerse claro que la reputación se constituye en un trabajo colectivo a largo plazo que será un reflejo de la cultura organizacional, manifestada en forma de actitudes y conductas de nuestros colaboradores (públicos internos) y que a través del tiempo se manifestaran en la percepción de terceros (públicos externos) hacia la organización. (Duque, 2017: 60)

Aquí nace el interés por el denominado público interno y su respectiva gestión en pro de los intereses de la organización. Robles (2001: 9) explica que "la integración y motivación del denominado trabajador (...) se ha convertido en una verdadera prioridad para las grandes empresas, conscientes de que la inteligencia y el talento personal de sus empleados es la única materia prima que puede diferenciarlas de la competencia". Esta afirmación, ratifica que el compromiso de los colaboradores es la clave para alcanzar un nivel superior de competitividad ante el mercado cambiante e inestable que enfrentan las empresas. Fidelizar al talento humano de la compañía otorga múltiples beneficios, pues la filosofía de su gestión debe estar basada en el principio ganar-ganar. Entre los principales beneficios del employee engagement para la organización se puede destacar:

- Aumento de productividad de los colaboradores.

- Mejora del nivel de satisfacción e involucramiento del colaborador.

- Eficiencia de trabajo.

- Cohesión de los equipos de trabajo.

- Menor rotación de personal.

- Ahorro de recursos económicos, mayor rentabilidad. 
Sin embargo, para alcanzar estos beneficios, la gestión del compromiso del empleado requiere algunos requisitos básicos, que son de gran importancia, entre los que sobresalen:

- Un adecuado clima laboral y beneficios sociales.

- Proyección profesional.

- Actuación de competencia y conocimientos permanentes.

- Salario justo.

- Reconocimiemto.

- Liderazgo.

La base de todos estos requerimientos, es la toma de conciencia de los públicos de la necesidad de contar con un ambiente de trabajo que contribuya a su felicidad.

Otro elemento relevante de este proceso es también, sentirse parte importante de la organización con la que comparten parte de su vida, es decir, estar al tanto de las decisiones que los altos mandos toman respecto al camino a seguir. "Una verdad a medias no deja de ser cierta, pero es insuficiente para transmitir la realidad" (Ritter, 2012: 12). Es por esta razón que debe crearse flujos de comunicación que permitan mantener adecuadamente informados a los colaboradores en todos los niveles institucionales, consolidando así el compromiso y la satisfacción del talento humanos de la organización.

\section{Referencias}

Aguerrebere, P. (2013). Marca y comunicación empresarial. Barcelona: Editorial UOC.

Almansa, A. (2004). Teoría, estructura y funcionamiento de los gabinetes de comunicación. El caso andaluz. Málaga: Universidad de Málaga, Asociación Americana de Agencias de Publicidad. (2018) ¿Para qué sirve la Comunicación Integrada de Mercadotecnia? Recuperado de: https://cambiomkt.wordpress.com/2017/06/12/para-que-sirve-lacomunicacion-integrada-de-mercadotecnia/

Álvarez, J. (2018). Comunicación Interna, la Estrategia del Éxito. Razón y Palabra [en línea] 12 (abril-mayo). Recuperado de: http://www.redalyc.org/articulo.oa?id=199520729023 
Barquero, J. y Barquero, M. (2002). El libro de oro de las Relaciones Públicas. España: Gestión 2000 S.A.

Benavides, J., y Villafañe, J. (2001). Dirección de comunicación empresarial e institucional. Barcelona: Gestión 2000.

Costa, J. (2011). El ADN del dircom (19. ed.). Barcelona: Granollers.

Costa, J. (2012). El DirCom de boy. Dirección y Gestión de la Comunicación en la nueva Economía. Barcelona: Costa Punto Com.

Costa, J. (2015). El paradigma DirCom. El nuevo mapa del mundo de la comunicación y el management estratégico global. Barcelona: Costa Punto Com.

Deloitte Insights. (2017). Global Human Capital Trends. Recuperado de: https://www2.deloitte.com/insights/us/en/focus/human-capitaltrends $/ 2017 . \mathrm{html}$

DIRCOM. (2014). Asociación de directores de comunicación en España. Recuperado de http://www.dircom.org/sobre-dircom/que-esdircom

Duque, V. (2017). Gestionar de la Reputación, el valor agregado de la comunicación estratégica. Revista Encontexto, (87), 59-60.

Fernández Fernández, M. (2011). Comunicación y reputación en empresas e instituciones: Experiencias profesionales y propuestas prácticas. Madrid: Universitas.

Gómez, C. (2011). Employer branding. Bogotá: Colegio de Estudios Superiores de Administración. Recuperado de: http://repository.cesa.edu.co/bitstream/handle/10726/277/BI44.p df? sequence $=6$

Llorente \& Cuenca. (2015). Employee Engagement: la asignatura pendiente. Informe especial. Recuperado de: http://www.desarrollandoideas.com/wp-

content/uploads/sites/5/2015/06/150618 informe especial DI e mployee engagement ESP.pdf

Losada, C. (2002). Prensa e imagen corporativa en la universidad: Los públicos internos (1a. ed.). Murcia: Universidad Católica San Antonio.

Manucci, M. (2007). Comunicación estratégica. Prepararse para lo desconocido: cómo desplegar el futuro cambiando el presente. Siglo y Pensamiento 51 volumen XXVI. Recuperado de:

http://www.scielo.org.co/pdf/signo/n51/n51a03.pdf

Morales-Lugo, F., y Enrique, A. M. (2007). La figura del "dircom". Su importancia en el modelo de comunicación integral. Anàlisi:

Quaderns De Comunicació i Cultura, (35), 83-93.

Nielsen. (2015). El Estudio Global Nielsen sobre los Estilos de Vida Generacionales. Recuperado de: 
https://www.nielsen.com/content/dam/nielsenglobal/latam/docs Lreports/2016/EstilosdeVidaGeneracionales.pdf

Pardo, H. (2014). Opportunity Valley. Lecciones <aún> no aprendidas de treinta años de contracultura digital. Barcelona: Outliers School.

Barcelona.Top Comunicación y RR.PP. (2013). El dircom del futuro y el futuro del dircom. (No. 1). En línea http://burson-marsteller.es/wpcontent/uploads/2013/03/Informe-Futuro-Dircom.pdf

Raúl Sarasola. (2018). Pastillas de Marketing y Comunicación. Recuperado de: http://raulsarasola.blogspot.com/2010/09/que-son-lascomunicaciones-integradas.html

Ritter, M. (2012). Cultura organizacional. Buenos Aires: La Crujía Ediciones. Robins, A. (2017). 10 Shocking Statistics About Disengaged Employees.

Recuperado de: https://www.officevibe.com/blog/disengagedemployees-infographic

Robles, M. (2001). La comunicación interna en las entidades financieras andaluzas. El ejemplo de El Monte y CajaSur (tesina). Facultad de Comunicación, Sevilla.

Valarezo, K., Valdiviezo, C. y Córdova, J. (2015). El rol estratégico de la Dirección de Comunicación en la Gestión de las Organizaciones. Revista ESPACIOS| Vol. 36 (No 13) Año 2015.

Valdiviezo, C. y Valarezo, K. (2015): "Del Dircom al Marcom, un proceso de evolución de la comunicación" en Comunicar desde las organizaciones: Tendencias, estrategias y casos (Miguel Túñez López y Verónica Altamirano, Coord.). Cuadernos Artesanos de Comunicación, 96. La Laguna (Tenerife): Latina.

Villafañe, J. (1999). La gestión profesional de la imagen corporativa. Madrid: Pirámide. 


\title{
A Gestão das organizações emergentes: o impacto das redes sociais online nas Startups
}

\author{
Paula Cristina Ribeiro de Oliveira \\ Universidade de Santiago de Compostela
}

PARA CITAR: Ribeiro de Oliveira, P. (2018). A Gestão das organizações emergentes: o impacto das redes sociais online nas Startups. En Túñez-López, M., Costa-Sánchez, C. y Valdiviezo, C. (Eds.), (2018). Comunicación Organizacional en entornos online. Gestión, actores y recursos. Cuadernos Artesanos de Comunicación, no 149 (pp. 157-181). La Laguna (Tenerife): Latina.

\section{Resumen}

No atual contexto de mercado, a comunicação tornou-se um recurso estratégico para qualquer empresa. Ao contrário da maioria dos mass media, o web marketing proporciona uma oportunidade menos dispendiosa, imediata e mais transparente de promover negócios numa comunidade global. Atualmente, as redes sociais online vieram mudar a relação dos utilizadores não só com a Internet, mas também com as empresas. As startups têm uma relação ímpar com as redes sociais, esta realidade permitiu dar um salto quantitativo e qualitativo nas suas estratégias, assiste-se agora a uma nova forma de desenhar a comunicação. Uma panóplia de startups surge para explorar o potencial destas redes, acreditando que demarcando uma posição ativa, podem alcançar o sucesso com a aproximação ao cliente, trata-se, de uma ferramenta incontestável ao serviço das empresas.

Palabras clave: comunicação, redes sociais, startup, lean startup, lean branding. 
A tecnologia da informação tem provocado profundas mudanças em todo o mundo. Essas mudanças levaram ao crescimento e popularização da Internet. Mais da metade da população mundial já conta com acesso à Internet, aponta o último relatório Digital in 2018, divulgado pelos serviços online Hootsuite e We Are Social.

De acordo com as duas companhias, somos mais de 4 bilhões de pessoas conectadas à rede, enquanto as estimativas mais recentes apontam para uma população global de 7,6 bilhões de seres humanos. Falando em números específicos, o ano de 2018 iniciou com 4,021 bilhões de pessoas online ( $53 \%$ de todas as pessoas do planeta), um aumento de $7 \%$ em relação ao ano anterior. As redes sociais são utilizadas por cerca de 3,2 bilhões de pessoas ( $42 \%$ de todo o mundo).

Nesta perspetiva de avanços tecnológicos e com os mercados abertos, o desenvolvimento das tecnologias de informação e comunicação abriu o mundo para qualquer organização.

Esta conjuntura de avanços fez com que novos serviços surgissem através da Internet, desenvolvendo novas formas de comunicação. Entre eles destaca-se a difusão de redes sociais digitais, ambientes virtuais interativos onde os usuários trocam informações, contatos, experiências e opiniões. Reconhecendo esta tendência, e motivados pela rapidez, facilidade, abrangência, baixo custo e o alto nível de interatividade, as empresas começaram a aderir a sites e publicações nas redes sociais digitais, procurando aproximar-se dos seus clientes para gerar vendas e lucro. Assim, grande parte das empresas passaram a utilizar as redes sociais como ferramenta de comunicação com clientes.

As empresas têm que chegar até aos seus clientes de forma eficaz, devem fazê-lo através dos media que os clientes usam ativamente. Não obstante, as startups, conhecidas pela sua criatividade, dinamismo e inovação aliaram-se aos medias digitais para promoção dos seus negócios. Fomentadas pela necessidade, pela pro-atividade e pela luta pessoal por melhores condições de trabalho e de vida, a criação do próprio negócio e a abertura de novas empresas constituem um cenário 
cada vez mais frequente. Neste âmbito, o conceito de startup ganhou força e forma, tornando-se incontornável no mercado.

A crescente importância que vem sendo atribuída à comunicação no seio das empresas, porque ajuda na apresentação da empresa ao mercado, divulgação de produtos/serviços, a angariação de clientes, alcance e manutenção de uma posição competitiva, dependem claramente de uma estratégia de comunicação bem definida.

Deste modo, a consciência do peso que esta área representa, especialmente numa startup é cada vez maior. Como principal forma de comunicar a marca, o destaque é dado à comunicação online que apresenta novos formatos de comunicação que se pautam pela transparência, criação de comunidades, efeito viral, passagem do discurso ao diálogo, da informação à participação. A comunicação online satisfaz necessidades de rapidez e baixo custo, alcance geral e forte impacto.

O presente capítulo visa compreender a realidade deste tipo de empresas numa vertente ainda pouco explorada, a vertente comunicacional. Mais concretamente como definem as suas marcas, as marcas Lean, e como as ativam através da politica de comunicação, perceber também a sua visibilidade nas redes sociais.

Torna-se importante compreender as mudanças que estão a ocorrer na gestão da comunicação nestas empresas emergentes e na gestão das relações com os públicos, devido exclusivamente à Internet como espaço de interação social.

Antes de passar ao cerne da questão, que é o que atrás ficou explanado, entende-se oportuno iniciar-se pela contextualização e explicação do conceito Startup, Lean Startup que é um novo movimento iniciado por Steve Blank, e a metodologia Lean branding.

O último analisa a resposta ao atual contexto social, económico e tecnológico marcado pela rapidez, complexidade e vulnerabilidade, exigindo um diálogo perante com os clientes, não só na venda, como também e sobretudo, na criação e valor e comunicação da marca. 


\section{Startup: Definição Conceptual}

Fatores como a situação económica dos países, o desemprego que em alguns casos chega a atingir números preocupantes, o apoio ao empreendedorismo pelos Governos da República com sistemas de incentivo, despoletaram um enorme interesse em torno do conceito de empreendedorismo e consequentemente na criação de startups.

Eric Shmidt, ex-CEO da Google, afirmou em 2010 que em dois dias era criada a mesma quantidade de informação que a humanidade criou, desde o seu nascimento, até 2003.

Esta velocidade requer uma habilidade de adaptação das organizações, que precisam sustentar os seus modelos de negócios através de inovações não apenas coerentes, mas que também façam o uso das novas tecnologias vigentes. Desta forma, houve nas últimas décadas uma aceleração do ritmo de crescimento de algumas empresas como nunca antes fora visto, sobretudo devido às novas possibilidades de modelos digitais possibilitadas pela Internet.

Com estas novas opções, as startups, chamaram a atenção dos investidores devido ao possível retorno num curto período de tempo, consolidaram a fama de Silicon Valley e vêm-se espalhadas um pouco por todo o mundo.

O termo startup não é assim tão recente e já tinha sido amplamente citado por autores economistas desde o início do século XVII. No entanto, Gitahy (2010) afirma que foi nas últimas décadas que ele ganhou uma nova forma com a chegada da "bolha da Internet", entre 1996 e 2001 e onde nasceu o conceito empresarial estadunidense de startup. Usado nos Estados Unidos há algumas décadas, foi só a partir da difusão das empresas "ponto com" que o termo foi ganhando novos contornos e se estabelecendo como uma nova abordagem empresarial.

As startups são por norma empresas relativamente novas, que têm como base ideias inovadoras e tecnológicas, tendo no seu início custos de manutenção reduzidos e sendo profundamente escaláveis quando o projeto é de sucesso, conseguindo aumentar os seus lucros 
rapidamente. Para alcançar um maior êxito, entende-se que os empreendedores das startups deverão desenvolver competências de forma a reagir facilmente à mudança e adquirir uma equipa multidisciplinar. Pode-se dizer, portanto, que as startups nascem de ideias de empreendedores (Toledo, 2012) num contexto criativo e inovador, tendo por objetivo solucionar um problema, utilizando um modelo de negócio que seja rentável e escalável, e em condições de extrema incerteza (Blank y Ries, 2012).

Esta condição de incerteza é comum em ambientes de alta tecnologia, principalmente devido à concorrência e mudança frequente de tecnologia, tornando constante o desenvolvimento de novos produtos neste tipo de empreendimento. As startups são mais recetivas à inovação e às novas tecnologias, assim como mais recetivas à mudança e à adoção dos social media.

Repetível quer dizer que pode entregar o mesmo produto em escala potencialmente ilimitada. Como um livro, um filme, um software ou outro produto em formato digital. E escalável é o ponto mais importante: a startup pode crescer sem precisar mudar o seu modelo de negócios. Crescer em receita, mas com custos crescendo mais lentamente. Naturalmente a gestão de uma startup também é diferente, com ferramentas próprias, visão e métodos que funcionem nesse ambiente de incerteza até que o modelo seja encontrado.

O investimento para startups é importante, pois sem capital de risco é muito difícil persistir na procura pelo modelo de negócios enquanto não existe receita. E após a comprovação de que ele existe e a receita começar a crescer, provavelmente será necessária uma nova leva de investimento para a startup se tornar uma empresa sustentável. Quando se torna escalável, a startup deixa de existir e dá lugar a uma empresa altamente lucrativa. Caso contrário, ela precisa reinventar-se ou enfrenta a ameaça de morrer prematuramente.

Normalmente são empresas de pequena dimensão, apesar de nem todas as pequenas empresas poderem ser consideradas startups (Ries, 2011). Uma startup é, no início de atividade, uma pequena ou microempresa necessariamente. Mas nem todas as pequenas ou micro- 
empresas são uma startup. Entretanto, ainda é bastante comum a confusão entre pequenas empresas e negócios com o significado atual de startups.

Claramente que os proprietários de pequenos negócios diferem de empreendedores no que diz respeito à sua capacidade de inovação, de julgamento, criação da procura, vontade de crescimento, assim como habilidade de gestão. Enquanto pequenas empresas se colocam de forma passiva em relação à procura, com pouco foco no crescimento do negócio e menor ainda em inovação, as startups trabalham para entender completamente a procura de forma a alavancar rapidamente as suas receitas e a entrega de valor percebido aos seus clientes e à sociedade.

No blog da WordPress.com refere-se que a startup é uma empresa que procura oferecer alguma solução, serviço ou facilidade até então inédita, que se tornou possível graças à Internet. Para uma melhor compreensão recorreram ao exemplo de duas empresas muito conhecidas, que iniciaram há relativamente poucos anos e que também foram startups. Os fundadores do Google perceberam que os mecanismos de busca na Internet de antigamente eram fracos e operados por seres humanos que jamais conseguiriam indexar todos os sites que surgiam. Ao entender a necessidade, desenvolveram o motor de busca Google depois de perceber que conheciam o suficiente para criar um algoritmo que fosse aprendendo cada vez mais. Deu certo e hoje grande parte do orçamento que se investe em publicidade na Internet vai para o Google. O Facebook, começou como uma rede social para estudantes, como outras que já apareciam também. Mas os fundadores souberam inovar, competir e crescer. Ao conquistarem uma enorme audiência, Facebook e Google lucram com a venda de anúncios.

O autor Eric Ries (2011) afirma que o valor criado pela startup não está no produto propriamente dito, mas sim nas pessoas e na organização que o criaram, não podendo, por isso, uma startup ser caracterizada pura e simplesmente pelo seu produto. Uma startup é uma organização com base tecnológica que ainda está a procurar o seu modelo de negócio e precisa ajustar o produto ao mercado. Neste processo, a 
startup atua num ambiente dúbio, deve apresentar uma inovação de produto, modelo de negócio ou algum diferencial no seu processo. Por serem promissoras, as startups são responsáveis por atrair diversos investidores que aproveitam para utilizar as ideias como uma forma de melhoria do seu próprio negócio, permitindo-lhes no aumento de visibilidade no mercado. Como o mercado de tecnologia está em alta, o crescimento de uma startup pode ser exponencial e muito rápido. $\mathrm{O}$ mesmo acontece com o seu valor de mercado.

Com base nas várias pesquisas realizadas, percebeu-se que a startup é um modelo de empresa jovem, embrionária ou ainda em fase de constituição, implementação e organização das suas operações, pode ser também uma empresa que ainda não iniciou a comercialização dos seus produtos e serviços, mas esteja em vias de realizá-lo.

Paul Graham co-fundador da maior aceleradora americana Y Combinator, expõe de forma clara esta visão. Para ele, uma startup é uma empresa concebida para crescer rápido. Ser recém-fundada não caracteriza em si mesmo construir uma startup. Nem é necessário para uma startup que se trabalhe com tecnologia, ou que utilize financiamentos de alto risco. A única coisa essencial é o crescimento. É importante perceber que as startups apresentam uma diferença intrínseca em relação a outras empresas, o fator velocidade de crescimento e escalabilidade. Ou seja, para crescer rapidamente é preciso que se construa algo que seja vendável para um grande mercado e a um grande número de clientes. Ter potencial de atingir (resolver um problema) um enorme número de indivíduos simultaneamente é uma das principais bases de uma startup que deseja ser rentável e lucrativa, além de desempenhar um papel relevante na sociedade.

Para terminar, as startups são diferentes das grandes empresas porque, enquanto as grandes empresas executam um modelo de negócios definido, as startups procuram um modelo de negócios. O fator "novidade" de uma startup, ou seja, fatores que se focam essencialmente no facto de estas empresas serem recentes no mercado, interessa por isso saber por quanto tempo uma empresa poderá ser considerada uma startup, pelo que, o período a considerar deverá incluir os primeiros seis anos de funcionamento de uma empresa, no 
entanto, este período de tempo ponderado varia de autor para autor. Há autores que consideram desde uma empresa recém-formada até uma com oito ou dez anos (Hayton, 2002; citado por Brigidi, 2009).

\section{Modelo Lean Startup}

Steve Blank foca a importância da experiência, das tentativas, falhas, adaptações e repetições na procura de um negócio adequado. Criador do movimento Lean Startup, estratégia que auxilia as startups a desenvolverem-se de forma mais eficiente, Eric Ries é uma figura emblemática neste âmbito.

Conforme mencionado anteriormente, uma startup é uma empresa concebida para criar novos produtos e serviços sob condições de incerteza extrema. A metodologia Lean Startup teve origem na experiência e consequente cansaço de Eric Ries e dos seus cofundadores em relação ao pensamento tradicional de como construir uma empresa.

Deparando-se com a desagradável realidade de que muitas das startups falham, o autor procurou alternativas ao pensamento tradicional, tentando melhorar a taxa de sucesso de produtos inovadores. Percebeu que fatores como: o fascínio de um bom plano, uma estratégia sólida e um estudo de mercado podem constituir um problema para estas novas empresas, pois a incerteza em que as startups operam é muito elevada, sendo o produto e os clientes uma incógnita.

Assim, juntamente com os seus cofundadores começou a defender que "o funcionamento das funções do negócio e do marketing de uma startup deve ser considerado tão importante como a engenharia e o desenvolvimento do produto e por isso merece uma metodologia igualmente rigorosa para o conduzir" (Ries, 2011: 11). Denominada de "metodologia de desenvolvimento do cliente" o autor ajudou na procura de inovações que dessem sentido à sua atividade como empreendedor. Neste contexto, e após um estudo profundo sobre uma nova produção de bens físicos, a produção Lean, surgiu o conceito de Lean Startup, que aplicava aquele pensamento ao processo de inovação. 
Citando o próprio autor: "A ideia Lean Startup transformou-se num movimento global. Milhares de empreendedores estão a aplicar os princípios da Lean Startup em todas as indústrias possíveis" (Ries, 2011: 13).

Ambicionando o sucesso, todos os empreendedores procuram descobrir "como construir uma organização sustentável em torno de um novo conjunto de produtos e serviços." Para Ries, "tudo o que é necessário é que mudemos a nossa forma de pensar coletiva sobre como o trabalho deve ser feito" (Ries, 2011: 278). Nas palavras do autor "A produção Lean redescobriu a sabedoria e espírito de iniciativa (...) e redirecionou a noção de Taylor de eficiência (...) ao aproximarse do organismo corporativo como um todo" (Ries, 2011: 276).

Considera-se que o trabalho da empresa pode ser analisado cientificamente e através de uma rigorosa abordagem experimental. Assim é possível compreender o que constitui desperdício, o que levou a erros e falhas, evitando a sua repetição, e ainda alterar o modo como se encara a inovação conquistando melhores resultados.

A este propósito Hart (2012) afirma que o uso do termo Lean é consistente com a filosofia de gestão do Sistema de Produção da Toyota e que neste contexto é uma abordagem que se esforça para minimizar o gasto de recurso em qualquer outra coisa que não seja criar valor para o cliente.

"Toda a inovação começa com uma visão", e a sua validação depende da construção de "um modelo comportamental de clientes" (Ries, 2011: 282). Em cada empreendimento as ideias e ambições dos fundadores são testadas em relação à realidade do mercado, constituindo aquele um verdadeiro "learning lab" (Bradberry, 2011: 125).

O método Lean Startup, concebido para ensinar como conduzir uma startup, baseia-se em cinco princípios. São eles: "os empreendedores estão em todo o lado, o empreendedorismo é gestão, a aprendizagem validada, construir-medir-aprender e contabilização da inovação" (Ries, 2011: 14-15). Nesta metodologia propõe-se aos empreendedores 
que avaliem o seu progresso de forma diferente, pela chamada "aprendizagem validada." Pretende-se eliminar o desperdício de recursos e tempo comum no empreendedorismo, transmitindo ao empreendedor orientação para tomar as melhores decisões nas diferentes áreas e em diferentes momentos. O objetivo de uma startup é encontrar a coisa certa para construir o que os clientes querem e pagam para ter, o mais rápido possível. A Lean Startup é uma nova forma de olhar para o desenvolvimento de produtos inovadores que enfatizam a rápida interação da informação do cliente, uma grande visão e grande ambição, tudo ao mesmo tempo.

$\mathrm{Na}$ metodologia Lean Startup todos os produtos, todas as características e campanhas de marketing, tudo o que se faz, são compreendidos como uma experiência concebida para conquistar a aprendizagem validada. Conduzida pela visão da startup, a experimentação visa descobrir como se constrói uma organização sustentável. Assim, o primeiro passo é decompor a grande visão nas suas partes componentes, a hipótese de valor e a hipótese de crescimento. A primeira vai testar se o produto ou serviço confere de facto valor para o cliente. A segunda testa como os novos clientes descobrem um produto ou serviço. Experiências adicionais permitem mais feedback, promovendo a aprendizagem.

Neste contexto, a produção de resultados negativos deve ser encarada de modo instrutivo, não como um sinal de fracasso, mas como um estímulo para a alteração da estratégia. Toda esta ideia de valorizar a informação real do presente, de avaliação do momento é explicitada por Ries ao mencionar que, "contrariamente ao planeamento estratégico tradicional ou ao processo de estudos de mercado, esta especificação terá por base o feedback sobre como funciona hoje em vez da antecipação de como poderá funcionar amanhã" (Ries, 2011: 67). Estas são ajudas essenciais, que permitem melhorias de processos e escolha das melhores soluções. Perceber quais são os pontos fortes e fracos, as oportunidades e ameaças de um negócio é essencial para um bom planeamento, um trabalho eficaz e uma evolução satisfatória. 


\section{O feedback e experimentação}

Comunicar a essência de um negócio recém-criado implica um conjunto de recursos limitados para enfrentar várias pressões: questões temporais, financeiras, de concorrência e de consciência da existência da marca. O autor do livro "Startup: An Insider's Guide to Launching and Running a Business", Kevin Ready, defende que qualquer empreendedor tem de estar preparado para enfrentar a fase de desconhecimento por parte do público em relação ao seu negócio. A indiferença do consumidor é uma realidade do mercado.

É na mudança desta situação que o empreendedor deve investir. Todo o esforço por detrás de um negócio deve ter como propósito chegar às pessoas, apresentar-lhes o produto ou serviço, fazer com que estas conheçam a marca e essencialmente que a procurem. O objetivo é o de construir algo com impacto, que solucione um problema e crie valor, e portanto, o foco no projeto que se pretende desenvolver é fundamental. $O$ processo é longo e exige persistência e determinação.

A entrada do empreendedor no mercado pode acontecer pelo aparecimento de uma ideia promissora em relação a determinado produto ou serviço, ou pela vontade de criar um negócio próprio, em que a escolha do que vender surge posteriormente. Se por um lado, uma ideia mais fraca pode ser suportada por um excelente planeamento e execução, por outro, um ótimo produto pode tornar-se um fracasso quando mal-executado. É necessário que o produto se insira na "verdade do mercado", o que significa tratar-se de um produto que resolva determinado problema do público, na medida em que um número significativo de pessoas pague por ele. Ter total domínio do produto ou serviço criado é fundamental na altura de entrada no mercado, pois permitirá proteger o negócio da concorrência que certamente surgirá.

No centro da metodologia Lean Startup encontra-se o chamado "circuito de reação construir-medir-aprender" (Ries, 2011: 77). Como esclarece Eric Ries, o objetivo é minimizar o tempo total desse circuito, pois aí encontra-se a verdadeira essência de gerir uma startup. Utilizando a aprendizagem validada, pretende-se perceber onde e 
quando investir energia, minimizando custos e tempo e acelerando os processos. Ries explica que "cada iteração de uma startup é uma tentativa de aumentar a velocidade do motor para ver se ele trabalha" (Ries, 2011: 78). As hipóteses a testar são a hipótese de valor e hipótese de crescimento, que depois de clarificadas levam à fase de construção do que o autor apelidou de "produto minimamente viável" (PMV).

Este PMV é a versão do produto que possibilita o funcionamento total do circuito construir-medir-aprender, com o mínimo de esforço e com o mínimo de tempo de desenvolvimento. É a versão mínima do produto, ou seja, antes de sair para o mercado com o produto completo com todas as funcionalidades, é preciso validar a sua ideia, a sua hipótese, a sua solução. Essa versão geralmente tem funcionalidades básicas. Se a ideia é muito complexa para ser desenvolvida, antes de entrar no desenvolvimento, deve-se lançar uma versão menor, ir para o mercado e através do feedback, descobrir se é realmente a solução de um problema. O autor aponta os erros de algumas empresas que investiram alto em projetos que deixaram de ser a solução e que não tem uma funcionalidade real.

A atividade fundamental de uma startup é transformar ideias em produtos, medir como os clientes reagem, e aprender se é o caso de testar hipóteses ou insistir. Todos os processos de startups bemsucedidas devem ser voltados para acelerar este ciclo de feedback.

\section{Lean Branding}

Lean Branding é uma temática recente, logo, a bibliografia existente, artigos científicos, blogs e sites ainda apresentam informação escassa e, portanto, limitadora para expandir e cruzar conhecimento. Uma temática sobretudo focalizada para o empreendedor do seculo XXI, que crie um negócio online, ou não. Contudo, e condicionados pelas mudanças tecnológicas, dinâmicas de mercado, novas metodologias de gestão, os empreendedores não podem deixar de lado o mundo virtual. Muitas vezes a primeira e senão definitiva impressão da marca começa ali. 
É graças a um universo paralelo, que se tem acesso a múltiplas e novas oportunidades. Hoje ensina-se branding sem secretismo, os processos foram simplificados e é quase "just do it". Aprender hoje está à distancia de um clique.

Embora o Lean Startup seja focado no desenvolvimento de produtos e gestão de negócios, os seus princípios podem ser aplicados às marcas também. O ciclo construir-medir-aprender é completamente válido e facilmente aplicado à metodologia Lean Branding. Foi o que demostraram os autores Laura Busche e Jeremiah Gardner.

Assim como para a construção de um produto, também se pode construir a marca à medida que a empresa cresce e refiná-la para encontrar a solução que vá de encontro às preferências dos clientes. Ser "lean" significa entender que não é grave não ter um produto perfeito logo no seu lançamento, isso até é o mais sensato. A marca não vai e não deve ser perfeita quando se inicia os negócios (Busche, 2014).

A este propósito Eric Ries (2014) refere no prefácio que escreveu no livro Lean Branding, "assim como os produtos nunca estão verdadeiramente acabados, as marcas também devem estar comprometidas com a adaptação e a evolução. As empresas não podem permitir que as suas marcas estagnem ou pensem nelas como um conjunto de recursos. Em vez disso, os gestores devem construir marcas camaleónicas que se adaptem às necessidades e desejos em constante mudança do consumidor, pondo hipóteses à prova e usar o que aprenderam com a repetição e a adaptação", Eric Ries in Lean Branding (2014).

As marcas hoje são melhores se gestores, empreendedores entenderem essas mudanças e aprenderem com elas. As marcas Lean têm conversas, não monólogos (Busche, 2014: 218). As empresas não possuem marcas. As pessoas possuem marcas. Esta é a revolução. As pessoas não querem falar com empresas sem rosto. Elas querem falar com as pessoas que estão dentro das empresas (Gobé; 2002). 
O Lean Branding é uma nova metodologia de gestão da marca para empresas ágeis. Este método trata de construir marcas dinâmicas uma vez que, como refere a autora de nada vale ficar parado no mercado enquanto a noção dos consumidores sobre quem eles são, muda constantemente. As marcas hoje estão em melhor situação porque procuram entender essas mudanças e, como referido, aprender com elas através de um processo de co-criação.

Lean Branding é uma abordagem muito interessante para o desenvolvimento de marca que indica o caminho para criar, comunicar e vender uma marca, medindo continuamente o desempenho (Busche, 2014).

Trata-se da gestão de uma marca em que uma organização e audiência alcançaram uma relação simbiótica, em torno de um valor comum sem criar qualquer desperdício de marca. No Lean Branding fala-se de inovação da marca. Uma metodologia otimizada para a formação de uma marca disruptiva e centrada em torno da experimentação, interação e eliminação de resíduos de marca. Lean branding fornece uma estrutura escalável para ciclos contínuos de desenvolvimento e aprimoramento através de aprendizagens validadas e desenvolvimento de clientes reais (Gardner, 2014).

O mesmo autor defende que atualmente vivemos numa era de rápidas transformações, portanto, é importante analisar como é que a inovação de marca transforma as organizações, construindo valor e criando clientes apaixonados. Milhares de startups, empresários e empresas corporativas lutam para construir relacionamentos apaixonados com o público. Marca significa uma relação (Gardner, 2014).

Enquanto The Lean Startup e The Lean Entrepreneur fornecem técnicas para criar produtos inovadores, a marca Lean concentra-se no desenvolvimento de relacionamentos inovadores. O desenvolvimento da marca é (ou deveria ser) um processo baseado em evidências onde se depreende uma combinação de símbolos, história e estratégia que representará a oferta num mercado cada vez mais competitivo (Busche, 2015). Os símbolos, a história e estratégia que a autora ensina a 
construir destinam-se a orientar os clientes para este caminho de conversão.

\section{Plano de Comunicação para uma Startup}

Bazzo, Domakoski y Arauz (2012), afirmam que a comunicação, desde o início, foi sentida como uma necessidade de negócio para os sócios de uma startup que ajudaram. Sendo que as primeiras ações tomadas no que toca à comunicação da empresa foi um website institucional, atuação em redes sociais, e ações de assessoria de imprensa, ao mesmo tempo procuraram um profissional qualificado que desenvolvesse a comunicação da empresa.

Os autores apontam três macro etapas principais para a criação de um plano de comunicação da startup em causa, (1) desenvolvimento de diagnóstico, (2) delimitação de estratégia de ação e (3) definição de mecanismos de monitorização e avaliação de resultados. Afirmam também que o sucesso do planeamento depende da sinergia entre esses pontos.

Ermano (2013), afirma ainda ter ajudado muitas startups por meio de comunicação $360^{\circ}$. Com modelos corretos de comunicação é possível atrair ainda mais a atenção dos investidores, público-alvo, parceiros, e dos media. Depois de vários erros e acertos, o autor diz que para alavancar uma startup com um plano de comunicação, não pode ser um plano comum, tradicional como é normal aplicar as empresas com alguns anos no mercado. Isso porque as startups têm um crescimento muito rápido e um plano habitual não acompanha esse crescimento e dinamismo. Então o autor propõe numa primeira fase identificar os principais pontos do modelo de negócio, antes de falar em comunicação. Isso porque os planos podem conduzir a startup para diversos caminhos. Dependerá, ainda, do perfil dos sócios, caso tenha.

Após verificar a estrutura, produto ou serviço e canais de distribuição, é hora de pensar no plano de comunicação. O próximo passo está relacionado à imagem institucional da empresa. A pergunta que se impõe é como se pretende ser conhecido no mercado, uma boa apresentação impressionará os clientes. Este é um fator que muitos 
novos empreendedores, principalmente os gestores de startups se esquecem e erram ao fazerem o plano de comunicação. Deve-se levar também em conta os investidores, eles podem chegar por vários caminhos.

Uma ferramenta amplamente difundida para a comunicação com formadores de opinião é a imprensa. Muitos clientes também chegam através da exposição nos mais variados media. Além disso, estas ações fortalecem a imagem institucional da marca ou produtos e geram visibilidade.

Os conselhos partilhados pelo autor são de crucial importância, deve apostar-se na pesquisa de mercado e conceito da marca. É essencial conhecer a visão, missão e valores da empresa. Esta é a primeira parte do trabalho na comunicação institucional. Criação de processos para gerar contatos eficientes com investidores, parceiros ou profissionais do setor. O segundo conselho está ligado ao planeamento que liga a gestão à comunicação. Para atingir metas é importante analisar em que ponto a startup está e onde pode chegar.

Chegou, portanto, o momento de iniciar a criação de uma identidade unificada para a empresa. Definir como fazer a apresentação dos produtos e serviços, qual o conteúdo do website e outros canais de comunicação é crucial. Importa também analisar que tipo de estudos de mercado é que existem.

O passo seguinte relaciona-se com a criação de planos de comunicação e gestão, para o ano em questão e, no máximo, um plano ousado para o ano seguinte. Isto porque as startups são dinâmicas e precisam de flexibilidade para atender aos mercados, garantindo aos empreendedores e investidores sucesso nos mercados de atuação. $\mathrm{O}$ terceiro conselho do autor, está ligado à gestão e relações institucionais via imprensa. Escolhido os canais, o tipo de comunicação e os objetivos, é o momento de iniciar as ações de comunicação mais abertas e direcionadas aos diversos púbicos, planeados pelos consultores, assessores e os gestores das empresas.

Já é possível comunicar à sociedade, aos mercados, aos parceiros e, principalmente, aos formadores de opinião de massa (os jornalistas). 
Uma importante área da comunicação nas estratégias de comunicação institucionais de startups é a assessoria de imprensa. A consultoria é realizada por jornalistas e relações públicas com bons relacionamentos e networking através de opinion makers nas diversas redações jornalísticas do país. Trata-se de profissionais que conhecem os perfis dos jornalistas e outros profissionais das redações editoriais que acompanham os movimentos sociais e auxiliam os profissionais de comunicação a identificarem as tendências, novidades e temas que gerem valores ao país e aos seus mercados.

A exposição opinativa nos diversas medias (jornais, internet, TVs e rádio) tende a atrair a atenção de investidores, clientes e impressões na opinião pública/privada para empreendedores e consequentemente para os seus negócios e produtos.

Por último, Ermano (2013), aconselha a ampliação de mercados e novos negócios. Estabelecidos no mercado, é altura de criar uma cultura de informação e notícias dentro do projeto, fazendo com que as relações institucionais e públicas estejam impecáveis para os públicos conquistados, por meio da comunicação social. É através destas "medidas" que se terá a oportunidade de receber feedbacks espontâneos sobre a atuação da empresa no mercado, se informar sobre concorrentes e logicamente haverá mais hipóteses de conseguir espaços disputados na imprensa sobre o empreendedorismo.

Em conclusão, entende-se que a comunicação deve ser muito mais dinâmica do que nas empresas com mais anos de vida no mercado. Contudo, deve-se manter pontos comuns ao plano comunicação "tradicional". Pontos como, diagnóstico, estratégia, monitorização e avaliação apontadas pelos autores Bazzo, Domakoski y Arauz (2012).

\section{A Comunicação nas Redes Sociais das empresas emergentes}

A sociedade moderna está a produzir, a um ritmo alucinante, uma quantidade de novos conhecimentos e tecnologias, fruto da crescente evolução científica e de uma maior globalização. Nesta mudança, social e tecnológica, a comunicação, eficiente e precisa, assume um papel de destaque no desenvolvimento e sustentação das empresas. 
No atual contexto de mercado, a comunicação tornou-se um recurso estratégico para qualquer empresa. Esta, para ser competitiva, é obrigada a saber gerir a comunicação de forma a criar valor acrescentado e promover o desenvolvimento do negócio.

Ao contrário da maioria dos mass media (como a televisão, rádio, imprensa escrita, etc.), o marketing digital proporciona uma oportunidade menos dispendiosa, mais imediata e até direta de promover negócios numa comunidade global. As redes sociais, por sua vez comunidades online geralmente gratuitas, são o exemplo perfeito de uma ferramenta que permite ao empreendedor comunicar de forma rápida e simples, facilitando inclusive uma resposta imediata.

A este propósito afirmam Kimura, Teixeira, Godoy (2004) que as redes sociais possibilitam ao empreendedor contatos, ampliar as possibilidades de encontro de oportunidades de carreira e negócios, além de se configurar como uma forma para as empresas alcançarem competitividade nos mercados por meio de complexo ordenamento de relacionamentos, em que firmas estabelecem inter-relações.

Além do mais, influenciam o comportamento de indivíduos e grupos, onde a ação humana é afetada pelas relações sociais em que os agentes estão imersos. Essas interações sociais aprimoram ou restringem o acesso a recursos, pois, incorporando capital social, geram externalidades como conhecimentos sobre o comportamento de outros agentes em relação ao mercado, como preços e tecnologias; e sobre o benefício da ação coletiva. Portanto, considerando que a rede social se baseia nas relações interpessoais, acredita-se que ela é um elemento presente e determinante, capaz de influir no comportamento competitivo das organizações.

O novo consumidor das redes sociais, formador de opinião compartilha na rede as marcas de sua preferência, e até produz conteúdo com sugestões para a escolha de um nome para um novo produto, sugestão para um novo serviço ou indicação de eventos. Vivemos na era da co-criação, agora é o consumidor que diz qual é o melhor produto ou serviço, e não o produtor. 
Os negócios já não são como antes, a Internet veio para criar um novo mundo dos negócios, uma nova forma de produzir, vender e inovar. Para reforçar este pensamento, recorre-se ao exemplo das empresas que vendem máquinas fotográficas que tiveram que olhar para o negócio com uma nova abordagem estratégica porque os telemóveis são uma ameaça ao negócio, as edições dos jornais tiveram que se reinventar, os negócios redefinem-se para acompanhar as inovações, as mudanças provocadas pelo mundo digital.

Com esta realidade nasce o empreendedor digital, os novos criadores do "mundo.com", da revolução digital, da educação digital, do trabalho em casa, na rua, no hotel ou em qualquer lugar conectado em rede. $\mathrm{O}$ empreendedor digital caracteriza-se como um especialista em inovação, e que entende de economia criativa, identidades digitais, pode ser um produtor de website, criador de conexões e interações com as marcas e empresas nas redes sociais.

Hoje em dia quem não está nas redes sociais é como se não existisse. E há quem não esteja apenas presente, como quem possua conta em vários serviços. As redes sociais permitem aos seus membros conectarem-se com pessoas próximas ou com qualquer outra pessoa do outro lado do mundo. Oferecem, aos seus utilizadores, uma grande liberdade para se expressarem.

Não é por acaso que o marketing se tenha virado para as redes sociais. O novo relatório da Universidade de Massachusetts-Boston, apontou que a maioria das empresas da Fortune 500, classificação das 500 maiores corporações em todo o mundo, é adepta de redes sociais como Facebook, Twitter, Google+, Instagram, YouTube, Foursquare e Pinterest. As startups parecem ter uma relação ímpar com as redes sociais. Esta realidade permitiu às empresas dar um salto quantitativo e qualitativo nas suas estratégias. $O$ que no princípio gerou certa inquietação entre as marcas deu agora lugar a uma nova forma de desenhar a comunicação.

Hoje em dia é impensável não ter presença em plataformas digitais. $\mathrm{O}$ relatório "La sociedad de la información en España" deixa claro que mais de metade dos utilizadores de Internet desconfiam das marcas que não 
têm presença nas redes sociais. Os utilizadores de hoje em dia já se podem considerar experts nos mais diversos temas. Têm tanta informação à sua disposição e podem partilhar de forma tão rápida e simples as suas experiências e opiniões que se torna evidente que têm uma vantagem face às gerações anteriores.

A tendência para a partilha de informação em massa é indiscutível. $O$ último estudo elaborado pelo Trusted Shops, em colaboração com a Alpha Research, afirma que $96,5 \%$ dos utilizadores que fazem compras online procuram comentários de outros consumidores antes de comprar algum produto na Internet. É por isso que a estratégia nas redes sociais procura constantemente a satisfação dos utilizadores e ainda ter um canal de comunicação bidirecional, onde os seguidores encontram uma marca próxima, amável, inovadora e sempre disposta a ouvir os conselhos e necessidades da comunidade.

É importante inspirar a audiência com os conteúdos publicados, originar uma conversa de qualidade e criar uma afinidade emocional, são só alguns exemplos do que se deve procurar quando a empresa se conecta com os seguidores. E sobretudo, é bastante importante construir uma comunidade fiel à marca onde se faça com que os usuários se sintam os principais fãs ao receberem de forma exclusiva conteúdos únicos e inovadores. Nunca se obteve o feedback dos clientes de forma tão direta como agora, o que permite reagir rapidamente na melhoria dos produtos e serviços.

Como refere Túñez, "as comunidades virtuais adquirem um papel estratégico na comunicação porque possibilitam o estabelecimento de relações estreitas entre as organizações e os seus stakeholders, baseadas no compromisso e na relação interpessoal. Porém, não pode ser esquecido que o importante não é ter presença na Internet, mas sim conseguir ser parte da conversação" (Túñez; 2016: 14).

A razão pela qual os empreendedores valorizam as redes sociais é precisamente porque as redes sociais correspondem, dão visibilidade sem custos, colocam-nas em contacto com o mundo em poucos segundos. Porque não exigem nada de volta, apenas conteúdos de qualidade e a manutenção da relação de qualidade com o cliente. 
Porque são novas, atrativas, sonhadoras e vistas pela ala empresarial mais conservadora como sinónimo de incerteza e risco.

As redes sociais tornaram-se, portanto, uma importante ferramenta de marketing. Nesta perspetiva, Coulter e Roggeveen (2012), destacam que cada vez mais as empresas estão a voltar-se para as redes sociais online como local importante para trabalhar o marketing. Isto porque, segundo Rocha et al (2011), as empresas podem utilizar os medias sociais como instrumento para segmentar as suas campanhas de acordo com o perfil dos usuários e comunidades existentes nas redes. Dessa forma, os medias sociais passaram a fazer parte da estratégia de comunicação das empresas.

As redes sociais online vieram mudar a relação dos utilizadores não só com a Internet, mas também com as empresas. Uma panóplia de startups surge para explorar o potencial destas redes e iniciam o seu ciclo de vida através das redes sociais online. Segundo um estudo efetuado na Universidade de Lisboa, Instituto Superior de Economia e Gestão, precisamente sobre startups que iniciaram a sua atividade nas redes sociais, conclui-se que as principais razões que levaram as startups a utilizarem as redes sociais como impulsionadores do negócio são a facilidade de disseminação de informação, maximizar a proximidade com o cliente, baixos custos associados à utilização das redes sociais online como meio de ação e alcançar uma visibilidade comparável à das grandes empresas sem grandes custos.

O estudo baseou-se numa metodologia qualitativa, mais concretamente no estudo de caso de quatro startups Portuguesas. Relativamente às principais ações utilizadas para lançar a marca salienta-se que as que mais se destacaram foram: partilha de imagens alusivas ao produto, partilha de vídeos e incentivo dos clientes à partilha das suas experiências com a marca. Os exemplos dados são pouco representativos de uma realidade tão extensa, no entanto, constituem fonte de conhecimento e de demonstração prática.

Ainda há a considerar um outro estudo publicado na revista Comunicação \& Informação, da Universidade Federal de Goiás-Brasil, sobre as startups e o consumo de comunicação, as possibilidades por 
variáveis de influência em redes sociais digitais. Participaram na pesquisa oito startups, de diferentes regiões do país, cujas atividades envolvem a criação de apps, softwares, lojas virtuais, interfaces gráficas, alojamento de sites, sistemas web, geotecnologia, eventos, além do desenvolvimento de soluções inovadoras em diversas plataformas e tecnologias. As empresas estão no mercado há menos de cinco anos, possuem de dois a nove funcionários e todas utilizam pelo menos três redes sociais digitais, sendo as mais citadas o Facebook, Instagram, Linkedin, Twitter e WhatsApp.

Conclui-se que as redes sociais digitais se apresentam como eficiente ferramenta para conectar empresas e clientes. Contudo, para entender e apontar as motivações que levam os empreendedores a utilizarem esta ferramenta, procurou-se perceber as razões e finalidades para o uso das redes digitais. As razões mais mencionadas foram a divulgação da marca, produtos e serviços da empresa; agilidade, velocidade e eficiência no processo de comunicação; localização, captação e retenção de clientes; facilidade de acesso e espaço nos medias; interatividade com os clientes; abrangência e efeito viral das publicações; baixo custo; vendas; credibilidade e benchmarking. Destas, entendem-se como variáveis de influência: divulgação, velocidade, clientes (internautas ou usuários), interatividade, abrangência e custo. É possível inferir que as startups utilizam as redes sociais como uma ferramenta de comunicação e canal de relacionamento com os clientes, fatores cruciais para a imagem da startup no mercado.

Para as startups estudadas, as estratégias de comunicação nas redes sociais digitais estão inseridas no plano de marketing da empresa e consistem, basicamente, na análise e diagnóstico do ambiente virtual, planeamento das ações e conteúdo, publicações e monitorização dos medias. Além disso, as empresas concordam que houve uma melhoria significativa no contato com os clientes e na imagem da empresa após ingresso nas redes. E complementam que, o que era uma forma de chamar atenção de clientes e investidores, agora faz parte das atividades quotidianas de comunicação das empresas.

No que se refere à análise e diagnóstico do ambiente virtual, destacamse: análise do perfil dos clientes, utilização de personas e benchmarking. A partir daí as empresas planeiam o conteúdo das publicações, voltadas 
para divulgação da marca, produtos e serviços, procurando adaptar as campanhas ao perfil dos clientes, às novidades e tendências do mercado. Neste ponto, ainda há quem defina a frequência dos posts e os temas abordados.

O pesquisador e professor americano, Mikotaj Jan Piskotiski, que estudou mais de 50 empresas em diversos setores económicos, encontrou um erro muito comum; estas empresas utilizam as suas estratégias digitais para plataformas sociais disseminando mensagens comerciais ou procurando o feedback dos clientes. Segundo o autor, o principal interesse do público das redes sociais não é receber mensagens comerciais, e sim conhecer e fazer relacionamentos com outras pessoas, não com empresas. Por isso, a abordagem nas redes sociais tem que ser diferente, a empresa não deve partir de imediato para a venda do produto ou serviço. Existem muitas oportunidades vinculadas às necessidades e motivos que levam o indivíduo a viver sempre em grupos, desde os tempos das "tribos", hoje, temos a criação das redes segmentadas, que são uma representação dos relacionamentos entre os grupos com interesses específicos. O principal objetivo das redes sociais de nicho é conectar pessoas, nos chats, fóruns, comunidades, canais de vídeo, simpósios online e outros. A estratégia correta é focar na comunidade e não na ferramenta, tentar descobrir o que é mais útil e acessível para o nicho. E além de tudo, estimular o engagement, a motivação dos membros na troca de informações e experiências.

A verdade é que a literatura e estudos empíricos sobre esta nova realidade empresarial emergente e ainda em afirmação é praticamente nula. Existem alguns autores que se debruçaram sobre o assunto, mas a informação é reiterada de autor para autor. A recente existência e o forte interesse do capital especulativo fizeram com que a parte prática se tenha desenvolvido muito além da teórica e, por isso, o conteúdo ainda precisa ser mais estudado. 


\section{Referencias}

Bazzo, J.; Domakoski, M.S. y Arauz, R.A.P.; (2012). Planejamento estratégico e comunicação organizacional para uma empresa de internet: o caso da plataforma Agenda Fácil. Dito efeito IE.BN 1984-2376. Disponível em: http://revistas.utfpr.edu.br/ct/de/index.php/Ditoefeito/articl e/view/18.

Blanck, Steve (2013). Why the Lean Start-Up Changes Everything. Harvard Business Review.

Blanck, Steve e Ries, Eric (2012). The Lean Startup: Low Burn by Design not Crisis. Maples Investments.

Bradberry, John (2011), "6 Secrets to Startup Sucess - How To Turn Your Entrepreneurial Passion Into a Thriving Business", United States of America: Amacom.

Brigidi, Gabriel Mombach (2009). Criação de conbecimento em Empresas Start-up de alta tecnologia. Universidade Federal do Rio Grande do Sul, Escola de Administração, Programa de Pós Graduação em Administração - Mestrado em Administração.

Busche, Laura (2015). Lean Branding. Creating Dynamic Brands to Generate Conversion. O'Reilly Media, Inc.

Coulter, K.; Roggeveen, S. A. (2012). Like it or not. Management Research Review, Vol. 35 Iss 9 pp. 878 - 899.

Ermano, Thiago (2013). O poder da comunicação no inicio de uma Startup. Baguete. Disponível em: http://baguete.com.br/artigos/1208/thiagoermano/22/03/2013/o-poder-da-comunicacao-no-inicio-deuma-startup.

Gardner, J.; Cooper, B. (2014). Entrepreneur's Guide To The Lean Brand: How Brand Innovation Builds Passion, Transforms Organizations and Creates Value. Kindle Edition

Gobe, M. (2002). A Emoção das Marcas. Conectando Marcas às Pessoas. Livraria Cultura

Gitahy, Y. (2011). O que é uma Startup? Empreendedor Online Empreendedorismo na Internet e negócios online,2011. Disponível em Disponível em: http://exame.abril.com.br/pme/noticias/o-que-e-uma-startup. 
Hart, Mark A. (2012). The Lean Startup: How Today's Entrepreneurs Use Continuous Innovation to Create Radically Successful Businesses. The Journal of Product Innovation Management, 29(3):506-510.

Kimura, H.; Teixeira, M. L. M.; Godoy, A. S.(2004). Redes sociais, valores e competências: simulação de conexões. Revista de Administração Contemporânea - RAC, Edição Especial, 42-57.

Ries, Eric (2011). The Lean Startup. New York: Crown Business. Rocha, T. V., Jansen, C., Lofti, E, y Fraga, R R (2011). O uso das redes sociais na construção do relacionamento com clientes: um estudo de caso múltiplo no Brasil. In: Encontro da Anpad. Rio de Janeiro. Anais.

Túñez López, M y Costa-Sánchez, C. (Eds.), (2016). Interação organizacional na sociedade em rede. Os novos caminhos da comunicação na gestão das relações com os públicos. Cuadernos Artesanos de Comunicación, $\mathrm{n}^{\circ}$ 102, (13-20). La Laguna (Tenerife): Latina.

Toledo, Marcelo (2012). Plano de Negócios para Startups. E-book. Disponível em: https://pt.scribd.com/document/337082132/Plano-deNegocios-Para-Startups-Marcelo-Toledo\# 



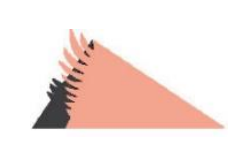

\section{Los autores y las autoras}

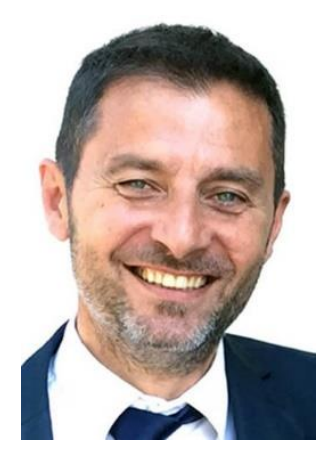

JosÉ MIGUEL TúÑEZ LóPEZ

Universidade de Santiago de Compostela España

miguel.tunez@usc.es

Doctor en Periodismo por la Universidad Autónoma de Barcelona y profesor de Comunicación Organizacional y de Estrategias de Comunicación en la Universidade de Santiago de Compostela. Consultor. Miembro del Grupo de Investigación Novos Medios. Premio Nacional de Periodismo Reina Sofía.

scholar.google.es/citations?user $=\mathrm{fGFou0MAAAAJ \& hl=es \& oi=aO}$ orcid.org/0000-0002-5036-9143

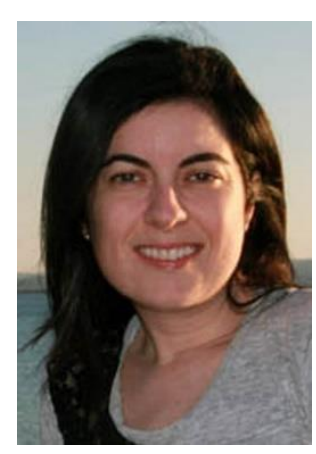

\section{CARMEN Costa-SÁNCHEZ}

\section{Universidade da Coruña - España}

carmen.costa@udc.es

Doctora en Comunicación por la USC y profesora de Comunicación Corporativa en la Universidade da Coruña. Co-autora de Comunicación Corporativa. Claves y Escenarios (ed. UOC) y de Estrategias de Comunicación multimedia (ed. UOC). Miembro del Grupo de Investigación Cultura y Comunicación interactiva.

scholar.google.es / citations?user=b--o414AAAAJ\&hl=es orcid.org/0000-0001-8154-9537 


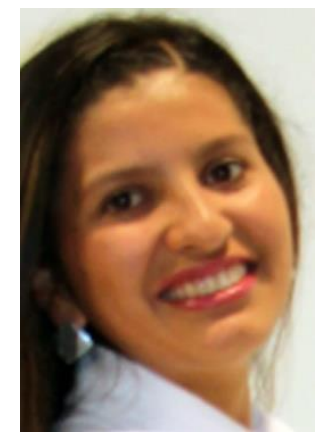

KARE CESIBEL VALDIVIEZo ABAD

Universidad Técnica Particular de Loja -

Ecuador

Universidade de Santiago de Compostela-

España

kcvaldiviezo@utpl.edu.ec

Profesora en el Departamento de Ciencias de la Comunicación y pertenece al grupo de investigación Comunicación Estratégica de la Universidad Técnica Particular de Loja. Doctoranda en Comunicación e Información Contemporánea en la Universidade de Santiago de Compostela. Máster en Investigación de la Comunicación en la Universidad de Navarra. Licenciada en Comunicación Social. scholar.google.es $/$ citations? ? orcid.org/0000-0003-4816-4752

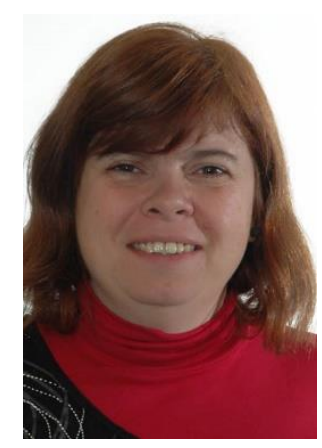

\section{BELÉN PUEBLA-MARTÍNEZ Universidad Rey Juan Carlos - España belen.puebla@,urjc.es}

Profesora e investigadora de la Universidad Rey Juan Carlos. Doctora en Ciencias de la Comunicación. Licenciada en Periodismo y en Comunicación Audiovisual. Es especialista en el estudio de la ficción televisiva española, en el estudio de los métodos analíticos de investigación en comunicación social y en didácticas innovadoras para la enseñanza de la lengua, entre otras líneas de investigación.

http://orcid.org/0000-0002-1481-4238

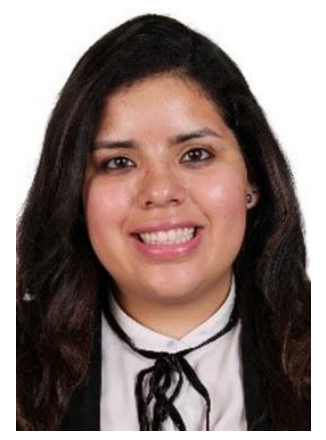

VALERIE GESSEY BÁEZ ERAZO Corte Nacional de Justicia - Ecuador valerie.baez@,cortenacional.gob.ec

Analista de la Unidad de Relaciones Públicas y Comunicación Social de la Corte Nacional de Justicia 
de Ecuador. Colabora como Community Manager en el manejo de redes sociales de microempresas. Es Magister en Gestión Estratégica de la Información y el Conocimiento en las Organizaciones por la Universitat Oberta de Catalunya.

orcid.org/0000-0002-5441-4992

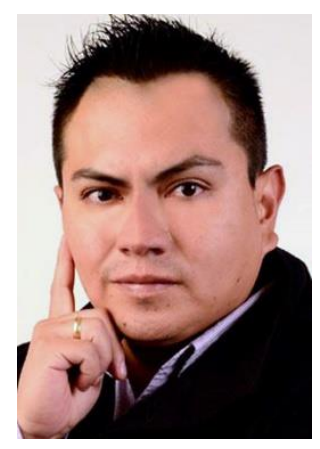

\section{DIEGO APOLO BUENAÑO}

Universidad Nacional de Educación de Ecuador

(UNAE) - Ecuador

diego.apolo@unae.edu.ec

Docente investigador en la Universidad Nacional de Educación - UNAE en Ecuador y Docente invitado en Posgrado de la Universidad de Las Américas de Ecuador. Investigador Acreditado y Categorizado por la Secretaría de Educación Superior, Ciencia, Tecnología e Innovación - Senescyt. Ha participado en diferentes espacios nacionales e internacionales de Investigación, Innovación y Desarrollo. Revisor en revistas indexadas en Scopus y Latindex.

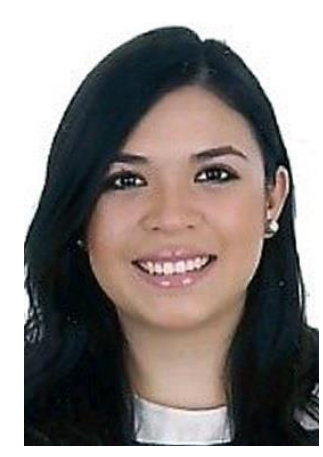

GABRIELA ESTEFANÍA PASQUEL Municipio del Distrito Metropolitano de Quito Ecuador

gabriela.pasquel@quito.gob.ec

Socio Organizativa y Gestora de la Comunidad de la Unidad Especial Regula Tu Barrio adscrita a la Secretaría de Coordinación Territorial y Participación Ciudadana del Municipio del Distrito Metropolitano de Quito. Es Licenciada en Comunicación Corporativa por la Universidad de las Américas, Quito. Ha laborado en organizaciones nacionales e internacionales. 


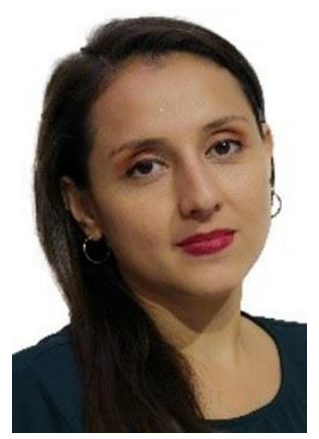

\section{LIZETH MICHELLE PAUKER}

Yasuní Medios - Ecuador

lpauker@yasunimedios.com

Jefe de Relaciones Públicas del municipio de Francisco de Orellana - Ecuador. Reportera de Yasuní Medios, radio y televisión pública de este cantón. Es licenciada en Comunicación Corporativa por la Universidad de Las Américas, Ecuador. Ha publicado artículos en revistas de reconocido prestigio internacional.

http://orcid.org/0000-0003-4488-5667

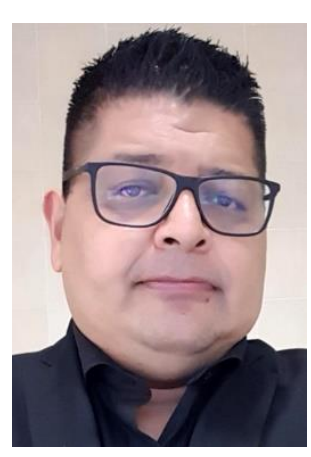

\section{ROBERTO ALEJANDRO LÓPEZ NOVELO} Universidad Anáhuac México - México

robertoa.lopez@anahuac.mx

Doctor en Ciencias Políticas y Sociales con orientación en Comunicación por la Universidad Nacional Autónoma de México (UNAM). Profesor-Investigador del Centro de Investigación para la Comunicación Aplicada (CICA) de la Facultad de Comunicación de la Universidad Anáhuac, México. Desde el 2005 profesor en diversas Instituciones de Educación Superior.

\section{orcid.org/0000-0003-0978-9784}

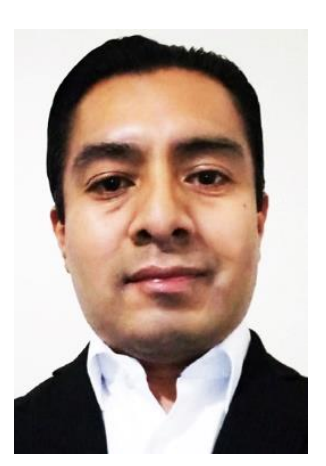

\section{RAÚL SANTOS MORALES}

Universidad Anáhuac México - México

raul.santos@anahuac.mx

Licenciado en Publicidad, maestro en Diseño Gráfico y doctor en Comunicación Aplicada. Desde 2009, se ha dedicado a la docencia en diferentes instituciones educativas y actualmente se desempeña como profesor-investigador en el Centro de Investigación para la Comunicación Aplicada (CICA) de la Universidad Anáhuac México.

orcid.org/0000-0002-6128-9616

scholar.google.com.mx/citations?user=D6gbgj0AAAAJ\&hl=en 


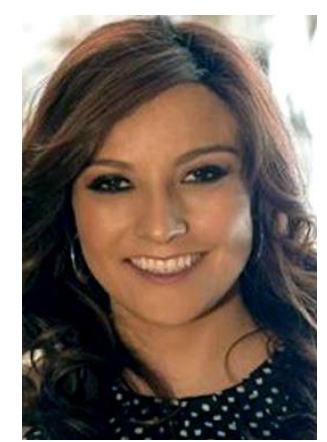

\section{VERÓNiCA Altamirano}

Universidad Técnica Particular de Loja - Ecuador vpaltamirano@utpl.edu.ec

Doctora por la Universidad Santiago de Compostela (España). Docente principal de la Universidad Técnica Particular de Loja, coautora de libros internacionales, de artículos en revistas científicas y divulgativas. Es parte del grupo de investigación Comunicación Estratégica de la Universidad Técnica Particular de Loja. Maestría en Comunicación e Industrias Creativas por la USC, Diplomada en Comunicación Organizacional, Diplomada en Comunicación para el Desarrollo y licenciada en Comunicación Social por la Universidad Técnica Particular de Loja (Ecuador).. $\underline{\text { scholar.google.es/citations? } \mathrm{user}=\text { YLgkGTQAAAAJ\&hl=es }}$

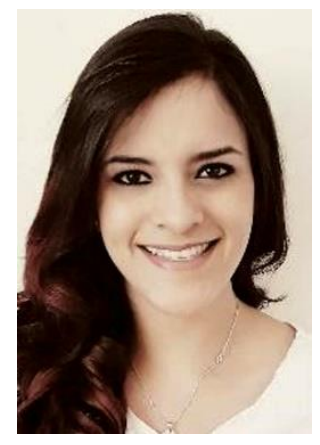

\section{FABIANA ALTAMIRANO}

Universidade de Vigo - España

maltamirano@alumnos.uvigo.gal

Ingeniera en Administración de Empresas por la Universidad Técnica Particular de Loja (Ecuador). Maestranda de la Universidad de Vigo en Comunicación en Medios Sociales y Creación de Contenidos Digitales. Advanced Refinement level en la Académie Linguistique Internationale (Montreal - Canadá).

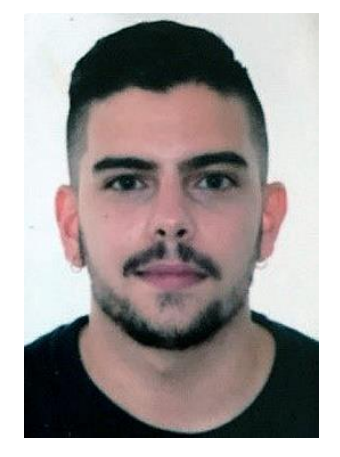

\section{FRANCISCO DE ANDRÉS HUERTAS Universidad Complutense de Madrid - España frdeandres@gmail.com}

Graduado en Periodismo por la Universidad Complutense de Madrid. Empezó sus estudios en Información y Documentación en la Universidad Complutense de Madrid y más tarde cambió por el Periodismo debido a su pasión por la tecnología y las nuevas formas de creación de 
contenido y comunicación. Ha sido colaborador y presentador en diversos programas de radio en Inforadio Complutense, y como redactor y Community Manager en la revista Padel Absolute. Cuenta con un canal en Youtube (Fran de Andrés Huertas), donde comparte su pasión por la creación y edición de video e imagen.

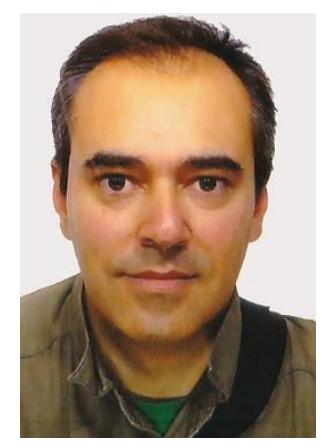

\section{SERGIO MENA MUÑOZ Universidad Complutense de Madrid - España smenamun@,ccinf.ucm.es}

Doctor en Periodismo por la Universidad Complutense de Madrid. Doctorando en Historia Contemporánea por la Universidad Autónoma de Madrid y Licenciado en Comunicación Audiovisual y en Periodismo por la Universidad Nebrija de Madrid. Periodista en diversos medios de comunicación tanto de la rama audiovisuales (Televisión Española, Canal 7 TV, Grupo Intereconomía), prensa escrita o internet (Grupo Negocios). Socio fundador de la agencia de comunicación CBC Onlinekeepers, especializada en el entorno 2.0.

scholar.google.com/citations?user $=\mathrm{c} 0 \mathrm{~A} 1 \mathrm{zxEAAAAJ \& hl=es}$ orcid.org/0000-0001-6121-4991

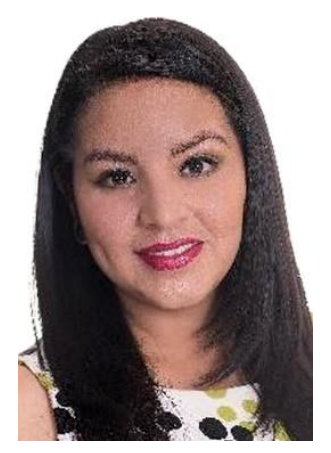

VANESSA DUQUE Universidad Nacional de Loja - Ecuador Universidade de Santiago de Compostela vanessa.duque@unl.edu.ec

Docente de la Universidad Nacional de Loja y la Universidad Técnica Particular de Loja. Doctoranda en Comunicación e Información Contemporánea de la Universidad Santiago de Compostela, Magíster en Dirección de Comunicación Empresarial e Institucional y Licenciada en Ciencias de la Comunicación Social. Trabaja e investiga en el ámbito de la comunicación corporativa.

orcid.org/0000-0003-0102-2829

scholar.google.es/citations?user=Ai1 A9sAAAAJ\&hl=es 


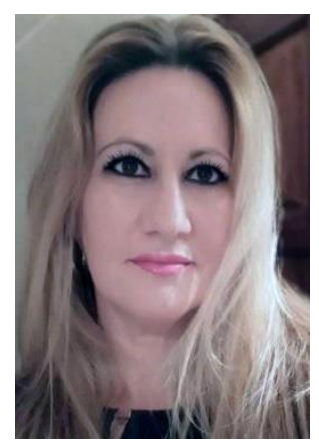

\section{PAULA OLIVEIRA}

Universidade de Santiago de Compostela España

paula.r.oliveira@sapo.pt

Docente de Marketing e Relações Públicas. Formadora e consultora na área de Marketing e Branding. Doutoranda en Comunicación e Información Contemporánea, Universidade de Santiago de Compostela; Mestrado Gestão de Marketing, IPAM (Instituto Português de MarketingUniversidade Europeia); Licenciatura em Marketing, ISAG (Instituto Superior de Administração e Gestão). Coordenadora de projectos de empreendedorismo-Junior Achievement Portugal. 